UNIVERSIDADE DE SÃO PAULO

FACULDADE DE FILOSOFIA, LETRAS E CIÊNCIAS HUMANAS

DEPARTAMENTO DE FILOSOFIA

PROGRAMA DE PÓS-GRADUAÇÃO EM FILOSOFIA

\title{
Elaine Camunha
}

A função da religião civil e sua relevância na teoria política do Contrato Social de Jean-Jacques Rousseau 


\section{UNIVERSIDADE DE SÃO PAULO \\ FACULDADE DE FILOSOFIA, LETRAS E CIÊNCIAS HUMANAS \\ DEPARTAMENTO DE FILOSOFIA \\ PROGRAMA DE PÓS-GRADUAÇÃO EM FILOSOFIA}

A função da religião civil e sua relevância na teoria política do Contrato Social de Jean-Jacques Rousseau

Elaine Camunha

Dissertação apresentada ao Departamento Filosofia da Faculdade de Filosofia, Letras e Ciências Humanas da Universidade de São Paulo, para a obtenção de título de Mestre em Filosofia.

Orientador: Prof. Dr. Rolf Kuntz

São Paulo

2008 
Dedico este trabalho a meu amigo Pedro Monticelli, por muitas razões. 


\section{Agradecimentos}

Ao Cá, por todo incentivo, apoio, carinho e paciência;

A meu pai, pelo imenso apoio e compreensão;

Às minhas duas grandes e queridas amigas Daniela Reis e Luanda Mottas, pelo imenso incentivo e apoio;

À minha mãe, prima Anna, avó, madrinha, sogro e sogra, por todo carinho e apoio;

À CAPES;

A meu orientador, prof. Rolf Kuntz, por toda contribuição e ajuda;

Aos professores Chiappin e Maria das Graças, pelas observações no exame de qualificação;

A meus grupos de estudo;

Ao colega Thomaz Kawauche, pela gentileza em fornecer-me textos, livros e indicações bibliográficas;

A Marcos Balieiro, por ter gentilmente traduzido o resumo da dissertação;

Às funcionárias do Departamento de Filosofia, especialmente à Maria Helena, pela atenção e ajuda. 


\section{Resumo}

Camunha, Elaine. A função da religião civil e sua relevância na teoria política do Contrato Social de Jean-Jacques Rousseau. 2008. 82 f. Dissertação (Mestrado) Faculdade de Filosofia, Letras e Ciências Humanas. Departamento de Filosofia, Universidade de São Paulo, São Paulo, 2008.

O objetivo deste trabalho é mostrar, como indica o título, a função da religião civil e sua relevância na teoria política do Contrato Social de Jean-Jacques Rousseau. Para dar conta de nossa proposta, reconstruímos o cenário teórico do Contrato, apontamos o lugar que a religião aí ocupa e mostramos que ela é peça essencial para a realização dos objetivos de uma sociedade bem constituída, segundo os padrões rousseaunianos.

Historicamente, segundo Rousseau, a religião sempre foi uma peça importante da política e um componente fundamental daquelas sociedades caracterizadas pela estreita coesão dos cidadãos e pelo vigor do espírito público. A manutenção do Estado ideal que Rousseau constrói depende da existência de uma religião, mas esta deve ser puramente civil. Seus dogmas devem ser simples e destinados a fomentar as virtudes necessárias à cidadania, isto é, à concretização de uma liberdade fundada na supremacia da vontade geral e na irrestrita dedicação à pátria.

Palavras-chave: Rousseau; Filosofia Política; religião; poder; liberdade. 


\begin{abstract}
Camunha, Elaine. The function of civil religion, as well as its relevance, in the political theory of Jean-Jacques Rousseau's Social Contract. 2008. 82 f. Thesis (Máster Degree) - Faculdade de Filosofia, Letras e Ciências Humanas. Departamento de Filosofia, Universidade de São Paulo, São Paulo, 2008.

This work aims, as we can tell by its title, at showing the function of civil religion, as well as its relevance, in the political theory of Jean-Jacques Rousseau's Social Contract. To fulfill our purpose, we reconstruct the theoretical scenery of the Contract, with the objective of pointing out the place which is there attributed to religion, as well as showing it is essential for the fulfillment of the objectives of a well built society, according to Rousseaunian standards.

Historically, according to Rousseau, religion has always been an important part of politics, and a fundamental component of the societies marked by a strict cohesion of the citizens and by the vigor of the public spirit. The maintenance of the ideal State built by Rousseau depends on the existence of a religion, but this must be purely civil. Its dogmas must be simple and meant to foment the virtues which are necessary to citizenship, i. e., the concretizing of a freedom which is founded in the supremacy of the general will and in the unbounded dedication to one's country.
\end{abstract}

Key-Words : Rousseau, Political Philosophy, religion, power, freedom. 


\section{Sumário}

Introdução................................................................................................................................ 08

Capítulo I - Contexto teórico em que a religião civil opera

1.1. Introdução............................................................................................................... 11

1.2. A concepção de homem - bondade natural e liberdade........................................12

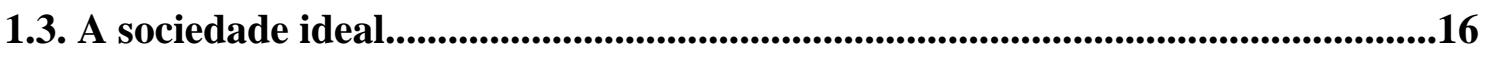

1.4. Vontade geral versus vontade particular e amor da ordem versus amor do bem-estar material

Capítulo II - A religião civil

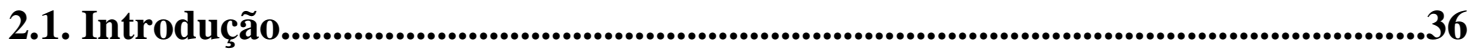

2.2. A religião civil no Contrato Social..............................................................37

2.3. A religião natural...................................................................................................52

2.4. A religião em outros escritos de Rousseau..................................................63

Capítulo III - Crítica de Rousseau ao cristianismo

3.1. A posição de Rousseau frente ao cristianismo. .69

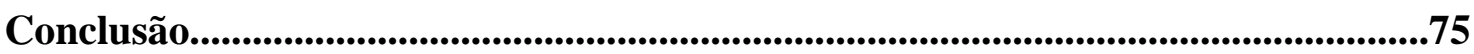

Bibliografia..............................................................................................................................................79 


\section{Introdução}

Ao discutir o espírito das antigas instituições, no capítulo II de suas Considerações sobre o Governo da Polônia, Jean-Jacques Rousseau remete o leitor, por meio de uma nota entre parênteses, ao fim do Contrato Social. O leitor cuidadoso poderia fazer a ligação por si mesmo, mas a remissão explícita é especialmente importante para o estudioso do pensamento rousseauniano. Confirma o valor atribuído pelo autor à religião civil, tema do capítulo final do Contrato: não se trata de um apêndice descartável, de um adendo menor de última hora, mas de um componente essencial do poder de Estado - pelo menos, de um Estado constituído para durar e para garantir, ao longo de muito tempo, a liberdade característica de um ser racional.

O pleno exercício da racionalidade e dos atributos a ela associados só se torna possível, no entanto, como conseqüência de uma longa transformação. Rousseau atribui à natureza do homem a liberdade e a bondade, mas esta não é, originalmente, uma bondade moral, já que não é raciocinada - o homem no estado de natureza só tem a razão potencialmente. No estado de natureza, contudo, essa inclinação para o bem ainda que anterior à moralidade - é suficiente para garantir a paz e a felicidade.

Toda a natureza é regida por certas regras. Assim, se o homem é bom é porque ele age segundo uma determinada regra, ainda que isso não implique conhecimento dessa regra nem escolha de sua parte, pois é limitado ao instinto. Rousseau denomina essas regras primitivas, ou princípios inerentes à alma humana, que são anteriores à razão, amor de si e piedade. O primeiro é um guia que leva o homem a alcançar tudo o que é necessário à sua conservação; o segundo modera sua ação para que ele se limite a satisfazer suas necessidades.

A passagem do estado de isolamento, que caracteriza o primeiro estado de natureza, para o estado de convivência entre os homens - segundo estado de natureza, causado por catástrofes naturais - gera uma mudança na ordem das coisas. Os homens, agora com muitas paixões, são guiados por elas. É verdade que a razão começa a se desenvolver, já que a condição para que ela se desenvolva é a vida em sociedade; porém, quando o homem pode, por meio dela, alcançar aquilo que possibilitaria uma condição justa e pacífica, que a é lei natural, as paixões falam tão alto que essa perde sua força. O que se passa a ter, portanto, é um estado de plena desordem em que todos estão ameaçados. 
Esse quadro não só explica a origem de um poder que se forma legitimamente e depois se transforma em poder arbitrário, mas ele também funciona como ponto de partida - uma suposição de Rousseau -, isto é, como um problema inicial que deverá ser solucionado. Um poder precisa ser criado para que a situação se estabilize e todos vivam tranquilamente. No entanto, é necessário que esse poder garanta a liberdade do homem - atributo de sua natureza que ficou comprometido na vida em sociedade, pois antes ele não dependia de ninguém e também ninguém necessitava de seus serviços, e agora escraviza e é escravizado.

O que Rousseau se propõe a examinar no Contrato Social, portanto, é se, por meio de uma modificação na sociedade, o homem pode aproximar-se daquilo que ele era. A desordem é fruto da vida em sociedade; logo, somente tentando consertá-la é que se poderá restabelecer a ordem.

O primeiro passo para a reconstrução da sociedade é que cada um aliene sua força e seu poder individuais à sociedade toda. A partir daí, cria-se um poder, do qual todos farão parte. As ações passam a ser reguladas pela vontade geral, expressa na forma de leis. A vontade geral visa exclusivamente o bem comum, que é alcançado por uma operação do entendimento. O indivíduo que agir visando um interesse particular, portanto contrariando a lei, que é a única que pode garantir sua liberdade no Estado, será punido, já que a lei civil - ao contrário da lei natural - prevê sanção.

Os homens já viviam em sociedade - ainda que aquela fosse marcada pela guerra - antes de formar o Estado, mas a razão ainda não havia se desenvolvido totalmente. Como, então, os homens poderiam conhecer as regras de conduta que deveriam guiar suas ações? Isso é tarefa para um Legislador. Para ser bem-sucedido em sua função, porém, deverá recorrer à religião. Somente utilizando uma linguagem religiosa poderá persuadir - já que não pode convencer - os homens do caráter justo das leis, fazendo com que esses não só a aceitem como a cumpram.

A religião incita o amor aos deveres. A consciência, que opera em conjunto com a razão, também tem essa função de provocar um certo amor no indivíduo de forma que ele seja levado a cumprir seus deveres. A religião tem mais força, porém, do que a razão e a consciência, pois ela, assim como a lei civil, prevê uma sanção, ainda que possa acontecer somente em uma outra vida; também tem mais força pelo respeito que impõe.

Rousseau propõe para o Estado, no entanto, uma religião civil. O corpo político não pode adotar uma outra religião, por exemplo, o cristianismo. Entre os motivos pelos 
quais ele recusa essa religião histórica está o fato de ela conter uma moral que é incompatível com a moral defendida pelo Estado.

Se neste trabalho tentamos reconstruir todo esse percurso, foi com o objetivo de situar a religião civil neste cenário teórico que envolveu não só o Contrato mas também o Discurso sobre a desigualdade e o Emílio. Se a proposta era, como indica o título, mostrar a função que a religião civil tem, e provar sua relevância na teoria política do Contrato Social, não podíamos ter deixado de apresentar o conteúdo que forma essa teoria. 


\section{Capítulo I}

\section{Contexto teórico em que a religião civil opera}

\subsection{Introdução}

É “na política que Jean-Jacques encontra a solução para os problemas que sua concepção de homem lhe põe, pois não é senão por uma renovação total da sociedade que se poderá restabelecer o homem em uma condição não igual mas ao menos análoga àquela que ele usufruía na origem”" .

Tendo em vista a afirmação acima, este primeiro capítulo foi divido da seguinte forma: dedicamos uma primeira parte à apresentação da concepção rousseauísta de homem; uma segunda à resposta que Rousseau dá para o problema e uma terceira e última que se detém em um ponto específico contido na segunda parte.

Tentamos reunir e examinar as principais passagens do Discurso sobre a origem e os fundamentos da desigualdade entre os homens que nos fornecem uma noção clara do que Rousseau entende por natureza humana. Também reproduzimos trechos de outras obras do autor que correspondem ao conteúdo analisado.

Num segundo momento, expusemos o cenário - é nele que se apresenta a “renovação total da sociedade”, à qual Sérgio Cotta se refere - de condições ideais que devem existir para que uma sociedade política seja bem organizada e justa e para que o indivíduo que dela faça parte exerça plena liberdade. Tal cenário é apresentado no Contrato Social, mas também aí identificamos partes de outros escritos que têm relação com o conteúdo exposto.

A terceira parte ocupa-se com um exame mais detido do conflito entre vontade geral e vontade particular e o paralelo deste - que tentamos traçar - com o amor da ordem e o amor do bem-estar material. Achamos que seria relevante essa discussão já que tal conflito pode repercutir de forma negativa na estrutura ideal da "nova" sociedade.

\footnotetext{
${ }^{1}$ Cotta, Sergio, «Théorie Religieuse et Théorie Politique chez Rousseau », p.172: « (...) dans la politique que Jean-Jacques trouve la solution des problèmes que sa conception de l'homme lui posait, car ce n'est que par un renouvellement total de la societé qu'on pourra rétablir l'homme dans une condition non pas égale mais tout au moins analogue à celle dont il jouissait à l'origine (... ).»
} 


\subsection{A concepção de homem - bondade natural e liberdade}

No Contrato Social Rousseau faz algumas afirmações que pressupõem argumentos já desenvolvidos no Discurso sobre a desigualdade, por exemplo:“(...) todos, tendo nascido iguais e livres, só alienam sua liberdade em proveito próprio.”2 Precisamos saber como o filósofo chega à conclusão de que certos atributos constituem a natureza do homem, de que certo direito natural lhe é conferido, para entendermos por que, na constituição da sociedade civil, isso deve ser levado em consideração, e sirva, ainda, para limitar o poder soberano ${ }^{3}$.

Recorrendo a um método de descrição histórico-hipotético Rousseau expõe, no segundo Discurso, o seguinte quadro: O estado de natureza é pacífico e marcado pela vida isolada e pelo perfeito equilíbrio entre as necessidades do homem e os recursos dos quais ele dispõe: “(...) o homem não pode desejar senão as coisas que se encontram em seu meio físico imediato, já que são as únicas que se apresentam. Ele não terá, portanto, senão desejos físicos e desejos muito simples. 'Seus desejos não ultrapassam suas necessidades físicas, os únicos bens que ele conhece no universo são a comida, uma fêmea e o repouso.’” ${ }^{4}$ Dessa forma, ele não depende de outros homens, somente das coisas $^{5}$, e é nisso que consiste sua liberdade, uma das marcas de sua essência Rousseau, afastando-se da definição tradicional de homem como um animal racional, diz que o que o diferencia dos animais é sua qualidade de agente livre e a perfectibilidade $^{6}$; sua razão não é desenvolvida - pois somente em sociedade é que ela

\footnotetext{
${ }^{2}$ Rousseau, J-J. Do Contrato Social, p.24.

${ }^{3}$ Derathé, R. Roussseau et la science politique de son temps, p.168-169: «Non seulement l'autorité souveraine ne doit rien prescrire qui soit contraire aux préceptes de la loi naturelle, mais les hommes n’ont accepté de se soumettre à cette autorité qu’à seule fin de mieux s’assurer la jouissance paisible de leurs droits individuels. L'État ne doit donc pas disposer de plus de pouvoir qu'il n'en faut pour cette fin, et les droits naturels de l'homme constituent une limite à la souveraineté de l'État. »

${ }^{4}$ Durkheim, É. Montesquieu et Rousseau, p. 122: «(...) l'honnne ne peut désirer que les choses qui se trouvent dans son milieu physique immédiat, puisque ce sont les seules qu'il se représente. Il n'aura donc que des désirs physiques et des désirs tres simples. 'Ses désirs ne passent pas ses besoins physiques, les seuls biens qu'il connaisse dans l'univers sont la nourriture, une femelle, et du repos’ ».

5 Idem, p.123: “(...) dans cette situation, l'homme est en équilibre avec son milieu, parce qu'il est purement physique et ne dépend alors que du milieu physique et de lui seul. La nature qui est en lui correspond nécessairement à celle qui est au dehors. L'une est l'image de l'autre. Les conditions mêmes d'un désaccord manquent completement. »

${ }^{6}$ Rousseau, J.-J. Discurso sobre a desigualdade, p.243: “ Não é, pois, tanto o entendimento quanto a qualidade de agente livre possuída pelo homem que constitui, entre os animais, a distinção específica daquele. (...) Mas, ainda quando as dificuldades que cercam todas essas questões deixassem por um instante de causar discussão sobre diferença entre o homem e o animal, haveria uma outra qualidade muito específica que os distinguiria e a respeito da qual não pode haver contestação - é a faculdade de
} 
pode se desenvolver - , mas há dois princípios anteriores a esta, o amor de si e a piedade, que têm sua fonte no instinto, que servem como guia de sua conservação e adaptação ao meio ambiente e aos seres que dele fazem parte.

O homem, por ter sido criado por Deus, é originariamente inocente e mesmo bom $^{7}$, isso significa, portanto, que a bondade natural também é um atributo de sua natureza: "O princípio fundamental de toda a moral, sobre o qual refleti em todos os meus escritos, e que desenvolvi nesse último - ele se refere à Profissão de fé - com toda clareza de que era capaz, é que o homem é um ser naturalmente bom, que ama a justiça e a ordem, que não há nenhuma perversidade originária em seu coração, e que os primeiros impulsos da natureza são sempre corretos.”8

Como a conservação, no estado de natureza, é “quase sua única preocupação”, o homem fará o que for necessário para garanti-la, inclusive comprometer a de outrem. Não se deve deduzir daí, no entanto, ao contrário do que acabamos de afirmar, que ele seja mau, ou, no caso de conseguir o que necessita sem a ninguém precisar prejudicar, seja bom. É por instinto que o homem age, por isso que a bondade é amoral: "Parece, a princípio, que os homens nesse estado de natureza, não havendo entre si qualquer espécie de relação moral ou de deveres comuns, não poderiam ser nem bons nem maus ou possuir vícios e virtudes, a menos que, tomando estas palavras num sentido físico, se considerem como vícios do indivíduo as qualidades capazes de prejudicar sua própria conservação, e virtudes aquelas capazes de em seu favor contribuir, caso em que se poderia chamar de mais virtuosos àqueles que menos resistissem aos impulsos simples da natureza." 10

Quando o homem passa de um estado de quase isolamento, em que tudo o que era necessário à sua manutenção estava ao seu alcance, para um outro de convivência permanente é que a razão, antes presente apenas potencialmente no homem, é ativada, ainda que esse processo se dê muito lentamente ${ }^{11}$. A partir daí podemos falar em moral,

aperfeiçoar-se, faculdade que, com o auxílio das circunstâncias, desenvolve sucessivamente todas as outras e se encontra, entre nós, tanto na espécie quanto no indivíduo (...).”

${ }^{7}$ Cotta, Sergio, «Théorie Religieuse et Théorie Politique chez Rousseau », p.178: «C'est ainsi que, 'sortant des mains de l'Auteur des choses', l'homme est naturellement bon (...). »

${ }^{8}$ Rousseau, J.-J. Carta a Christophe de Beaumont, p. 48.

${ }^{9}$ Rousseau, J.-J. Discurso sobre a desigualdade, p.242.

${ }^{10}$ Idem, p.251.

${ }^{11}$ Rousseau, J.-J. Carta a Christophe de Beaumont, p.63: « (...) a razão é uma das aquisições do homem, e mesmo uma das mais lentas. » Passagem da Nova Heloísa, reproduzida por Derathé em Le rationalisme de Jean-Jacques Rousseau, p.9, que também expressa isso: “ 'De toutes les instructions propres à l’homme, celle qu'il acquiert le plus tard et le plus difficilement est la raison même.’” 
em virtude ${ }^{12}$, mas, ao mesmo tempo, podemos falar em aumento das necessidades, em paixões desenfreadas e, resultante disso, não só a maldade, mas também a escravidão. As necessidades excessivas são o resultado das luzes do homem que, por sua vez, são fruto da vida em sociedade. Sou mau quando satisfaço as minhas necessidades às custas de outrem; sou escravo não somente quando sou subjugado, mas também quando dependo de outros para me satisfazer: “O que se crê senhor dos demais, não deixa de ser mais escravo do que eles.”13

No início do capítulo II do livro I do Manuscrito de Genebra, intitulado "Da sociedade geral do gênero humano”, encontramos uma passagem que reforça o argumento que acabou de ser apresentado: “A força do homem é de tal modo proporcionada às suas necessidades naturais e a seu estado primitivo que, por pouco que mude esse estado e aumentem suas necessidades, para ele se torna necessária a assistência dos semelhantes, e, quando, por fim, os desejos alcançam a natureza inteira, o concurso de todo o gênero humano mal basta para apaziguá-los. Por isso, as mesmas causas que nos tornam maus, também nos fazem escravos e, depravando-nos, submetem-nos.” 14 Se no estado de natureza só dependo das coisas para minha conservação e não encontro grandes dificuldades para consegui-las, no estado social minhas necessidades, ultrapassando em muito aquelas naturais, me tornam dependente dos outros homens, o que pode me levar à escravidão - ou ao vício, pois farei qualquer coisa para alcançar o que desejo - , assim como aqueles que de mim dependem podem se tornar escravos.

Isso dito, fica evidente que para Rousseau não devemos procurar a causa do mal moral fora do homem mas no próprio homem: "Homem, não mais procures o autor do mal; esse autor és tu mesmo. Não existe outro mal além do que fazes ou do que sofres, e

\footnotetext{
${ }^{12}$ Rousseau, J-J. Manuscrito de Genebra, p.172: « (...) se essa independência perfeita, essa liberdade sem regras permanecesse unida à antiga inocência, sempre existiria um vício essencial, prejudicial ao progresso de nossas melhores faculdades, a saber: a ausência, entre as partes, da ligação que constitui o todo. A terra ver-se-ia cheia de homens entre os quais não haveria quase nenhuma comunicação; tocarnos-íamos em alguns pontos, sem nos unirmos por nenhum deles; cada qual permaneceria isolado entre os demais, cada qual pensaria somente em si mesmo; não poderia desenvolver-se nossa compreensão, viveríamos sem nada sentir, morreríamos sem haver vivido; toda a nossa felicidade consistiria somente em não conhecer a própria miséria; em nossas ações não haveria quer bondade nos corações, quer moralidade nas ações, e nunca teríamos experimentado o mais delicioso sentimento da alma - o amor pela virtude."

${ }^{13}$ Rousseau, J-J. Do Contrato Social, p.22. Também trecho do Discurso sobre a desigualdade, p.267: “(...) o homem, de livre e independente que antes era, devido a uma multidão de novas necessidades passou a estar sujeito, por assim dizer, a toda a natureza e, sobretudo, a seus semelhantes dos quais num certo sentido se torna escravo, mesmo quando se torna senhor: rico, tem necessidade de seus serviços; pobre, precisa de seu socorro, e a mediocridade não o coloca em situação de viver sem eles.”

${ }^{14}$ Rousseau, J-J. Manuscrito de Genebra, p.171.
} 
ambos vêm de ti. O mal geral só pode estar na desordem, e vejo no sistema do mundo uma ordem que não se desmente."15 A “véritable 'dénaturation' "16 do homem é provocada pelas luzes e pela sociedade. Tornando-se mau ao desviar-se da natureza, daquilo que ela prescreve, o homem rompe com a ordem do mundo.

Se a liberdade é um dos elementos que diferenciam o homem do animal, ela foi dada a ele não para que escolhesse o seu mal: "Sem dúvida não sou livre para não querer meu próprio bem, não sou livre para querer meu mal, mas a minha liberdade consiste justamente no fato de eu só poder querer o que é conveniente para mim, ou que considero como tal, sem que nada de alheio a mim me determine.” ${ }^{17}$ As luzes levam o homem a conhecer novos objetos; ele pode desejá-los ou rejeitá-los, conforme sua conveniência ou não conveniência. Se escolhe algo que é nocivo, certamente é acreditando no contrário.

Se somos levados, no segundo Discurso, do conjetural - possível origem da escravidão e do vício - ao histórico ${ }^{18}$, no Contrato parte-se, da mesma forma, do hipotético, mas para se chegar ao ideal, a um modelo que possa ser utilizado para avaliar se uma sociedade é bem organizada e justa.

A liberdade é inerente à natureza humana. Ora, mas o que vemos é o oposto disso, isto é, o homem escravizado: “O homem nasce livre, e por toda parte encontra-se a ferros."19 Se no Discurso sobre a desigualdade Rousseau mostra de onde adveio tal mudança, no Contrato Social ele afirma ignorá-la ${ }^{20}$. O que Rousseau se propõe a examinar, agora, não é mais como se chegou a uma tal situação, mas como a passagem do estado de natureza para o estado civil pode ser legítima. Está preocupado em estabelecer "uma regra de administração legítima e segura, tomando os homens como são e as leis como podem ser." 21

\footnotetext{
${ }^{15}$ Rousseau, J.-J. Emílio, p.398. Na Carta a Voltaire, p.123, encontramos um trecho que reforça essa idéia: "Não vejo como se possa buscar a fonte do mal moral em outro lugar que não no homem livre, aperfeiçoado, portanto corrompido (....).”

${ }^{16}$ Cotta, Sergio, «Théorie Religieuse et Théorie Politique chez Rousseau », p.171.

${ }^{17}$ Rousseau, J.-J. Emílio, p.395-396.

${ }^{18}$ A sociedade que Rousseau lá descreve não é senão a sua, a que tem sob seus olhos: "Considerando a sociedade humana de modo calmo e desinteressado, a princípio ela só parece mostrar a violência dos homens poderosos e a opressão dos fracos (...).” Rousseau, J.-J. Discurso sobre a desigualdade, p.231. Na tentativa de explicar como se chegou a tal ponto é que, então, o filósofo recorre à hipótese, ainda que acrescente alguns fatos para reforçar seus raciocínios.

${ }^{19}$ Rousseau, J-J. Do Contrato Social, p.22.

${ }^{20}$ Idem.

${ }^{21}$ Ibidem, p.21.
} 
Se foi a sociedade que corrompeu o homem ${ }^{22}$, não é senão nela, contudo, que devemos buscar a solução: “(...) longe de pensarmos que não existe para nós virtude e bondade e que o céu nos abandonou, sem recursos, à depravação da espécie, esforcemo-nos por retirar do próprio mal o remédio que deverá curá-lo. Por meio de novas associações corrijamos, se possível, o defeito da associação geral.” ${ }^{23}$ É tendo isso em vista que Sergio Cotta afirma ser o pensamento de Rousseau caracterizado por um primado do político ${ }^{24}$.

Seguindo o objetivo que foi apresentado na Introdução deste capítulo, tentaremos mostrar agora em que consiste a "renovação total da sociedade" lá mencionada. Tal renovação deve ser caracterizada pela supremacia total da sociedade, e com isso do Estado, sobre o indivíduo ${ }^{25}$.

\subsection{A sociedade ideal}

Supondo os homens em uma situação de igualdade ${ }^{26}$, já que a preservação de todos está ameaçada e eles não mais podem recorrer ao uso da força, uma vez que "os obstáculos prejudiciais à sua conservação no estado de natureza sobrepujam, pela resistência, as forças de que cada indivíduo dispõe para manter-se nesse estado” ${ }^{27}$, “o gênero humano”, conclui Rousseau, “se não mudasse de modo de vida, pereceria.”28 Diante desse cenário ${ }^{29}$, o estabelecimento de um poder faz-se necessário, mas não se

\footnotetext{
${ }^{22}$ Rousseau, J-J. Cartas a Malesherbes, Carta 2, in Carta a Christophe de Beaumont e outros escritos sobre a religião e a moral, p.24: "Senhor, se algum dia pudesse escrever a quarta parte do que vi e senti sob essa árvore, com que clareza teria mostrado todas as contradições do sistema social, com que força teria exposto todos os abusos de nossas instituições, com que simplicidade teria provado ser o homem bom naturalmente e apenas por causa dessas instituições os homens tornaram-se maus.”

${ }^{23}$ Rousseau, J-J. Manuscrito de Genebra, p.176. A esse respeito, vale aqui o comentário de Ernest Cassirer: «"(...) o homem deve sim se transformar no seu próprio salvador e, no sentido ético, no seu criador. Em sua forma até agora existente, a sociedade causou as mais profundas feridas à humanidade, mas somente ela é que também pode e deve curar tais feridas. Desde então recai sobre ela o peso da responsabilidade.” A questão Jean-Jacques Rousseau, p.74

${ }^{24}$ Cotta, Sergio, «Théorie Religieuse et Théorie Politique chez Rousseau », p.172.

25 Idem.

${ }^{26}$ Embora a explicação do que seja essa "igualdade" venha logo em seguida, vale aqui um reforço. Nesse caso ela consiste no fato de todos, sem exceção, estarem ameaçados. Há os que correm risco por nada possuírem, e os que têm algumas ou muitas coisas podem ser surpreendidos a qualquer momento. O rico esmaga com facilidade um particular, mas "sendo ele próprio esmagado por grupos de bandidos (...).”Rousseau, J-J. Discurso sobre a desigualdade, p.268.

${ }^{27}$ Rousseau, J-J. Do Contrato Social, p.31.

${ }^{28}$ Idem, p.31.

${ }^{29}$ Esse cenário corresponde ao apresentado no segundo Discurso, p.268: “A sociedade nascente foi colocada no mais tremendo estado de guerra; o gênero humano, aviltado e desolado, não podendo mais
} 
pode perder de vista que o que o interesse prescreve - que é justamente a necessidade de um poder que regule as ações humanas e com isso se restabeleça o equilíbrio, neste caso, o social - deverá ser unido àquilo que o direito permite, “a fim de que não fiquem separadas a justiça e a utilidade.” ${ }^{30}$ Isso significa que a liberdade e a igualdade deverão ser garantidas na passagem para o estado civil, deverão ser compatíveis com a autoridade que irá se formar.

A liberdade - assim como a força - é um instrumento primordial da conservação do homem $^{31}$ e ela não pode subsistir sem a igualdade ${ }^{32}$. Rousseau explica o que entende por esta última: “(...) não se deve entender por essa palavra que sejam absolutamente os mesmos os graus de poder e de riqueza, mas, quanto ao poder, que esteja distanciado de qualquer violência e nunca se exerça senão em virtude do posto e das leis e, quanto à riqueza, que nenhum cidadão seja suficiente opulento para poder comprar um outro e não haja nenhum tão pobre que se veja constrangido a vender-se; o que supõe, nos grandes, moderação de bens e de crédito e, nos pequenos, moderação da avareza e da cupidez." ${ }^{33}$ Este trecho esclarece, portanto, por que a liberdade pressupõe a igualdade. Se um cidadão possuir muitos bens materiais ele pode escravizar um outro que possui pouco ou até mesmo nada, e esse, por encontrar-se nessa condição, pode não ter alternativa senão vender-se. A desigualdade, portanto, gera a escravidão. E isso não só com respeito à riqueza, como mostra Rousseau, mas com respeito ao poder, que não deve ser arbitrário, mas que deve, ao contrário, basear-se na lei - da qual iremos tratar mais adiante.

Já que a força ${ }^{34}$ não pode estabelecer o direito ${ }^{35}$, deve haver algum poder legítimo ao qual sejamos obrigados a obedecer, não por imposição, mas por dever.

voltar sobre seus passos nem renunciar às aquisições infelizes que realizara, ficou às portas da ruína por não trabalhar senão para sua vergonha, abusando das faculdades que o dignificam.” Se nesta obra Rousseau lança mão desta suposição na tentativa de apontar a origem do poder arbitrário que se instalou naquela sociedade, no Contrato ela serve para justificar de onde surge a necessidade das instituições políticas, mas tal suposição será o contraponto da sociedade ideal.

${ }^{30}$ Rousseau, J-J. Do Contrato Social, p.21.

${ }^{31}$ Idem, p.32.

${ }^{32}$ Ibidem, p.66.

${ }^{33}$ Ibidem, p.66-67.

${ }^{34}$ Ibidem, p.25: "Ceder à força constitui ato de necessidade, não de vontade; quando muito, ato de prudência".

${ }^{35}$ Ibidem, p.25: “Suponhamos, por um momento, esse pretenso direito. Afirmo que ele só redundará em inexplicável galimatias, pois, desde que a força faz o direito, o efeito toma lugar da causa - toda força que sobrepujar a primeira, sucedê-la-à nesse direito. Desde que se pode desobedecer impunemente, torna-se legítimo fazê-lo e, visto que o mais forte tem sempre razão, basta somente agir de modo a ser o mais forte. Ora, que direito será esse, que perece quando cessa a força? Se se impõe obedecer pela força, não se tem necessidade de obedecer por dever, e, se não se for mais forçado a obedecer, já não se estará mais obrigado a fazê-lo". 
Portanto, precisamos encontrar uma “ 'forma de associação que defenda e proteja a pessoa e os bens de cada associado com toda a força comum, e pela qual cada um, unindo-se a todos, só obedece contudo a si mesmo, permanecendo assim tão livre quanto antes. ,",36

O que é proposto por Rousseau é um pacto, que se “efetiva” a partir da “alienação total de cada associado, com todos os seus direitos, à comunidade toda, porque, em primeiro lugar, cada um dando-se completamente, a condição é igual para todos, e, sendo a condição igual para todos, ninguém se interessa por torná-la onerosa para os demais.” ${ }^{37}$ Ao associar-me, por necessidade e também por enxergar vantagens nisso $^{38}$, assumo não só esse compromisso de fazer a “alienação sem reservas” ${ }^{39}$, mas o de obedecer a vontade do corpo político - é assim que Rousseau denomina o produto ou resultado do pacto - , do qual agora faço parte, que é a vontade geral: “Cada um de nós põe em comum sua pessoa e todo o seu poder sob a direção suprema da vontade geral, e recebemos, enquanto corpo, cada membro como parte indivisível do todo.” ${ }^{40}$

Se o poder constituído é um poder legítimo, já que exigiu o meu consentimento $^{41}$, isso significa que devo me submeter a ele; devo obedecer por dever porque ao pactuar assumi esse compromisso - , e não posso esquecer que não obedecerei senão a mim mesmo. Aliás, não é essa a condição para que eu permaneça “tão livre quanto antes”? Caso eu me recuse a fazê-lo, serei constrangido por todo um corpo, o que não significa senão que me forçarão a ser livre ${ }^{42}$. A liberdade natural, que passou a não ter utilidade uma vez que não garantia mais a conservação do indivíduo, deu lugar à liberdade civil, que se limita pela vontade geral ${ }^{43}$.

Neste ponto vale a pena mencionar um dos argumentos que Rousseau apresenta na $1^{\text {a }}$ versão do Contrato Social contra a tese, contida no verbete Direito Natural,

\footnotetext{
${ }^{36}$ Ibidem, p.32.

${ }^{37}$ Ibidem, p.32.

${ }^{38}$ No capítulo VIII do livro I do Contrato Rousseau relaciona o que se ganha e o que se perde com o contrato social. O momento histórico apresenta uma situação que é desvantajosa para a maioria dos homens se comparada à situação "vivida” no estado de natureza. Não fosse isso, esse novo estado, o civil, seria superior ao estado de natureza, uma vez que é somente neste que podemos experimentar o "mais delicioso sentimento da alma: o amor pela virtude”.

${ }^{39}$ Rousseau, J-J. Do Contrato Social, p.32.

${ }^{40}$ Idem, p.33.

${ }^{41}$ Na verdade, o poder é legítimo não somente porque houve consentimento, mas principalmente porque atende aos critérios de liberdade e igualdade. O poder que é apresentado no segundo Discurso também é legítimo num primeiro momento, pois resulta de um pacto, portanto do consentimento dos indivíduos; porém, esse transforma-se em poder arbitrário quando passa a desprezar a igualdade, comprometendo, assim, a liberdade.

${ }^{42}$ Rousseau, J-J. Do Contrato Social, p. 36.

${ }^{43}$ Idem, p.36.
} 
publicado na Enciclopédia e atribuído a Diderot, que defende um "tratado social ditado pela natureza." 44 Um indivíduo que vivesse no estado de independência não veria vantagens em agir para com os outros segundo a lei social, uma vez que não estaria certo de que com ele agiriam da mesma forma ${ }^{45}$. No Contrato a condição que se impõe àquele que deseja pactuar é justamente a de agir segundo a vontade geral, e a força pública intervirá caso o compromisso não seja cumprido. A sanção, portanto, apresenta uma garantia e uma vantagem.

É próprio da vontade tender a um objeto, e esse é sempre um bem, pois ninguém deseja o seu próprio mal: “Jamais se corrompe o povo, mas freqüentemente o enganam e só então é que ele parece desejar o que é mau.”46 Mas o objeto ao qual a vontade geral, especificamente, deve tender é um objeto comum - um bem ou um interesse comum -, pois não há vontade geral visando objeto particular" ${ }^{47}$. "Assim, do mesmo modo que uma vontade particular não pode representar a vontade geral, esta, por sua vez, muda de natureza ao ter objeto particular e não pode, como geral, pronunciar-se nem sobre um homem, nem sobre um fato."48

Se na sociedade nascente ${ }^{49}$ é justamente a oposição dos interesses de cada indivíduo a causa da discórdia, não é a tais interesses que deve visar a vontade geral, mas àquele que corresponde ao ponto em que todos eles concordam ${ }^{50}$, ou seja, existe algo de comum nos vários interesses e é esse que deve ser considerado: “O que existe de comum nesses vários interesses forma o liame social e, se não houvesse um ponto em

\footnotetext{
${ }^{44}$ Rousseau, J-J. Du Contract Social (Ie version), p.284: « traitté social dicté par la nature ».

${ }^{45}$ Idem, p.284: “ 'C'est vainement', pourra-t-il ajoûter, 'que je voudrois concilier mon intérest avec celui d'autrui ; tout ce que vous me dites des avantages de la loi sociale pourroit être bon, si tandis que je l'observerois scrupuleusement envers les autres, j'étois sur qu'ils l'observeroient tous envers moi ; mais quelle sureté pouvez-vous me donner là-dessus, et ma situation peut-elle être pire que de me voir exposé à tous les maux que les plus forts voudront me faire, sans oser me dédomager sur les foibles ?...' » Rousseau atribui, acrescenta, estas palavras ao « raciocinador violento » suposto por Diderot.

${ }^{46}$ Rousseau, J-J. Do Contrato Social, p.46.

${ }^{47}$ Idem, p.54.

48 Ibidem, p.50.

49 Sociedade pré-política descrita como suposição no primeiro parágrafo deste bloco, “A sociedade ideal”. Corresponde àquela apresentada no Manuscrito de Genebra, p. 172: "Se em definitivo se estiver convencido de que entre esses motivos que levam os homens a se unirem entre si por laços voluntários, nada há que se assemelhe ao ponto de reunião; de que, longe de visar a um objeto comum, do qual cada um pudesse extrair a sua, a felicidade de um determina a desgraça do outro; se, finalmente, se compreender que, em lugar de tenderem todos para o bem geral, só se congregam porque tudo daquele bem os afasta - ter-se-á, também, de reconhecer que, se um tal estado pudesse subsistir, não passaria de uma fonte de crimes e misérias para homens que, cada um per si, só veriam o próprio interesse, só seguiriam suas inclinações e só ouviriam as próprias paixões.”

${ }^{50}$ Rousseau, J-J. Do Contrato Social, p.43.
} 
que todos os interesses concordassem, nenhuma sociedade poderia existir”. Logo, "somente com base nesse interesse comum é que a sociedade deve ser governada."

A soberania, que é o exercício da vontade geral, pertence ao povo, que não pode aliená-la nem dividi-la: “(...) a vontade ou é geral, ou não o é; ou é a do corpo do povo, ou somente de uma parte. No primeiro caso, essa vontade declarada é um ato de soberania e faz lei; no segundo, não passa de uma vontade particular ou de um ato de magistratura, quando muito, de um decreto.” ${ }^{52}$ Se as leis são atos da vontade geral ${ }^{53}$, e esta é a vontade do povo, então quer dizer que o autor de tais leis não deve ser senão o próprio povo, pois regulamentar as condições da sociedade cabe àqueles que se associam $^{54}$. Mas é neste momento que aparece o grande problema: “Como uma multidão cega, que freqüentemente não sabe o que deseja porque raramente sabe o que lhe convém, cumpriria por si mesma empresa tão grande e tão difícil quanto um sistema de legislação? O povo, por si, quer sempre o bem, mas por si nem sempre o encontra. A vontade geral é sempre certa, mas o julgamento que a orienta nem sempre é esclarecido. É preciso fazê-la ver os objetos tais como são, algumas vezes tais como eles devem parecer-lhe, mostrar-lhe o caminho certo que procura, defendê-la da sedução das vontades particulares, aproximar a seus olhos os lugares e os tempos, pôr em balanço a tentação das vantagens presentes e sensíveis com o perigo dos males distantes e ocultos.” 55

Para que a vontade possa escolher o bem, é necessário que este lhe seja mostrado ${ }^{56}$. Ela não pode querer algo que não conhece: “Deseja-se sempre o próprio bem, mas nem sempre se sabe onde ele está” ${ }^{\text {57 }}$. É tarefa do entendimento encontrar ou conhecer o bem verdadeiro e apresentar à vontade. Concorrem, portanto, para a produção da lei, entendimento e vontade ${ }^{58}$, e se tal lei não for conforme à natureza das

\footnotetext{
${ }^{51}$ Idem, p.43.

52 Ibidem, p.44.

53 Ibidem, p.55.

${ }^{54}$ Ibidem, p.55.

${ }^{55}$ Ibidem, p.56. Os grifos são nossos.

${ }^{56}$ Halbwachs, M. Du contrat social, p.174: « Il ne suffit pas que les hommes aient décidé de suivre la volonté générale, en fixant les limites, seulement, dans lesquelles celle-ci peut s’exercer. Encore faut-il qu'ils connaissent ce qu'elle décide. »

${ }^{57}$ Rousseau, J-J. Do Contrato Social, p.46.

${ }^{58}$ Idem, p.56 : « (...) das luzes públicas resulta a união do entendimento e da vontade no corpo social, daí o perfeito concurso das partes e, enfim, a maior força do todo.”
} 
coisas $^{59}$, não se deve atribuir o erro à segunda, mas ao primeiro - Rousseau insiste, ao longo do Contrato, que a vontade geral não erra. ${ }^{60}$

Embora o objetivo de Rousseau no famoso capítulo II do livro I do Manuscrito de Genebra seja mostrar a necessidade das instituições políticas, já que ele não acredita em uma “sociedade geral do gênero humano” regida apenas pela lei natural, alguns dos argumentos lá apresentados nos servem também aqui. Vejamos por quê.

Rousseau não discorda da definição de Diderot acerca da vontade geral: “(...) ninguém discordará quanto a ser a vontade geral, em cada indivíduo, um ato puro do entendimento que raciocina, no silêncio das paixões, sobre aquilo que o homem pode exigir de seus semelhantes e sobre o que este tem o direito de exigir dele” ${ }^{\text {}}$. O homem só desenvolve a faculdade intelectual em sociedade, porém, quando a ela pode recorrer - e falaremos ainda, mais adiante, da consciência -, as paixões ${ }^{62}$, que também nascem das relações sociais, já falam mais alto do que aquela. Além disso, conhecer a regra que deve guiar a ação humana não é tarefa simples: “(...) constituindo a arte de generalizar idéias um dos exercícios mais difíceis e tardios do entendimento humano, de tal sorte”, questiona Jean-Jacques, “estaria o comum dos homens em situação de extrair desse modo de raciocinar as regras de sua conduta?” E continua: “E, quando devesse consultar a vontade geral sobre um ato particular, quantas vezes não aconteceria a um homem bem intencionado enganar-se sobre a regra ou sua aplicação e, pensando obedecer às leis, seguir unicamente as próprias inclinações?”63

Já que o bem verdadeiro, neste caso o comum, só pode ser alcançado por meio de uma operação do entendimento, e tal operação é um exercício difícil e tardio, essa procura caberá a um Legislador: "Para descobrir as melhores regras de sociedade que convenham às nações, precisar-se-ia de uma inteligência superior, que visse todas as paixões dos homens e não participasse de nenhuma delas, que não tivesse nenhuma relação com a nossa natureza e a conhecesse a fundo; cuja felicidade fosse independente de nós e, contudo, quisesse dedicar-se a nós, que, finalmente, almejando uma glória

\footnotetext{
${ }^{59}$ Ibidem, p.53: “Aquilo que está bem e consoante à ordem, assim o é pela natureza das coisas e independentemente das convenções humanas.”

${ }^{60}$ Ibidem: Ver páginas 46, 49, 56 e 118.

${ }^{61}$ Rousseau, J-J. Manuscrito de Genebra, p.174-175.

${ }^{62} \mathrm{Na}$ verdade as paixões não nascem com a vida em sociedade, elas estão presentes no homem desde a sua existência. Porém, as paixões desenfreadas, destrutivas são fruto da vida social.

${ }^{63}$ Idem, p.175.
} 
distante, pudesse trabalhar num século e fruí-la em outro.” ${ }^{64}$ Somente alguém com estas características pode "raciocinar no silêncio das paixões”.

Embora ao Legislador só caiba a redação das leis, pois quem deve aprová-las é o povo, que não pode “despojar-se desse direito incomunicável (...)”65, sua função é de extrema relevância para a sociedade:“Aquele que ousa empreender a instituição de um povo deve sentir-se com capacidade para, por assim dizer, mudar a natureza humana, transformar cada indivíduo, que por si mesmo é um todo perfeito e solitário, em parte de um todo maior, do qual de certo modo esse indivíduo recebe sua vida e seu ser; alterar a constituição do homem para fortificá-la; substituir a existência independente, que todos nós recebemos da natureza, por uma existência parcial e moral. Em uma palavra, é preciso que destitua o homem de suas próprias forças para lhe dar outras que lhe sejam estranhas e das quais não possa fazer uso sem socorro alheio. Na medida em que tais forças naturais estiverem mortas e aniquiladas, mais as adquiridas serão grandes e duradouras, e mais sólida e perfeita a instituição, de modo que, se cada cidadão nada for, nada poderá senão graças a todos os outros, e se a força adquirida pelo todo for igual ou superior à soma das forças naturais de todos os indivíduos, poderemos então dizer que a legislação está no mais alto grau de perfeição que possa atingir.”66

O Legislador tem um papel semelhante ao do educador, pois deve contribuir para a formação do cidadão, em outras palavras, deve preparar o indivíduo para viver em comunidade ${ }^{67}$. Ao apresentar uma proposta de lei, ele aponta aquilo que será bom para todos - É dessa forma que o Legislador pode ensinar a alguns a conhecer o que querem $^{68}$, já que "o público quer o bem que não discerne” ${ }^{69}$ - , que beneficiará a todos. Não é porque a lei é civil que ela é necessariamente produto da escolha, da decisão do Legislador $^{70}$. Ele não inventa as leis; para alcançar o seu conteúdo ele recorre à sua

\footnotetext{
${ }^{64}$ Rousseau, J-J. Do Contrato Social, p.56.

${ }^{65}$ Idem, p.58.

${ }^{66}$ Ibidem, p.57.

${ }^{67}$ Ibidem, p.69. Sobre esse ponto, vale a pena reproduzirmos uma passagem das Considerações sobre o Governo da Polônia: "Cabe à educação dar aos espíritos uma formação nacional, orientando seus gostos e opiniões de modo que sejam patriotas por inclinação, por paixão e por necessidade.” (p.237)

${ }^{68}$ Durkheim, É. Montesquieu et Rousseau, p. 176: « (...) le peuple ne se suffit pas à lui-même pour faire la loi. S'il veut toujours le bien, il ne le voit pas toujours. Il faut quelqu'un pour éclairer son jugement. C'est le rôle du législateur. »

${ }^{69}$ Rousseau, J-J. Do Contrato Social, p.56.

${ }^{70}$ Reproduzimos aqui, como forma de reforçar o que foi dito, uma importante passagem de Durkheim, É em Montesquieu et Rousseau, p.196: «Si la loi civile ne peut être constituée que par un législateur, le législateur ne peut pas la faire à son gré ; pour qu'elle soit ce qu'elle doit être, il faut qu'elle soit conforme à la nature des choses. En tant que possible, elle ne dépend pas de l'arbitraire ; les conditions où se trouve la societé la déterminent nécessairement. »
} 
faculdade intelectual $^{71}$. Caso ele se engane, não sendo fiel àquilo que a natureza das coisas determina ${ }^{72}$, isso ocorreu em razão de um erro em seu entendimento, já que o juízo que orienta a vontade “nem sempre é esclarecido”. Mas a lei pode também não ser conforme a natureza das coisas se houver má intenção daquele que a propõe ao a aprova, tendo como fim um interesse particular ${ }^{73}$. Não é a toa que Rousseau sugere que o Legislador deve ser alguém que, além de ter uma inteligência superior, "visse todas as paixões dos homens e não participasse de nenhuma delas.”

Essa tarefa que cabe ao Legislador, de “mudar a natureza humana”, está relacionada com o domínio das paixões presentes nos homens. Se no estado de natureza o instrumento de adaptação ao meio físico era o instinto, no estado civil é a razão o instrumento de adaptação ao meio social ${ }^{74}$. Dela o homem deve fazer uso, deve consultá-la antes de ouvir suas inclinações ${ }^{75}$. Ora, aqui volta a dificuldade: como a maioria pode encontrar por si mesma as regras de conduta, recorrendo cada um a seu entendimento? Por isso que o Legislador, que é quem está apto a “descobrir as melhores regras de sociedade que convenham às nações”, redige as leis e sugere-as ao povo. Uma vez aprovadas, elas devem guiar as ações de todos. Seguir essas leis é colocar a razão acima das paixões, já que o conteúdo daquelas foi alcançado no “silêncio das paixões” e portanto está isento de arbitrariedade. Veremos mais adiante que só a razão não dá conta de frear as paixões, que são intensas no estado social; a consciência ocupa um papel importante e decisivo na determinação do agir humano ${ }^{76}$.

\footnotetext{
${ }^{71}$ Vale chamar a atenção para o fato de que "além das máximas comuns a todos, cada povo reúne em si alguma coisa que o dirige de modo todo especial e torna sua legislação adequada somente a si mesmo.” Rousseau, J-J. Do Contrato Social, p.68. O Legislador, portanto, deve ser capaz não somente de alcançar as regras que valem para todos como também as que são adequadas para um povo determinado, levando em conta as suas particularidades.

${ }^{72}$ Ibidem, p.68: "Mas, se o Legislador, enganando-se em seu objetivo, toma um princípio diverso daquele que nasce da natureza das coisas (...).”

${ }^{73}$ Nesse caso, aliás, nem se pode dizer lei. "Enfim, quando o Estado, próximo da ruína, só subsiste por uma forma ilusória e vã, quando se rompeu em todos os corações o liame social, quando o interesse mais vil se pavoneia atrevidamente com o nome sagrado do bem público, então a vontade geral emudece todos, guiados por motivos secretos, já não opinam como cidadãos, tal como se o Estado jamais tivesse existido, e fazem-se passar fraudulentamente, sob o nome de leis, decretos iníquos cujo único objetivo é o interesse particular.” Ibidem, p.118.

${ }^{74}$ Rousseau, J.-J. Discurso sobre a desigualdade, p.251: “O homem encontrava unicamente no instinto todo o necessário para viver no estado de natureza; numa razão cultivada só encontra aquilo de que necessita para viver em sociedade.”

${ }^{75}$ Rousseau, J-J. Do Contrato Social, p.36.

${ }^{76}$ Derathé, R. Le rationalisme de J.-J. Rousseau, p.97: «Il est vain de faire appel à la raison pour concilier notre intéret avec celui d'autrui, comme il est faux de croire qu'elle puisse servir de frein à nos passion. Pour ne pas rester lettre morte, les préceptes de la justice doivent s'appuyer sur un sentiment naturel au coeur humain ». Rousseau, J.-J. Discurso sobre a desigualdade, p.254-255: “Ainda que possa ser próprio de Sócrates e dos espíritos de sua têmpera adquirirem a virtude pela razão, há muito tempo o gênero humano não existiria mais, se sua conservação só dependesse dos que pertencem a esse grupo.”
} 
Não podemos esquecer que há aqueles que encontram por si o bem verdadeiro, porém, isso não é garantia de que vão agir segundo esse bem; por não resistirem $^{77}$, podem se dirigir àquilo que lhes causa prazer mais imediato, daí o fato de Rousseau afirmar: "Os particulares discernem o bem que rejeitam" ${ }^{78}$, por isso sua vontade deve ser conformada à sua razão ${ }^{79}$. Também com respeito a esses “particulares” o Legislador desempenha um papel importante, já que "todos necessitam, igualmente, de guias” ${ }^{80}$. Não contribui, no entanto, obrigando-os a conformar a vontade à razão daqueles, pois tal tarefa não lhe é atribuída - o Legislador não pode empregar a força ${ }^{81}$ - , mas na medida em que propõe leis que expressam o bem comum ${ }^{82}$. Uma vez essas instituídas todos têm o dever de cumpri-las.

Maurice Halbwachs, ao comentar o trecho "Os particulares discernem o bem que rejeitam”, diz, acertadamente, que se trata de os particulares preferirem seu interesse particular ao bem público. ${ }^{83}$ Rousseau já havia chamado a atenção ao dizer que: "Cada indivíduo, com efeito, pode, como homem, ter uma vontade particular, contrária ou diversa da vontade geral que tem como cidadão. Seu interesse particular pode ser muito diferente do interesse comum. Sua existência, absoluta e naturalmente independente, pode levá-lo a considerar o que deve à causa comum como uma contribuição gratuita, cuja perda prejudicará menos aos outros, do que será oneroso o cumprimento a si próprio. Considerando a pessoa moral que constitui o Estado como um ente de razão, porquanto não é um homem, ele desfrutará dos direitos do cidadão sem querer desempenhar os deveres de súdito - injustiça cujo progresso determina a ruína do corpo político" 84

O fato de se ter encontrado um ponto nos interesses particulares que coincidisse com o interesse comum possibilitou a formação do Estado; qualquer outro que não se

\footnotetext{
${ }^{77}$ Rousseau, J.-J. Discurso sobre a desigualdade, p.243: “A natureza manda em todos os animais, e a besta obedece. O homem sofre a mesma influência, mas considera-se livre para concordar ou resistir, e é sobretudo na consciência dessa liberdade que se mostra a espiritualidade de sua alma (...)."

${ }^{78}$ Rousseau, J-J. Do Contrato Social, p.56.

${ }^{79} \mathrm{~A}$ vontade deve ser conformada à razão, neste caso, para que o indivíduo tenda ao bem comum verdadeiro. A vontade sempre tende a um bem, seja ele particular verdadeiro, particular aparente, comum aparente ou comum verdadeiro.

${ }^{80}$ Rousseau, J-J. Do Contrato Social, p.56.

${ }^{81}$ Idem, p.59.

${ }^{82}$ Acreditamos que haja uma relação entre esta tarefa do Legislador e o conteúdo que Rousseau apresenta no último parágrafo do Manuscrito de Genebra, p.176: "Esclareçamos sua razão - aqui Rousseau referese justamente àquele que é capaz de enxergar o que é justo mas precisa ser convencido do "preço das boas ações" - com novas luzes, aqueçamos seu coração com novos sentimentos e esperemos que aprenda a multiplicar seu ser e sua ventura, dividindo-os com seus semelhantes.”

${ }^{83}$ Halbwachs, M. Du contrat social, p.173.

${ }^{84}$ Rousseau, J-J. Do Contrato Social, p.35-36.
} 
conforme com tal interesse comum deve ser desconsiderado. Se um indivíduo coloca seu interesse privado acima do interesse público e age tendo em vista o primeiro, portanto, pode acontecer que ele seja beneficiado, mas também pode ser que ele sofra, próxima ou futuramente, alguma conseqüência. O que é certo é que essa sua ação comprometerá o bem comum sempre, seja a curto, médio ou a longo prazo. Daí o motivo de Rousseau falar em "ruína do corpo político”.

Todos dependem do poder que se formou, mas para que esse perdure é necessário que cada um faça a sua parte, cumprindo seus deveres, caso contrário ele é colocado em risco. As “vantagens presentes e sensíveis” que são apresentadas à vontade particular fazem, muitas vezes, com que o indivíduo a prefira em detrimento da vontade geral. Acontece que essa escolha pode implicar dano para ele, daí o fato de Rousseau falar em “perigo dos males distantes e ocultos”. Mas evidente que Jean-Jacques está mesmo preocupado é com o prejuízo que possa sofrer o corpo político, e não o indivíduo ou um grupo particular.

É verdade que o homem é livre, mas não podemos esquecer que sua liberdade, no estado civil, é limitada pela vontade geral. Isso quer dizer que ele pode desejar ou escolher algo para $\mathrm{si}^{85}$ desde que esse algo beneficie a todos, ou que, pelo menos, não

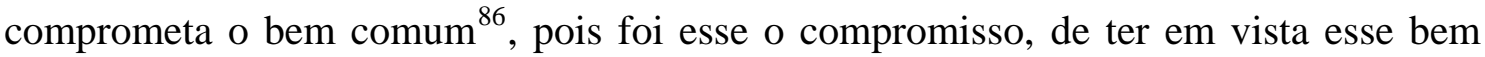
comum, que ele assumiu ao contratar. No artigo Economia Política Rousseau diz: "Para que a vontade geral seja cumprida, é preciso que todas as vontades particulares se ajustem a ela; em outras palavras, é preciso instituir o reinado da virtude, pois esta não é senão essa conformidade das vontades particulares com a vontade geral." ${ }^{87}$

Devemos chamar a atenção para o fato de que, quando Rousseau fala em vontade particular contrária à vontade geral, ele não está se referindo somente àquela de um indivíduo, mas leva em consideração a vontade particular de grupos isolados, o que parece ser mais preocupante: "Se, quando o povo suficientemente informado delibera, não tivessem os cidadãos qualquer comunicação entre si, do grande número de pequenas diferenças resultaria sempre a vontade geral e a deliberação seria sempre boa. Mas quando se estabelecem facções, associações parciais a expensas da grande, a vontade de cada uma dessas associações torna-se geral em relação a seus membros e

\footnotetext{
${ }^{85}$ Idem, p.48: « Relativamente a quanto, pelo pacto social, cada um aliena de seu poder, de seus bens e da própria liberdade, convém-se em que representa tão-só aquela parte de tudo isso cujo uso interessa à comunidade.”

${ }^{86}$ Há interesses particulares que são indiferentes ao interesse comum.

${ }^{87}$ Rousseau, J-J. Tratado sobre a Economia Política, p. 15.
} 
particular em relação ao Estado: poder-se-á então dizer não haver mais tantos votantes quantos são os homens, mas somente tantos quantas são as associações. As diferenças tornam-se menos numerosas e dão um resultado menos geral. E, finalmente, quando uma dessas associações for tão grande que se sobreponha a todas as outras, não se terá mais como resultado uma soma das pequenas diferenças, mas uma diferença única - então, não há mais vontade geral, e a opinião que dela se assenhoreia não passa de uma opinião particular." 88

Esse problema de a vontade ser geral em relação a algo mas particular em relação ao Estado também aparece quando Rousseau trata do governo, já que pode acontecer de a vontade dos governantes ser geral em relação àquele e particular em relação à vontade do corpo político. Falemos rapidamente do governo.

O mais importante a ser dito sobre o governo - ou príncipe, como Rousseau denomina-o - é que ele é um corpo, dentro de um corpo maior, que é o Estado, encarregado do poder executivo; é ele quem deve fazer valer a lei. Sua função, desempenhada pelos magistrados ou reis, que são os membros desse corpo, limita-se, porém, a isso. A feitoria das leis cabe ao soberano, como deixamos claro mais acima, e o governo deve obedecer às ordens daquele. “(...) a vontade dominante do príncipe só é, ou deveria ser, a vontade geral ou a Lei, e sua força não é senão a força pública nele concentrada: desde que deseje derivar de si mesmo qualquer ato absoluto e independente, começa a afrouxar-se a ligação do todo. Enfim, se porventura tivesse o príncipe uma vontade particular mais ativa do que a do soberano e, para obedecer a essa vontade particular, se utilizasse da força pública de que dispõe, de modo que se teriam, por assim dizer, dois soberanos, um de direito e outro de fato, imediatamente a união social desapareceria e dissolver-se-ia o corpo político.”89

No trecho reproduzido acima Rousseau menciona somente a vontade particular do príncipe, que é o governo considerado em seu todo. Tal vontade é particular em relação à vontade do Estado, mas é geral em relação à vontade governamental. Mais adiante ele fala da possibilidade de o magistrado ter uma vontade particular, aí esta não só é particular em relação ao próprio governo, como também o é em relação ao Estado. Ao mesmo tempo que o governo é indispensável, pois a comunidade política necessita de um órgão que a administre, ele também representa uma ameaça perpétua ${ }^{90}$.

\footnotetext{
${ }^{88}$ Rousseau, J-J. Do Contrato Social, p.47.

${ }^{89}$ Idem, p.78.

${ }^{90}$ Durkheim, É. Montesquieu et Rousseau, p.188.
} 
Até aqui tentamos expor um quadro com os principais elementos que constituem uma sociedade ideal, além de apresentar um ponto ${ }^{91}$ problemático que compromete tal quadro, que é o conflito entre indivíduo privado (homem natural) e indivíduo público (homem civil, ou cidadão). Uma sociedade renovada - em que a justiça e a felicidade estão em consonância ${ }^{92}$-,que se aproxima do estado que o homem desfrutava na origem, pressupõe esse problema solucionado. Isso significa que nessa sociedade o indivíduo não pode como homem "ter uma vontade particular contrária ou diversa da vontade geral que tem como cidadão”; ele não pode “desfrutar os direitos de cidadão sem querer desempenhar os deveres de súdito”. Falemos um pouco mais sobre esse ponto.

\subsection{Vontade geral versus vontade particular e amor da ordem versus amor do bem-estar material}

Há uma harmonia, uma ordem presente no estado de natureza. Rousseau distingue, ao menos no segundo Discurso, dois princípios inerentes à alma humana, anteriores à razão: “(...) meditando sobre as primeiras e mais simples operações da alma humana, creio nela perceber dois princípios anteriores à razão, um dos quais interessa profundamente ao nosso bem-estar e à nossa conservação, e outro nos inspira uma repugnância natural por ver perecer ou sofrer qualquer ser sensível e principalmente nossos semelhantes." 93 O primeiro princípio é denominado amor de si e o segundo piedade, os quais já havíamos mencionado no início deste capítulo. O que garante a ordem é justamente a presença, nos indivíduos, sobretudo do segundo princípio. Isso se traduz da seguinte maneira: o homem tem, nele, algo que o inclina a agir tendo em vista somente seu bem-estar e sua conservação, mas, ao mesmo tempo, tem nele algo que modera essa ação. Daí o importante papel da piedade que, "moderando em cada indivíduo o amor de si mesmo, concorre para a conservação mútua de toda espécie.”94

O amor de si e a piedade são duas regras seguidas pelo homem, que estão nele, mas que não são por ele conhecidas. A natureza dita ao homem que ele deve zelar pela

\footnotetext{
${ }^{91}$ Há outros pontos problemáticos, como o limite da extensão do Estado, por exemplo. Mas limitamo-nos a apontar aquilo que será importante para entendermos o papel da religião civil.

${ }^{92}$ Rousseau, J-J. Manuscrito de Genebra, p.176.

${ }^{93}$ Rousseau, J.-J. Discurso sobre a desigualdade, p.230.

${ }^{94}$ Idem, p.254.
} 
sua preservação e buscar o seu prazer; dita também o preceito: “Alcança teu bem com o menor mal possível para outrem.”95 Ele segue a primeira “ordem” observando o preceito, e o faz instintivamente. Daí dizer que a piedade, no estado de natureza, “ocupa o lugar das leis, dos costumes e da virtude, com a vantagem de ninguém sentir-se tentado a desobedecer à sua doce voz (...)."96 Por isso é que a ordem é aí mantida.

Quando da convivência, no entanto, começam a surgir novas paixões, aquela voz torna-se cada vez mais distante, sendo substituída pelo que Rousseau chama de amor próprio. Esse amor, portanto, só pode nascer em sociedade, e ele "não passa de um sentimento relativo, fictício (...), que leva cada indivíduo a fazer mais caso de si mesmo do que de qualquer outro, que inspira aos homens todos os males que mutuamente se causam e que constitui a verdadeira fonte da honra." 97 Se aquele sentimento natural (a piedade) que mantinha a ordem fica mais difícil, ou impossível, de ser consultado, a ordem vai dando espaço à desordem.

O lugar da piedade, no estado civil, é ocupado pela consciência. Como no estado de natureza não tínhamos a razão desenvolvida, não podíamos falar em bondade moral ${ }^{98}$, já que a moralidade pressupõe luzes; mas quando falamos de consciência estamos levando em conta essa aquisição. ${ }^{99}$

Embora Rousseau tenha estabelecido no Discurso sobre a desigualdade, como vimos, uma oposição entre amor de si e piedade, a consciência, que é uma extensão da piedade, é considerada, em outros escritos do autor, como sendo derivada do amor de si $^{100}$. Para assim considerá-la, ele admite a dualidade da natureza humana: "Meditando sobre a natureza do homem, acreditei descobrir nela dois princípios distintos, dos quais um o elevava ao estudo das verdades eternas, ao amor da justiça e do belo moral, às regiões do mundo intelectual cuja contemplação faz as delícias do sábio, e outro o trazia de volta baixamente a si mesmo, sujeitava-o ao império dos sentidos, às paixões que são seus ministros e contrariava por elas tudo o que lhe inspirava o sentimento do

\footnotetext{
${ }^{95}$ Ibidem, p.254.

${ }^{96}$ Ibidem, p.254.

${ }^{97}$ Ibidem, nota o, p.306. Os grifos são nossos.

98 Trecho do Emílio citado por Derathé em Le rationalisme de Jean-Jacques Rousseau, p.108, nota 1:

“ 'Avant l'âge de raison, nous faisons le bien et le mal sans le connaître; et il n’y a point de moralité dans nos actions, quoiqu'il y en ait quelquefois dans le sentiment des actions d'autrui qui ont rapport à nous.' » ${ }^{99}$ Idem, p.110: “'Le principe immédiat de la conscience, indépendant de la raison même' est une impulsion inée comme 'l’impulsion intérieure de la commisération'. Mais il y a bien de la différence entre cette impulsion primitive et la conscience complète, développée et devenue active par l'usage de la raison. »

100 Não só a consciência será assim considerada, mas também a própria piedade, a bondade e a generosidade. Derathé, em Le rationalisme de Jean-Jacques Rousseau, reproduz, na nota 4, que começa na página 99 e termina na 100, alguns trechos de escritos de Rousseau que ilustram isso.
} 
primeiro.”101 O homem, portanto, não é um ser simples, isto é, duas substâncias compõem sua essência, a saber, matéria e espírito. A primeira está ligada à natureza física do homem, e o segundo ao seu ser moral: “Enquanto as paixões, que são a voz do corpo, levam o homem em direção às fruições materiais e aos prazeres dos sentidos, um outro impulso, não menos natural, o eleva 'ao estudo das verdades eternas, ao amor da justiça e do belo moral.’ "102 De um lado, temos o que Rousseau denomina bem-estar material e, de outro, bem verdadeiro ou bem de nossa alma ${ }^{103}$.

Essa dualidade da natureza humana em espírito e matéria causa, portanto, a divisão do amor de si em "dois impulsos contrários, dos quais um não tem em vista senão nosso bem-estar material enquanto o outro é relativo ao bem de nossa alma e consiste no amor da ordem ou do belo moral." ${ }^{104}$ L'amour de l'ordre ou l'amour du beau, no original, são os dois termos que Rousseau emprega para designar a consciência, ou voz interior, que é um sentimento natural ao coração humano. ${ }^{105}$

A consciência só se desenvolve mediante o uso da razão, e para que eu ame o bem é necessário que eu antes o conheça: "Rousseau jamais afirmou que o conhecimento do bem é inato em nós; o que é inato é somente o impulso que nos coloca diante do bem e nos faz amá-lo. 'Conhecer o bem, diz ele na Profissão de fé, não é amálo; o homem não tem um conhecimento inato do bem, mas, assim que sua razão faz com que conheça, sua consciência leva-o a amá-lo; é este sentimento que é inato.' „106

A consciência, que é, portanto, um dos aspectos sob os quais o amor de si mesmo é encarado e se manifesta em nós ${ }^{107}$, deve ser vista como a mais elevada e a mais pura, comparada ao bem-estar material: "Ela é em nós o amor de nosso ser verdadeiro, já que o espírito é mais essencial à nossa natureza do que o corpo ao qual nos encontramos unidos por acidente. Graças a ela o bem de nossa alma não nos é

\footnotetext{
${ }^{101}$ Rousseau, J.-J., Emílio, p.392.

102 Derathé, R. Le rationalisme de Jean-Jacques Rousseau, p.101: «Tandis que les passions qui sont la voix du corps I'entrainent vers les jouissances matérielles et les plaisirs des sens, une autre impulsion non moins naturelle que la premiêre l'élève 'à l'étude des vérités éternelles, à l'amour de la justice et du beau moral' ".

103 Idem, p.100-101: « (...) notre bien véritable ne se confond nullement avec notre bien-être matériel. »

${ }^{104}$ Ibidem, p.101: “(...) deux impulsions contraires dont l'une n'a en vue que notre bien-être matériel tandis que l'autre est relative au bien de notre âme et consiste dans l'amour de l'ordre ou du beau moral ».

${ }^{105}$ Ibidem, p. 98: "Quelle est la nature de ce sentiment qui vient combattre en nous nos passions et nous porte a bien faire? Il consiste dans l'amour de l'ordre ou dans l'amour du beau, puisque Rousseau emploie indifferémment l'une ou l'autre de ces deux expressions pour désigner la conscience. »

106 Ibidem, p.110: “Rousseau n’a jamais affirmé que la connaissance du bien fût innée en nous ; ce qui est inné, c'est seulement l'impulsion qui nous porte vers le bien et nous le fait aimer. 'Connaître le bien, dit-il dans la Profession de foi, ce n'est pas l'aimer; l'homme n’en a pas la connaissance innée ; mais sitôt que sa raison le lui fait connaître, sa conscience le porte à l'aimer; c'est ce sentiment qui est inné.' »

107 Ibidem, p.99.
} 
indiferente e neste sentido ela representa com relação ao nosso ser espiritual o papel que representa o instinto de conservação com relação ao nosso ser físico.”108

Os interesses, que são aquilo que nos leva a agir ${ }^{109}$, têm uma relação com aquela divisão do amor de si, já que há um interesse que está ligado ao bem-estar material e outro ao bem-estar absoluto: “(...) há no homem duas espécies de interesse. O primeiro corresponde ao nosso ser físico: é um 'interesse sensual e palpável que se refere unicamente a nosso bem-estar material, à fortuna, à consideração, aos bens físicos que podem resultar para nós da boa opinião de outrem'. O segundo ao contrário ‘não é relativo senão a nós mesmos, ao bem de nossa alma, ao nosso bem-estar absoluto’. Rousseau o denomina ‘interesse espiritual ou moral.,”110

É conforme à natureza do homem que ele prefira seu interesse ao de outrem: “ ‘ Preferir-se ao todo é uma inclinação natural do homem’, diz Rousseau na Profissão de fé do vigário saboiano » ${ }^{111}$, porém, "praticar a justiça é preferir o bem de nossa alma a nosso bem-estar físico e pôr um interesse de ordem superior, nosso interesse verdadeiro enquanto ser pensante, antes de nossos interesses materiais.”112

A consciência exerce um papel decisivo na moral rousseauísta ${ }^{113}$, pois sem ela não há movimento da vontade: "Para que façamos o bem é preciso que estejamos interessados em fazer bem por um sentimento natural, já que o sentimento é o único motor da vontade.” ${ }^{114}$ Isso não quer dizer - o que precisa ficar claro - que a razão desempenhe um papel secundário nesse processo, pois, se sob um certo ponto de vista a

\footnotetext{
${ }^{108}$ Ibidem, p.102: "Elle est en nous l'amour de notre être véritable, puisque l'esprit est plus essentiel à notre nature que le corps auquel nous nous trouvons unis par accident. Grâce à elle le bien de notre âme ne nous est pas indifférent et en ce sens elle joue par rapport à notre être spirituel le rôle que joue l'instinct de conservation par rapport à notre être physique. »

${ }^{109}$ Ibidem, p.102: “(...) l'unique mobile de notre conduite est l'intérêt. »

${ }^{110}$ Ibidem, p.102: “(...) chez l'homme il y a deux sortes d'intérêt. Le premier correspond à notre être physique : c'est un 'intérêt sensuel et palpable qui se rapporte uniquement à notre bien-être matériel, à la fortune, à la consideration, aux biens physiques qui peuvent résulter pour nous de la bonne opinion d'autrui'. Le second au contraire 'n'est relatif qu'à nous-mêmes, au bien de notre âme, à notre bien-être absolu'. Rousseau l'appelle 'intérêt spirituel ou moral.' »

${ }^{111}$ Ibidem, p.99: «'Se préférer à tout est un penchant naturel à l'homme', dit Rousseau dans la Profession de foi du vicaire savoyard .»

${ }^{112}$ Ibidem, p.103: « Pratiquer la justice, c'est préférer le bien de notre âme à notre bien-être physique et faire passer un intérêt d'ordre supérieur, notre intérêt véritable en tant qu'être pensant, avant nos intérêt matériels. »

${ }^{113}$ Ibidem, p.106: “Ce qui fait l'originalité de Rousseau, c’est donc bien d'avoir réhabilité le sentiment et montré qu'il était indispensable à la vie morale, alors que la plupart des philosophes la faisaient dépendre uniquement des 'lumières de la raison.' » Rousseau, J.-J., Emílio, p.405: "Vezes demais a razão nos engana, conquistamos até demais o direito de recusá-la, mas a consciência nunca engana. Ela é o verdadeiro guia do homem; ela está para alma assim como o instinto está para o corpo.”

${ }^{114}$ Derathé, R. Le rationalisme de Jean-Jacques Rousseau, p.106: "Pour que nous fassions le bien il faut que nous soyons intéressés à bien faire par un sentiment naturel, puisque le sentiment est le seule moteur de la volonté. »
} 
consciência é independente daquela, sob outro não o é ${ }^{115}$, já que necessita dela para sua atividade: “ (...) a consciência só se desenvolve e age em conjunto com as luzes do homem. É só graças a essas luzes que ele atinge um conhecimento da ordem, e é só quando a conhece que sua consciência o leva a amá-la. A consciência, portanto, não existe no homem que ainda nada comparou e que não percebe suas relações.”"116

A razão é da ordem do conhecimento e a consciência é da ordem do sentimento. Mas antes de Rousseau se preocupar em saber como nós conhecemos o bem, ele se pergunta como nós podemos cumpri-lo. ${ }^{117}$ Nesse sentido a consciência ocupa um lugar de destaque: “Em Rousseau, é a consciência que passa ao primeiro plano, já que não se pode sem ela estabelecer a própria lei natural. Mudando de natureza, passando da ordem do conhecimento para a ordem do sentimento, ela muda também de valor e torna-se a noção fundamental da vida moral." 118

Há uma relação de dependência entre consciência e razão: “Elas são inseparáveis, pois a consciência não pode se desenvolver no homem sem as luzes da razão, em compensação aquela só pode se manter sã com a presença em nós da consciência.”"119 Assim, não é só a consciência que necessita da razão para se atualizar, mas também essa última deve ser submetida à direção daquela para que sua retidão seja garantida: “(...) a razão cessa de ser reta assim que ela deixa de se apoiar na consciência e quer privar-se do assentimento interior, única garantia da verdade de nosso pensamento e da retidão de nosso julgamento. 'Consciência! Consciência! Instinto divino; imortal e celeste voz, guia seguro de um ser ignorante e limitado, mas inteligente e livre; juiz infalível do bem e do mal...; sem você nada sinto em mim a não ser o triste privilégio de perder-me de

\footnotetext{
${ }^{115}$ Idem, p.111: « Comme toute impulsion naturelle, la conscience est indépendante de la raison dans son principe, parce que sa présence en nous ne résulte pas des connaissances que nous pouvons acquérir par le moyen de la raison, mais sans ces connaissances, elle 'resterait éternellement inactive' comme le serait également la pitié sans l'imagination qui vient la mettre en jeu. »

${ }^{116}$ Rousseau, J.-J, Carta a Christophe de Beaumont, p.48. Passagem do Emílio, citada por Derathé em Le rationalisme de Jean-Jacques Rousseau, p.111, que reforça essa idéia: “ “ La raison seule nous apprend à connaître le bien et le mal. La conscience qui nous fait aimer l'un et haïr l'autre, quoique indépendante de la raison, ne peut donc se développer sans elle.' »

${ }^{117}$ Derathé, R. Le rationalisme de Jean-Jacques Rousseau, p.106.

${ }^{118}$ Idem, p.106: “Chez Rousseau, c'est la conscience qui passe au premier plan, puisqu'on ne peut se passer d'elle pour établir la loi naturelle elle-même. En changeant de nature, en passant de l'ordre de la connaissance à celui du sentiment, elle change aussi de valeur et devient la notion fondamentale de la vie morale. »

${ }^{119}$ Ibidem, p.135: "Elles sont inséparables, car si la conscience ne peut se développer chez l’homme sans les lumières de la raison, en revanche celle-ci ne peut se maintenir saine que par la présence en nous de la conscience. »
} 
erros em erros, com o auxílio de um entendimento sem regra e de uma razão sem princípio.’ "120

No contexto da Profissão de fé, a prática da virtude, que está ligada àquela inclinação para a ação que tem em vista o bem verdadeiro, o bem de nossa alma, e que não se confunde com o bem-estar material, garante não só o que Rousseau vai chamar de contentamento consigo mesmo, além de uma indenização, mas também a volta à ordem que foi desfeita - embora tudo isso só seja alcançado numa vida futura ${ }^{121}$. Já a maldade que é praticada nas ações terá como conseqüência, naquele que a pratica, o tormento, que será a lembrança, depois da morte, de tudo o que foi durante a vida; mas Rousseau também acredita que a suprema justiça vinga-se já nesta vida ${ }^{122}$.

Da mesma forma que a piedade modera o amor de si para garantir a ordem no estado de natureza, a consciência também deve moderar o amor do bem-estar material. A voz da alma deve se elevar contra a lei do corpo. É verdade que o primeiro de todos os cuidados é o de nós mesmos; no entanto, aquela voz deve nos impor um limite para que não façamos o que é bom para nós à custa dos outros, pois isso seria fazer o mal. ${ }^{123}$

“'O próprio preceito de agir para com os outros como desejamos que ajam conosco, só tem um verdadeiro fundamento na consciência e no sentimento’, diz Rousseau no quarto livro do Emílio.”" ${ }^{24}$. Aquele que segue tal preceito é bom, e este “se ordena relativamente ao todo; (...) o mau ordena o todo relativamente a ele. Este faz-se o centro de todas as coisas; o outro mede seu raio e mantém-se na circunferência. Então ele é ordenado relativamente ao centro comum, que é Deus, e relativamente a todos os círculos concêntricos, que são as criaturas. Se a divindade não existe, apenas o mau raciocina e o bom não passa de um louco.” ${ }^{125}$

A identidade da dualidade espírito e matéria e amor da ordem e amor do bemestar material é fundamental para entendermos o funcionamento de um sistema que aponta Deus como “ ‘o sábio autor’ da ordem do universo, aquele ‘que formou o

\footnotetext{
${ }^{120}$ Ibidem, p.126: “(...) la raison cesse d'être droite dès qu'elle ne s'appuie plus sur la conscience et veut se passer de l'assentiment intérieur, seul garant de la vérité de notre pensée et de la droiture de notre jugement. 'Conscience! Conscience! Instinct divin ; immortelle et céleste voix, guide assuré d'un être ignorant et borné, mais intelligent et libre; juge infaillible du bien et du mal...; sans toi je ne sens rien en moi que le triste privilège de m'égarer d'erreurs en erreurs, à l'aide d'un entendement sans règle et d'une raison sans principe.' »

${ }^{121}$ Idem, p.400-401.

${ }^{122}$ Ibidem, p.400-401.

${ }^{123}$ Rousseau, J.J. Profissão de fé do vigário saboiano, p.405.

${ }^{124}$ Derathé, R. Le rationalisme de Jean-Jacques Rousseau, p.98, nota 1.

${ }^{125}$ Rousseau, J.-J. Emílio, p.414.
} 
universo e tudo o que existe, que tudo fez, tudo ordenou' "126 e o homem que, dotado de liberdade, pode alterar - e altera - essa ordem e, assim, criar a desordem no universo.

No contexto do Contrato Social temos presente a dualidade privado e público. Há no homem algo que o inclina unicamente para o seu bem e algo que modera tal inclinação fazendo com que concilie seu bem ao bem comum; trata-se da vontade particular e da vontade geral. Esta segunda é expressa pela lei civil, que justamente impõe um limite às ações dos homens - como a consciência o faz -, garantindo dessa forma a ordem social.

Podemos estabelecer aqui uma correspondência entre o bem comum, que é objeto da vontade geral, e o amor à ordem, que é concernente à parte espiritual do homem; mas não podemos associar o bem particular somente ao bem-estar material, pois, embora na maioria das vezes os homens sejam seduzidos pelas paixões, que, como vimos, são a voz do corpo, eles podem ter um interesse particular que não esteja necessariamente ligado à matéria.

O que é interessante notar é que o sistema apresentado na Profissão de fé, que coloca Deus no centro e o homem ordenado a esse centro na medida em que segue a voz interior, é reproduzido em termos políticos no Contrato. Aí temos o Estado no centro e o homem, que segue a vontade geral, ordenado a ele. A alienação total de cada um à comunidade toda é exatamente isso. Atribui-se ao Estado - dirigido pela vontade geral -, portanto, a tarefa de livrar o homem da escravidão e garantir, nesta vida mesmo, a justiça.

Se o amor da ordem, na Profissão de fé, deve superar no homem o amor do bemestar material, no Contrato o interesse particular deve estar subordinado ao interesse comum. Em outras palavras, tenho no primeiro sistema a ordem como objeto do amor, que determina a ação do homem e o faz superar suas paixões; no segundo tenho como objeto de interesse um bem comum, que inclina o homem a agir visando tal objeto, fazendo-o conciliar seu interesse com o interesse comum. O amor da ordem não é senão o amor de si, como o interesse comum não é senão o interesse de cada um: "Por que é sempre certa a vontade geral e por que desejam todos constantemente a felicidade de cada um, senão por não haver ninguém que não se aproprie da expressão cada um e não pense em si mesmo ao votar por todos?”127

\footnotetext{
${ }^{126}$ Cotta, Sergio, «Théorie Religieuse et Théorie Politique chez Rousseau », p.177.

${ }^{127}$ Rousseau, J-J. Do Contrato Social, p.47.
} 
Não esqueçamos que o objeto da vontade geral é o bem comum e que o conhecimento deste só é alcançado por meio de uma operação do entendimento. No entanto, como vimos, discernir o bem não é garantia da ação reta. Os particulares podem rejeitar o bem - expresso em uma lei - que discernem se são tomados por paixões muito fortes, ainda que a lei tenha sanção.

A razão, no Contrato Social, é a base da sociedade: “A passagem do estado de natureza para o estado civil determina no homem uma mudança muito notável, substituindo na sua conduta o instinto pela justiça e dando às suas ações a moralidade que antes lhes faltava. É só então que, tomando a voz do dever o lugar do impulso físico, e o direito o lugar do apetite, o homem, até aí levando em consideração apenas sua pessoa, vê-se forçado a agir baseando-se em outros princípios e a consultar a razão antes de ouvir suas inclinações.” ${ }^{128}$ No entanto, tendo em vista todos os obstáculos que apontamos, Rousseau recorre - também aqui - a uma base mais sólida do que a pura razão. $^{129}$

Embora de maneira bem rápida, tentamos mostrar a relevância da consciência no sistema moral de Rousseau. E apesar de o filósofo não mencioná-la no Contrato Social, ela às vezes parece ocupar um lugar de maior destaque ${ }^{130}$. A consciência, como a razão, dita ao homem as regras de conduta, com a diferença de que a sua fonte é o coração. Contudo, mesmo ela, que aparenta exercer influência mais forte sobre o indivíduo, se cala diante de paixões arrebatadoras ${ }^{131}$.

Se a razão, pelos motivos que já apresentamos, e também a consciência, nem sempre funcionam como freios às paixões, Rousseau chama a religião em apoio à moral.

É somente a lei, no Estado, que garante a liberdade, e submeter-se a ela é submeter-se à razão - e, se levarmos em consideração o sistema apresentado na Profissão de fé e em outros escritos de Rousseau, também à consciência, escutando a sua voz - devo fazer com que ela se sobreponha às minhas paixões: “De uma maneira

\footnotetext{
${ }^{128}$ Ibidem, p.36.

${ }^{129}$ Rousseau, J.-J. Discurso sobre a desigualdade, p.276.

${ }^{130}$ Derathé, R. Le rationalisme de J.-J. Rousseau, p. 93: « D’une manière générale Rousseau nie que la raison puisse par elle-même servir de moteur à la volonté: 'La seule raison, dit-il dans l'Émile, n'est point active, elle retient quelque fois, rarement elle excite, et jamais elle n'a rien fait de grand'. Certes la raison peut éclairer notre conduite, mais l'impulsion vient toujours du sentiment .»

${ }^{131}$ Rousseau, J.-J. Emílio, p.412: “Mas não basta que esse guia exista, é preciso saber reconhecê-lo e segui-lo. Se ele fala a todos os corações, por que há tão poucos que o escutam? Ah, é que ele nos fala a língua da natureza, que tudo nos fez esquecer. A consciência é tímida, ela ama o sossego e a paz; o mundo e o barulho assuntam-na, os preconceitos de que a fazem nascer são seus mais cruéis inimigos; ela foge ou cala-se diante deles; sua voz sonora abafa a dela e a impede de se fazer ouvir. O fanatismo ousa contrafazê-la e ditar o crime em seu nome.”
} 
geral, não se pode alcançar a liberdade senão pela submissão às leis, naturais ou civis, pois ambas tendem à mesma finalidade: assegurar a liberdade do homem apesar de suas paixões.” ${ }^{132}$ É só a lei, além disso, que pode servir como instrumento de conservação do corpo político. Veremos que a religião civil terá um papel fundamental na medida em que reforça - e força - o cumprimento da lei.

O homem no estado de natureza era feliz ${ }^{133}$ porque tinha poucas paixões; elas, no estado social, o tornam escravo e por isso sua felicidade depende do domínio dessas paixões. A prática da virtude e, por conseqüência, a boa convivência entre os indivíduos em um Estado estão relacionadas com o controle que esses devem ter sobre suas paixões. Ele pode escolher entre sua própria escravidão ou sua liberdade. Quando contrata é pela segunda que opta, o que exige dele a condição de ter em vista, ao agir, o bem comum. A tarefa, porém, é a das mais difíceis.

A lei, se for respeitada, dá conta de manter a ordem. A repressão existe, aliás, para fazer valer a lei. Como os indivíduos adeririam ao pacto se não tivessem essa garantia? Aquele que é punido deverá aprender ${ }^{134}$ que não deve descumprir a lei, pois coloca em risco a sociedade e sua própria liberdade. Se Rousseau sugere a introdução de uma religião no Estado, é para que ela reforce a importância das leis e faça com que o cidadão não seja levado a romper o pacto, isto é, não descumpra a lei. Assim, menos se necessitará recorrer à força, ainda que esta seja legítima ${ }^{135}$.

Foi a vida em sociedade que tornou o homem mau, mas é somente ela, sob as condições que apontamos até aqui, que pode livrá-lo do mal, que pode garantir a sua salvação - na terra. Daí termos falado no "primado do político". Se a religião entra nessa estrutura montada é porque ela pode dar a sua grande contribuição. Por exercer influência sobre os indivíduos, pode persuadi-los a cumprir seus deveres, sendo mantida, dessa forma, a ordem social.

\footnotetext{
${ }^{132}$ Derathé, R. Le rationalisme de Jean-Jacques Rousseau, p.122: “D’une façon générale la liberté ne peut s'acquérir que par la soumission aux lois, lois naturelles ou lois civiles, car les unes et les autres tendent au même but: assurer la liberté à l'homme malgré ses passions. »

${ }^{133}$ Na verdade só faz sentido falar em felicidade em comparação com estado de guerra no qual se encontra o homem na sociedade nascente, pois sem a razão desenvolvida no estado de natureza, o homem não poderia saber o que isso significa. “(...) a vida feliz da idade de ouro sempre foi um estado estranho à raça humana, ou por não tê-la conhecido quando dela pudera gozar, ou por tê-la perdido quando poderia conhecê-la." Manuscrito de Genebra, p.172.

${ }^{134} \mathrm{~A}$ punição não serve só para fazer com que aquele que descumpriu uma regra pague por isso, mas serve como lição para que o erro, ou a má ação, não se repita.

${ }^{135}$ Legítima porque compõem a idéia de pacto a entrega ao corpo político, e este se baseará na lei, e a repressão àqueles que deixarem de cumprir com o que foi estabelecido.
} 


\section{Capítulo II}

\section{A religião civil}

\subsection{Introdução}

Foram desenvolvidos três tópicos neste capítulo, a saber, "A religião civil no Contrato Social”, “A religião natural” e “A religião em outros escritos de Rousseau”.

No primeiro tópico, mostramos em que momento no Contrato Social Rousseau aponta a religião, pela primeira vez, como necessária dentro da estrutura que montou. Depois, fizemos uma exposição - discutimos os pontos principais - do capítulo VIII do livro IV dessa mesma obra, intitulado “Da religião civil”, com o objetivo de mostrar que espécie de religião deve ter o Estado para que sua manutenção seja garantida. No capítulo I expusemos os argumentos que provam a necessidade de uma religião no modelo de sociedade que Rousseau propõe. Com este tópico quisemos falar de que tipo de religião se trata e, sobretudo, da função que ela tem.

Como a religião civil não é senão a religião natural desenvolvida na Profissão de fé, acrescida de um dogma civil - que não está contido na religião natural -, no segundo tópico, apresentamos os dogmas, ou artigos de fé estabelecidos pelo personagem Vigário saboiano. Não pretendíamos com isso repetir os dogmas que são enunciados no Contrato Social, mas a intenção era mostrar que a religião nos dois escritos, mesmo tendo contextos diferentes, tem a mesma função: persuadir o indivíduo - ou cidadão, no caso do Contrato - a cumprir seus deveres na terra. No Contrato Rousseau afirma que “é impossível ser bom cidadão ou súdito fiel”"136 se não houver a crença nos dogmas que formam a religião civil. Na Profissão de fé a afirmação é: “(...) sem a fé não existe nenhuma verdadeira virtude.” ${ }^{137}$ Na primeira obra o dever - que se traduz sobretudo no respeito à lei - tem de ser cumprido para que a conservação de todos seja garantida; na segunda obra, a boa ação garante a volta à ordem numa vida futura, e também a felicidade. Além disso - o que nos parece ser o ponto mais importante -, na Profissão de fé temos uma melhor idéia do porque de a religião ter o poder de persuadir, e isso reside no fato de haver um Deus bom que, numa outra vida, indenizará os que praticaram o bem e foram injustiçados e punirá os que abusaram da liberdade fazendo o

\footnotetext{
${ }^{136}$ Rousseau, J.-J. Do Contrato Social, p.144.

${ }^{137}$ Idem, Profissão de fé do vigário saboiano, p.446.
} 
mal. A esperança numa vida além da terrena, portanto, é fundamental para que um grande número de pessoas seja motivado a fazer a sua parte nesta vida. No Contrato os dogmas são somente enunciados, e não explicados, como na Profissão de fé.

No terceiro tópico, quisemos mostrar que a religião foi apontada em outros escritos de Rousseau, tanto nos anteriores como nos posteriores ao Contrato Social, como necessária na constituição de um corpo político. No caso da religião civil, falamos de sua formulação antes de ela aparecer mais bem desenvolvida no Contrato. Isso tem relevância porque mostra que a proposta da religião civil não é uma solução de última hora e não compromete o modelo de sociedade que tem como base a razão e a consciência.

\subsection{A religião civil no Contrato Social}

A afirmação da necessidade do recurso à religião já aparece no capítulo VII do livro II do Contrato Social, intitulado "Do Legislador"138. Rousseau admite, ao concluir tal capítulo, que na origem das nações a religião serve de instrumento à política e a política à religião, mas faz questão de esclarecer que elas não têm um objeto comum. ${ }^{139}$

A religião tem uma linguagem familiar ao povo ${ }^{140}$; além disso, até que todos, ou pelo menos a maioria, estejam convencidos das vantagens que podem tirar das contínuas privações que as boas leis lhes impõem ${ }^{141}$, é preciso que sejam persuadidos.

\footnotetext{
${ }^{138}$ É interessante chamarmos a atenção para o fato de que na $1^{\text {a }}$ versão do Contrato, o capítulo sobre a religião civil (também uma primeira versão), que não tinha título, estava contido no verso do capítulo sobre o Legislador que, aliás, como aponta Halbwachs, era o único em que Rousseau havia feito apelo à religião. Como esse capítulo - ou poderíamos utilizar "conteúdo", uma vez que não tinha título - só foi acrescentado depois (no rascunho), Maurice Halbwachs, por exemplo, supõe duas coisas: « (...) ou bien qu'il a rédigé le chapitre sur la religion civile aussitôt après avoir écrit ce chapitre sur le législateur, ne sachant d'ailleurs encore où il le placerait, ou bien que, le manuscrit étant entièrement terminé, il l'a ajouté et écrit au verso de ce chapitre comme s'il voulait d'abord le placer en cet endroit. » Du Contrat Social, p.431: Commentaire. De qualquer forma, se esse conteúdo foi escrito no verso do capítulo sobre o legislador, é porque constitui um complemento natural deste, o que parece certo para Derathé (Du Contrat Social, Notes et Variantes, p.1498).

${ }^{139}$ Rousseau, J.-J. Do Contrato Social, p.60.

${ }^{140}$ Sobre esse ponto vale comentar aqui que Hobbes, no capítulo XXVI do Leviatã, intitulado "Das Leis Civis", lembra os recursos utilizados pelos Legisladores antigos não só para tornar o povo judeu ciente das leis, mas para que ele as fixasse na memória. "E nos tempos antigos, quando as cartas ainda não eram de uso comum, muitas vezes as leis eram postas em versos, para que o povo inculto, tomando prazer em cantá-las e recitá-las, pudesse mais facilmente guardá-las na memória. Pela mesma razão, Salomão aconselhou a um homem que estabelecesse uma relação entre os dez mandamentos e seus dedos. E Moisés, quando deu a lei ao povo de Israel, na renovação do contrato, recomendou que a ensinassem a seus filhos discorrendo sobre ela tanto em casa como nos caminhos, tanto ao deitar como ao levantar, e escrevendo-a nos montantes e nas portas de suas casas; e também que reunisse o povo, homens, mulheres e crianças, para a ouvirem ler.” (p. 212)
} 
A regra de conduta humana, que se obtém da generalização das idéias exercício difícil e tardio do entendimento humano, vale lembrar -, é muito complicada de traduzir-se na língua do povo. O Legislador alcança o que servirá como princípio da ação dos indivíduos, ou seja, a lei, e fará uso da religião para transmiti-la à multidão. "Essa razão sublime, que escapa ao alcance dos homens vulgares, é aquela cujas decisões o Legislador põe na boca dos imortais, para guiar pela autoridade divina os que a prudência humana não poderia abalar.,"142

A lei deve transformar os homens, deve criar a "obra da instituição", isto é, o “espírito social”. Seria preciso, no entanto, que um povo nascente compreendesse as sãs máximas da política e seguisse as regras fundamentais da razão de Estado. ${ }^{143}$ Mas como isso não é possível num primeiro momento, justamente porque a sociedade política acabou de se formar, e aquela faculdade fundamental ao indivíduo - o entendimento ainda está em desenvolvimento, a religião torna-se um instrumento necessário de persuasão.Antes de convencer o povo de que algo é bom para ele, ele pode - e deve ser persuadido.

A obra da qual se ocupa o grande Legislador é aquela lei “que não se grava nem no mármore, nem no bronze, mas nos corações dos cidadãos; que faz a verdadeira constituição do Estado; que todos os dias ganha novas forças; que, quando as outras leis envelhecem ou se extinguem, as reanima ou as supre, conserva um povo no espírito de sua instituição e insensivelmente substitui a força da autoridade pela do hábito.”144 Rousseau a denominará “usos e costumes” e “opinião”. O filósofo afirma que esses são lentos para nascer, mas quando nascem "formam a chave indestrutível”145. Porque aí já não é mais da regra que se trata, mas da própria ação virtuosa, que pressupõe a regra reta.

Um longo trabalho deverá ser feito para que se consiga chegar até esse resultado, e é então que o Legislador, pelos motivos que já mencionamos, "não podendo empregar nem a força nem o raciocínio, recorre necessariamente a uma autoridade de outra ordem, que possa conduzir sem violência e persuadir sem convencer.”146

Falamos até agora da importância do recurso à religião, mas não falamos de que religião se trata. Rousseau propõe uma religião civil. Faremos uma análise do capítulo

\footnotetext{
${ }^{141}$ Rousseau, J.-J. Do Contrato Social, p.58.

${ }^{142}$ Idem, p.59

${ }^{143}$ Ibidem, p.58.

${ }^{144}$ Ibidem, p.69.

${ }^{145}$ Ibidem, p.69.

${ }^{146}$ Ibidem, p.59.
} 
VIII do livro IV do Contrato, que tem como título "Da religião civil”"147, para mostrar em que consiste essa religião. Também veremos por que Rousseau rejeita as religiões históricas, sobretudo o cristianismo, como apoio de uma sociedade. Aliás, nenhum capítulo suscitou tantas polêmicas e protestos no século XVIII quanto este, sobretudo, justamente, por conter a crítica a essa religião ${ }^{148}$.

O Estado necessita de uma religião que acrescente uma força às leis além daquelas que elas tiram de si mesmas ${ }^{149}$. Este já é, por sinal, um dos argumentos que Rousseau utilizará ao recusar o cristianismo como religião do corpo político. O cristianismo não só não acrescenta essa força, ficando "sem efeito um dos grandes elos da sociedade particular” ${ }^{150}$, como também é contrário ao espírito social: “(...) longe de ligar os corações dos cidadãos ao Estado, desprende-os, como de todas as coisas da terra. Não conheço nada mais contrário ao espírito social.”"151

A religião deve fazer o cidadão amar seus deveres, pois assim ele tem mais possibilidades de cumpri-los. “Ora, não cumpre seu dever senão o homem que o ama e é preciso chamar religiosa esta inclinação para amar o dever com todos os sacrifícios que ele pode exigir." 152 Por isso importa ao Estado que cada um tenha uma religião que atenda esse requisito ${ }^{153}$. O cidadão deve ser bom nesta vida. Portanto, desde que obedeça aos deveres expressos nos dogmas da religião que professa - e são apenas tais dogmas que interessam ao Estado e a seus membros - “cada um pode ter as opiniões que lhe aprouver, sem que o soberano possa tomar conhecimento delas, pois, como não

\footnotetext{
${ }^{147}$ Pierre Maurice Masson considera este capítulo como um «petit traité politique de la religion”. La religion de J.J. Rousseau (chapitre V du livre II : « Le problème de la religion civile », p. 178).

${ }^{148}$ Derathé, R. Du Contrat Social, Notes et Variantes, p.1499. Comentário parecido no artigo «La religion civile selon Rousseau, p.161: “Au moment de la publication du Contrat social, c'est la religion civile qui a suscité le plus de polémiques et d'indignation, surtout dans les milieux genevois, comme en témoigne la correspondance de Rousseau. »

${ }^{149}$ Rousseau, J.-J. Do Contrato Social, p.141. A autoridade das leis deve ser reforçada pela autoridade da religião.

${ }^{150}$ Idem, p.141.

${ }^{151}$ Ibidem, p.141-142.

${ }^{152}$ Gouhier, H. Les méditations métaphysiques de Jean-Jacques Rousseau, p.251: « Or, ne fait son devoir que l'homme qui aime son devoir et il faut bien appeler religieuse cette inclination à aimer le devoir avec tous les sacrifices que celui-ci peut exiger. »

${ }^{153}$ No Contrato Rousseau limita-se a apontar a religião como instrumento que reforça os laços de sociabilidade, mas há outros meios, e, nas Considerações, ele menciona quais são. Ao se referir aos Legisladores antigos ele diz: “(...) todos eles buscaram laços que unissem os cidadãos à pátria, assim como uns aos outros, encontrando esses vínculos em determinados costumes, em cerimônias religiosas (vide a parte final do Contrato Social), em jogos que mantinham os cidadãos reunidos por muito tempo; em exercícios que, aumentando a sua força física, fortaleciam também o seu amor próprio e sua auto confiança; em espetáculos que, lembrando-lhes a história dos seus antepassados, suas virtudes, tristezas e vitórias, interessavam o seu coração, inflamando-os e ligando-os fortemente a essa pátria com a qual eram mantidos sempre ocupados.” (p.228)
} 
chega sua competência ao outro mundo, nada tem a ver com o destino dos súditos na vida futura (...).”154

Rousseau é radical ao ponto de afirmar que é impossível ser bom cidadão ou súdito fiel sem os "sentimentos de sociabilidade", que devem ser fixados pelo soberano. Tais sentimentos - porque os considera mais como sentimentos do que como artigos ou dogmas de religião - dizem respeito a uma profissão de fé puramente civil. ${ }^{155}$

Prestemos atenção aos termos empregados por Rousseau: "ligar os corações dos cidadãos ao Estado”, “amar seus deveres”, “sentimentos de sociabilidade”. Lembremos que no capítulo I falamos da necessidade que Jean-Jacques sentiu de recorrer a uma “base mais sólida do que a pura razão” para que todos pudessem enxergar a importância do contrato social e, logo, das leis. Essa base era a religião, e esta, por sua vez, como vimos há pouco, é um instrumento de persuasão. A persuasão toca nas emoções e nas paixões dos indivíduos e não no raciocínio ou na inteligência deles. O uso desses termos parece confirmar isso.

A religião civil parece ser uma solução encontrada por Rousseau que tenta unir a religião do homem àquela do cidadão ${ }^{156}$. No Manuscrito de Genebra, depois de expor quase todo o conteúdo do capítulo sobre a religião civil que, por ser mais curto, por apresentar algumas diferenças e até mesmo por conter trechos que não tem no Contrato, é um pouco diferente do capítulo inserido na versão definitiva, Rousseau conclui que com a proposta da religião civil será possível reunir as vantagens da religião do homem às vantagens da religião do cidadão ${ }^{157}$. Vejamos, então, como ele concebe cada uma dessas religiões.

A religião do homem é associada ao cristianismo; à religião do cidadão, correspondem as religiões antigas, pagãs ${ }^{158}$. Além disso, Rousseau considera uma terceira espécie de religião, “mais estranha, que, dando ao homem duas legislações, dois chefes, duas pátrias, o submete a deveres contraditórios e o impede de poder ao mesmo tempo ser devoto e cidadão. Tal é”, revela o filósofo, “a religião dos lamas, a dos japoneses e a do cristianismo romano. Pode-se chamar, a esta, religião do padre.”159

\footnotetext{
${ }^{154}$ Rousseau, J.-J. Do Contrato Social, p.143. Sobre este ponto, veremos que Rousseau, na Carta a Christophe de Beaumont, adota uma outra posição.

155 Idem, p.143.

${ }^{156}$ Para Masson, Rousseau retirou esta distinção do Devoirs de l'homme et du citoyen, de Pufendorf. La religion de J.J. Rousseau (chapitre V du livre II : « Le problème de la religion civile », p. 200).

${ }^{157}$ Rousseau, J-J. Du Contrat Social (Ie version), p.342.

158 «Celle des peuples et cités de l'antiquité. » Halbwachs, M. Du Contrat Social, p.421, nota 370.

${ }^{159}$ Rousseau, J.-J. Do Contrato Social, p.141.
} 
Embora as três apresentem, do ponto de vista político, graves defeitos ${ }^{160}$, ele retira delas aquilo que têm de positivo, excetuando a terceira, que é “evidentemente má”161.

A religião do cidadão é boa se considerada num âmbito muito restrito, que é o da própria nação; fora dele, no entanto, ela é nociva. O Estado, no paganismo, não fazia distinção entre seus deuses e suas leis ${ }^{162}$. Essa religião unia o culto divino ao amor das leis, e, fazendo da pátria objeto de adoração dos cidadãos, lhes ensinava que servir o Estado era servir o deus tutelar ${ }^{163}$. Acontece que ela torna um povo intolerante na medida em que esse impõe seus deuses a outros povos utilizando-se da força caso aqueles os rejeitem. Esta é a segunda razão pela qual Rousseau aponta a religião pagã como má, sendo a primeira o fato de que ela ao fundar-se, segundo ele, no erro e na mentira, "engana os homens, torna-os crédulos, supersticiosos, submerge o verdadeiro culto da Divindade num cerimonial vão.”164

No início do capítulo, Rousseau afirma que o politeísmo - segundo Halbwachs, possivelmente entendido não como a crença em diversos deuses, mas como a idéia de tantos deuses diferentes quanto são os povos ou as cidades ${ }^{165}$ - é o resultado das divisões nacionais, e é de dele, por sua vez, que nasce a intolerância teológica e civil “que naturalmente é a mesma (...)”. 166

Quanto à religião do homem, antes de relacionarmos seus pontos positivos e negativos, vale esclarecer que Rousseau se refere à "religião pura e simples do Evangelho, o verdadeiro teísmo e aquilo que pode ser chamado de direito divino natural” ${ }^{\prime 67}$. O cristianismo considerado como religião instituída, à qual Rousseau emite uma crítica ferrenha dizendo que "tudo o que rompe a unidade social, nada vale; todas as instituições que põem o homem em contradição consigo mesmo, nada valem”168, corresponde ao que ele apresenta como sendo a “terceira espécie de religião”.

\footnotetext{
160 « (...) toutes, à bien prendre, sont nuisibles à État (...). Masson, P.M. La religion de J.-J Rousseau, t.II, p.179

${ }_{161}$ Rousseau, J.-J. Do Contrato Social, p.141.

${ }^{162}$ Idem, p.138.

163 Ibidem, p.141.

${ }^{164}$ Ibidem, p.141.

${ }^{165}$ Halbwachs, M. Du Contrat Social, p.432, Commentaire.

166 Rousseau, J.-J. Do Contrato Social, p.138. Ainda sobre este ponto, Halbwachs comenta: "L'intolérance théologique et civile est la même en de telles conditions, parce qu'on ne peut pas distinguer alors la cité et son culte.” Du Contrat Social, p.432, Commentaire.

${ }^{167}$ Ibidem, p.140.

${ }^{168}$ Ibidem, p.141.
} 
Ao contrário da religião pagã ${ }^{169}$, que é exclusiva de um Estado, ou seja, não ultrapassa os muros deste, sendo este um dos aspectos que a tornam má ${ }^{170}$, o cristianismo - “não o de hoje, mas o do Evangelho, que é completamente diverso" ${ }^{171}$ não conhece limites, nem no espaço nem no tempo. Desse ponto de vista, a religião do homem merece, mais do que as outras, ser considerada como uma religião (verdadeira religião). ${ }^{172}$ Como é a religião do homem em geral, e não a de grupos ou Estados particulares, todos, filhos do mesmo Deus, reconhecem-se como irmãos, e “a sociedade que os une não se dissolve nem com a morte.” ${ }^{173}$ Eis o que essa religião apresenta de positivo.

Embora a religião do Evangelho seja “santa, sublime, verdadeira” ${ }^{174}$, ela apresenta muitos pontos negativos, que superam aquilo que ela tem de bom. No capítulo que estamos examinando, Rousseau dedica mais de uma página à crítica ao que ele denomina religião do homem. A principal razão que sustenta a tese que diz que não há nada mais contrário ao espírito social do que essa religião é o fato de ela preocupar-se com uma outra vida, deixando de lado a vida terrena: "O cristianismo é uma religião inteiramente espiritual, preocupada unicamente com as coisas do céu, não pertencendo a pátria do cristão a este mundo.”175

O cristão vive em função da outra vida, ou do outro mundo; cumpre seu dever, mas toma cuidado para não tentar a Deus, que é quem decide sobre sua vida e sabe o que é melhor para ele. Dessa forma, todas as justificativas dos acontecimentos, sejam bons ou ruins, encontram-se na vontade de Deus. Mas o que importa é alcançar o paraíso, mesmo que seja necessária a resignação a qualquer situação, já que esta “não passa de mais um meio para isso.”176

\footnotetext{
${ }^{169}$ Limitamo-nos aqui a expor as idéias de Rousseau sobre a religião pagã, já que se trata de um assunto complexo e exigiria, caso quiséssemos aprofundar-nos, um estudo mais cuidadoso e uma bibliografia diversa.

170 "Afora a única nação que a segue, todos os demais para ela são infiéis estrangeiros e bárbaros; ela só leva os deveres e os direitos do homem até onde vão seus altares.” Rousseau, J.-J. Do Contrato Social, p.140-141.

${ }_{171}$ Rousseau, J.-J. Do Contrato Social, p.141.

${ }^{172}$ Halbwachs, M. Du Contrat Social, p.422, nota 374 : « Par 'religion véritable', Rousseau n'entend pas : religion vraie, dont les dogmes seraient autant de vérités, mais plutôt qu'elle mérite plus que les autres d'être considérée comme une religion (une véritable religion), parce qu'elle ne connait pas de limites, ni dans l'espace, ni dans le temps. »

${ }^{173}$ Rousseau, J.-J. Do Contrato Social, p.141

174 Idem, p.141.

175 Ibidem, p.142.

${ }^{176}$ Ibidem, p.142. Vários estudiosos do pensamento político de Rousseau chamaram a atenção para o fato de que o filósofo em sua crítica ao cristianismo se inspirou visivelmente em Maquiavel. Derathé, por exemplo, em seu texto " La religion civile selon Rousseau », p.164, faz a seguinte afirmação: "Rousseau n’emprunte pas seulement au Florentin l'idée que le christianisme détache les hommes de leurs intérêts
} 
Toda a crítica ao cristianismo gira em torno daquela principal, que é ter em vista um outro mundo. Isso faz não só com que um cidadão não enobreça sua pátria, lutando com vontade de vencer numa guerra, por exemplo, mas também faz com que ele se conforme e aceite qualquer condição desvantajosa ou até mesmo injusta: “(...) que importa ser livre ou escravo neste vale de misérias?”177 “Os verdadeiros cristãos são feitos para ser escravos; sabem-no e não se comovem absolutamente, porquanto esta vida curta pouco preço apresenta a seus olhos.”"178

Rousseau satiriza os cristãos ao apresentar uma imagem destes numa guerra estrangeira tendo como inimigos espartanos e romanos: “os cristãos piedosos serão dominados, esmagados, destruídos, antes de conseguirem tempo de se dar conta, ou, então, deverão sua salvação somente ao desprezo que o inimigo lhes dedicar." ${ }^{179}$ Contra a opinião comum de que os as tropas cristãs são excelentes, o filósofo diz: "Que me mostrem tropas tais. Quanto a mim, não conheço absolutamente tropas cristãs. Poderão citar-me as cruzadas. Sem discutir o valor dos cruzados, observai que, bem longe de serem cristãos, eram soldados do padre, cidadãos da Igreja; batiam-se por seu país espiritual que ela, não se sabe como, tinha tornado temporal.”180

A posição de Warburton ${ }^{181}$ e a de Bayle ${ }^{182}$ são rejeitadas por Rousseau. O primeiro defende o cristianismo como o mais forte apoio de um corpo político; já o segundo não vê utilidade na religião. Dizer que um corpo político não necessita de religião seria desprezar a própria história: “(...) poder-se-ia provar que jamais se fundou qualquer Estado cuja base não fosse a religião (...).”183 Por outro lado, afirmar que o

terrestres, c'est aussi sous son influence qu'il le représente comme une religion favorable à la tyrannie. » Além disso, esse autor acredita que a apologia de Rousseau ao paganismo também tenha se dado em função de o filósofo ter se lembrado de uma fórmula do Discurso sobre a primeira década de Tito-Lívio “(liv. I, chap.XI): 'La religion introduite par Numa fut une des principales causes de la prospérité de Rome.’ " p.165.

${ }^{177}$ Rousseau, J.-J. Do Contrato Social, p.142.

${ }^{178}$ Idem, p.143.

${ }^{179}$ Ibidem, p.142-143.

${ }^{180}$ Ibidem, p.143.

${ }^{181}$ Rousseau já havia mencionado-o no capítulo sobre o legislador (VII, livro II). Trata-se, segundo Derathé (Du Contrat Social, Notes et Variantes, p.1464. Paris : Gallimard, 1964), de William Warburton (1698-1779), bispo de Gloucester, que tem duas obras que tratam das relações entre Igreja e Estado: no francês, Dissertations sur l'union de la religion, de la morale et de la politique e La Démonstration de la mission divine de Moïse. Já Halbwachs reproduz um trecho da primeira obra, o qual citamos aqui uma pequena parte: “(...) l'autorité de la religion est de nécessité absolue pour assurer l’observation des devoirs et maintenir lê gouvernement civil ...' (...).”Du Contrat Social, p.438, Commentaire.

${ }^{182}$ Para Derathé, Rousseau segue “manisfestement” Montesquieu, Esprit des lois (livre XXIV, chapitre VI: “ 'M. Bayle, après avoir insulté toutes lês religions, flétrit la religion chrétienne; il ose avancer que de véritables chrétiens ne formeroient pas un Etat qui pût subsister’”) ao refutar Bayle. Ele quer dizer com isso que a influência não é direta. Du Contrat Social, p.1502, nota 1 da página 464.

${ }^{183}$ Rousseau, J.-J. Do Contrato Social, p.140. 
cristianismo é a religião ideal não é possível, tendo em vista os aspectos negativos que ela apresenta, os quais mencionamos há pouco ${ }^{184}$. Além disso, também aqui a história é chamada para dar seu depoimento sobre os insucessos com o aparecimento do cristianismo: Jesus, ao estabelecer na terra um reino espiritual, “separando, de tal sorte, o sistema teológico do político, fez que o Estado deixasse de ser uno e determinou as divisões intestinas que jamais deixaram de agitar os povos cristãos.”185

O Estado não pode ficar sem religião ${ }^{186}$ - veremos que Rousseau faz esta afirmação em outros escritos, deixando clara sua posição a respeito desse assunto -, seja porque nunca se viu um Estado que não tivesse sido fundado nela, seja porque ela é um instrumento necessário à boa constituição do corpo político. Essa religião, porém, não pode ser nem o cristianismo nem a religião do cidadão integrais. Logo, a religião civil, que reúne as vantagens de cada uma dessas religiões, é uma tentativa de solucionar o problema - ao menos esta é a pretensão de Rousseau, que, aliás, será criticada por muitos comentadores ${ }^{187}$.

Compõem a religião proposta por Rousseau alguns dogmas positivos, a saber, “a existência da Divindade poderosa, inteligente, benfazeja, previdente e provisora; a vida futura; a felicidade dos justos; o castigo dos maus; a santidade do contrato e das leis”188, e o dogma negativo: “a intolerância”189. Halbwachs, que reúne tais dogmas como sendo três positivos e um negativo, acredita que é sob o primeiro (Deus, a Providência) que os outros dois (a imortalidade, a recompensa dos bons, o castigo dos maus e a santidade das leis) repousam. ${ }^{190}$ Falaremos, em outro tópico, sobre esses dogmas "indispensáveis à manutenção da cidade”191.

Na religião pagã há um único poder, e é a este que os cidadãos devem obediência. Essa religião “é uma espécie de teocracia, na qual não se deve de modo

\footnotetext{
${ }^{184}$ Tais aspectos são as justificativas daquela conclusão apresentada anteriormente: “(...) a lei cristã, no fundo, é mais prejudicial do que útil à firme constituição do Estado”. Idem, p.140.

185 Ibidem, p.139.

${ }^{186}$ Na primeira versão do Contrato Social, por exemplo, Rousseau diz: "Sitôt que les hommes vivent en société il leur faut une Religion qui les y maintienne. Jamais peuple n'a subsisté ni ne subsistera sans Religion et si on ne lui en donnoit point, de lui-même il s'en feroit une ou seroit bientôt détruit. » $D u$ Contrat Social (Ie version), p.336.

${ }^{187}$ Só para citar alguns, Derathé, Vaughan e Masson. O primeiro chama a atenção para os perigos da teoria de Rousseau ("La religion civile selon Rousseau”, p.161). Sabemos da posição do segundo por meio de Halbwachs, que nos informa que aquele "condamne cette cruelle doctrine" (Du Contrat Social, p.428, nota 388). Masson diz: "Et il semblerait que toute la religion du Contrat dût aboutir à la plus féroce et à la plus inquisitoriale des intolérances (...). » La religion de J.-J Rousseau, t.II, p.180.

${ }^{188}$ Rousseau, J.-J. Do Contrato Social, p.144.

189 Idem, p.144.

${ }^{190}$ Halbwachs, M. Du Contrat Social, p.443-444, Commentaire.

${ }^{191}$ Idem, p. 443, Commentaire.
} 
algum ter outro pontífice que não o príncipe, nem outros padres além dos magistrados.” 192 Já o cristianismo dividiu os poderes, em espiritual e temporal, o que cria um grande problema, sobretudo quando aquele que detém um desses poderes tem uma moral incompatível com a do que detém o outro poder: normalmente a Igreja, representada na figura do pontífice, ou do padre, e o Estado, ou soberano, representado pelo governante. Disso resulta a impossibilidade de ser devoto e cidadão ao mesmo tempo.

Rousseau recorre à História para mostrar como os dois poderes podem estar aparentemente reunidos em uma única pessoa, quando na verdade há “dois poderes e dois soberanos”. Ele relata que o fato de os reis da Inglaterra, assim como os czares, terem alcançado o título de chefes da Igreja, com isso tornaram-se, porém, “menos seus senhores do que seus ministros, adquiriram menos o direito de mudá-la do que o poder de mantê-la, não são nela legisladores, mas somente príncipes.”193

Hobbes, segundo Rousseau, apresentou - seu mérito, inclusive, encontra-se aí uma solução para o problema da divisão dos poderes: “De todos os autores cristãos, o filósofo Hobbes é o único que viu muito bem o mal e o remédio, que ousou propor a reunião das duas cabeças da águia, e reconduzir-se tudo à unidade política, sem a qual jamais serão bem constituídos o Estado e o Governo” ${ }^{194}$. Tal solução, no entanto, foi repudiada por muitos, sobretudo pelos partidários do cristianismo: "Não foi tanto o que há de horrível e de falso na sua política, senão o que nela existe de justo e verdadeiro, que a tornou odiosa.”,195

Logo após a conclusão da última frase acima - é o final de um parágrafo -, Rousseau acrescenta uma nota indicando-nos a que obra de Hobbes ele se refere ao fazer o elogio a este: trata-se do De Cive. Tanto Derathé quanto Halbwachs, em suas notas e comentários do capítulo VIII, reproduzem trechos deste escrito ${ }^{196}$ que nos situam na discussão. Hobbes pretende que os dois poderes, o eclesiástico e o civil, estejam reunidos no braço secular ou na potência política ${ }^{197}$. Isto significa que o chefe

\footnotetext{
192 Rousseau, J.-J. Do Contrato Social, p.141.

193 Idem, p. 140.

194 Ibidem, p.140.

195 Ibidem, p.140.

${ }^{196}$ Há trechos dos capítulos XV, XII (citados por Halbwachs), VI e XVII (citados por Derathé).

197 Derathé, R. Du Contrat Social, p.1501, nota 2 da página 463: “ 'Dans les Estats Chrestiens le jugement tant des choses Spirituelles que des temporelles appartient au bras seculier ou à la puissance politique ; de sorte que l'assemblée souveraine, ou le Prince souverain est le chef de l'Eglise, aussi bien que celuy de l'Estat : car l'Eglise et la Republique Chrestienne ne sont au fond qu'une mesme chose.' »
} 
da Igreja deve ser o mesmo que o chefe do Estado, evitando-se desta maneira que surja incompatibilidade em certos julgamentos.

A religião civil defendida por Rousseau também reúne “as duas cabeças da águia”198, já que é o soberano (o povo) quem deverá fixar os dogmas dessa religião, fazendo estes, dessa forma, parte da legislação, e punir ${ }^{199}$ aqueles que agirem em desacordo com tais dogmas. Os cidadãos deverão não somente acreditar nos artigos de fé, mas conduzir-se em concordância com esses.

A introdução da religião civil não poderia contradizer a teoria do contrato social. A soberania é inalienável e indivisível. Logo, atribuir o poder espiritual à Igreja e o poder temporal ao Estado seria dividir o poder que deve ser uno. Mas o que é pior é que a Igreja tem uma moral que conflita com a moral do Estado. Por isso é que Rousseau só retira do cristianismo, mesmo assim tendo os dogmas dessa religião que passar pelo crivo da razão, aquilo que interessa à prática. Os homens têm total liberdade para crer nos outros dogmas, mas com uma condição: desde que esses não contrariem seus deveres como cidadãos. ${ }^{200}$

Estamos falando de uma sociedade política que acabou de se formar - daí termos destacado o termo “origem” em itálico no primeiro parágrafo deste capítulo; os cidadãos não estão convencidos das vantagens das leis, assim, precisam de um motivo que os leve a agir em conformidade com o bem comum, por isso precisam crer nos dogmas da religião civil. A crença em tais dogmas parece determinar a ação de cada um: "Sem obrigar ninguém a crer neles, pode banir do Estado todos os que neles não acreditarem (...)”201. É preciso que a conduta corresponda à crença, pois não adianta professar os dogmas e a atitude ser oposta a eles. Deve haver uma concordância entre pensar, dizer e agir.

Até que o Legislador consiga "mudar a natureza humana”; enquanto a "obra da instituição” estiver em construção; enquanto o homem não for aquilo que ele deverá tornar-se depois das leis, a maioria deve ser guiada pelas crenças, que inspiram "o respeito ao dever, a obediência às leis, o amor ao próximo.”202 Infringir a lei implica

\footnotetext{
${ }^{198}$ Como observa Derathé: “Ce qui domine dans cette conception de la religion civile, c’est le souci de ne pas séparer la communauté religieuse et la communauté politique, et de faire en sorte que les citoyens relèvent d'une seule autorité. » « La religion civile selon Rousseau », p.169.

${ }^{199}$ Lembremo-nos que cabe ao governo, que representa o poder executivo, esta tarefa.

${ }^{200}$ Veremos mais detidamente no capítulo III por que Rousseau rejeita o cristianismo como instituição política, mas aceita-o, ainda que com restrições, como religião do gênero humano.

${ }^{201}$ Rousseau, J.-J. Do Contrato Social, p.144.

${ }^{202}$ Gouhier, H. Les méditations métaphysiques de Jean-Jacques Roussseau, p. 255: « (...) le respect du devoir, l'obéissance aux lois, l'amour du prochain. »
} 
punição, mas o que se faz ao introduzir a religião no Estado, que acrescenta força extra àquela, é impedir que se desvie da lei. Portanto, desprezar os dogmas da religião civil é o mesmo que desprezar as leis, daí Rousseau afirmar que aqueles que não acreditarem em tais dogmas poderão ser banidos do Estado "não como ímpios, mas como insociáveis, como incapazes de amar sinceramente as leis, a justiça, e de imolar, sempre que necessário, sua vida a seu dever.”203

A interpretação de Maurice Halbwachs é que "pouco importa o pensamento que nós temos de Deus, da imortalidade, da relação que as leis têm com Deus: basta que nossa conduta seja tal que ela manifeste que cremos em Deus, na imortalidade, na santidade das leis”, e conclui que "tudo isso não é encarado senão na sua relação com nossos atos, e não se pode exigir de nós alguma outra precisão.” ${ }^{204}$ Será que pouco importa crermos ou não? No trecho "Sem obrigar ninguém a crer neles, pode banir do Estado todos os que neles não acreditarem (...)”não parece estar dito isto. É verdade que ninguém será obrigado a crer nos dogmas; a adesão deve ser voluntária. No entanto, está prevista punição para aquele que não acreditar nos dogmas: a expulsão do Estado $^{205}$. E há uma outra punição para os que se conduzirem como se não cressem em tais dogmas, que é a pena de morte. Na verdade essa última punição nada mais é do que a repressão que atua sobre aqueles que infringem a lei, prevista no modo como a sociedade política é concebida. Isso porque a religião prega - implicitamente - que a lei deve ser obedecida, já que ela é santa. Logo, alguém que age contrariamente à religião age contrariamente à lei, por isso que ao invés de ímpio o cidadão é considerado insociável - foi incapaz de respeitar as normas sociais. Se, no entanto, só a conduta, que revela a crença, importasse, como sugere o comentador, os que agissem em desconformidade com os dogmas seriam punidos com a morte. E a outra punição (a expulsão do Estado), diria respeito a que comportamento?

Antes da publicação do Contrato Rousseau defendia a liberdade de consciência: "Mas, assim como vós, fico indignado com o fato de que não se conceda a cada um

\footnotetext{
${ }^{203}$ Rousseau, J.-J. Do Contrato Social, p.144. É interessante a observação de Gouhier em Les méditations métaphysiques de Jean-Jacques Roussseau, p. 255: «(...) l'existence d'un Dieu intelligent et bon, l'immortalité de l'âme et l'idée d'une justice éternelle ne sont pas inscrites dans la profession de foi civile en tant que vérités chrétiennes mais en tant que croyances politiquement requises pour constituer une morale civique dans une société régie par un pacte raisonnable. »

${ }^{204}$ Halbwachs, M. Du Contrat Social, p.444, Commentaire.

${ }^{205}$ Sobre a não obrigação à crença mas a punição no caso de não se acreditar nos dogmas da religião civil, Derathé comenta: "Par là Rousseau veut exclure les convertisseurs et préserver la liberté de conscience, de manière singulière, il est vrai, puisque les réfractaires seront bannis de l’État. » Derathé, R. Du Contrat Social, p.1505, nota 2 da página 468.
} 
mais perfeita liberdade para dividir sua fé, que o homem ouse controlar o interior das consciências onde não poderia penetrar; como se dependesse de nós crer ou não crer em matérias nas quais a demonstração não tem lugar, e que se pudesse algum dia escravizar a razão à autoridade. Têm, então, os reis deste mundo alguma visão do outro? E têm eles o direito de atormentar seus súditos aqui na Terra para forçá-los a ir para o Paraíso? Não, todo governo humano limita-se por sua natureza aos deveres civis; e, não importa o que possa ter dito o sofista Hobbes, quando um homem serve bem ao Estado, não deve prestar contas a ninguém da maneira como serve a Deus.” 206 Talvez seu pensamento tenha mudado, e, ao propor a punição àqueles que não acreditam nos dogmas, parece insinuar a inspeção das consciências, como o faz explicitamente na Carta a Christophe de Beaumont: "Por que teria um homem o direito de inspecionar a crença de outro, e o Estado, o de inspecionar a crença dos cidadãos? É porque se assume que a crença dos homens determina sua moral, e que das idéias que têm sobre a vida futura depende sua conduta nesta. Se não fosse assim, que diferença faria que cressem ou apenas fingissem crer? A aparência da religião serve apenas para dispensá-los de terem uma.” 207 Afinal, não é o próprio Rousseau que afirma ser "impossível ser bom cidadão ou súdito fiel” sem os sentimentos de sociabilidade?

A figura de um Deus benfeitor e a possibilidade de uma vida para além da terrena é essencial na aceitação dos riscos e até mesmo das perdas que o contrato possa apresentar: "O tratado social tem como fim a conservação dos contratantes. Quem deseja os fins, também deseja os meios, e tais meios são inseparáveis de alguns riscos e, até, de algumas perdas. Quem deseja conservar sua vida à custa dos outros, também deve dá-la por eles quando necessário. Ora, o cidadão não é mais juiz do perigo ao qual a lei quer que se exponha e, quando o príncipe lhe diz: 'É útil ao Estado que morras', deve morrer, pois foi exatamente por essa condição que até então viveu em segurança e que sua vida não é mais mera dádiva da natureza, porém um dom condicional do Estado.”208 Caso não se receba a punição ou a recompensa devidas nesta vida, numa outra elas são garantidas, isto é, os justos poderão ser felizes e os maus castigados ${ }^{209}$.

Rousseau não critica o cristianismo por esta ser uma religião “preocupada unicamente com as coisas do céu”? Poderíamos ser levados a pensar que os dogmas da

\footnotetext{
${ }^{206}$ Rousseau, J-J. Carta de J.-J. Rousseau ao Senhor de Voltaire, p.134.

${ }^{207}$ Rousseau, J.-J. Carta a Christophe de Beaumont, p.84.

${ }^{208}$ Rousseau, J.-J. Do Contrato Social, p. 52.

${ }^{209}$ Na primeira versão do Contrato, p. 336, Rousseau diz: "Dans tout etat qui peut exiger de ses membres le sacrifice de leur vie celui qui ne croit point de vie à venir est nécessairement un lâche ou un fou (...). »
} 
religião civil sobre a existência de Deus e a vida futura também poderiam limitar a ação do cidadão na sociedade ${ }^{210}$; ao contrário, ele deve ser motivado por tais dogmas a cumprir tudo aquilo que o Estado acredita ser importante para sua ascensão. Porém, que diferença há entre a "felicidade dos justos" e o paraíso? Aquele dogma não serve de consolo tanto quanto o do cristianismo? Sim, mas Rousseau “procurará na fé religiosa não somente uma consolação, mas sobretudo uma exortação à prática do bem, 'um encorajamento à virtude’ (...).”211

A sociedade política é fruto de um contrato e este é em si sagrado. Sagrado não porque assim Deus o quer, mas antes porque respeita certos direitos - o poder criado que regula essa sociedade leva em conta os direitos naturais do homem, de modo que nenhum possa ser beneficiado mais do que outro nesse estabelecimento, conforme vimos no capítulo I. Da mesma forma a lei, que é sagrada simplesmente pelo fato de transcender a natureza humana; ela é o resultado de uma operação intelectual que capta a natureza das coisas. Embora, portanto, a sociedade não se funde na religião ${ }^{212}$, nem as leis civis sejam produto da vontade divina, o povo deve ser persuadido de que tanto uma como a outra são conformes à vontade de Deus.

Para que se consiga alcançar uma condição não igual mas ao menos análoga àquela que o homem usufruía na origem ${ }^{213}$, deve-se seguir a vontade geral. É só ela que, representada na forma da lei, pode garantir a liberdade. É somente a subordinação do indivíduo à comunidade que pode manter a ordem civil. A religião civil é chamada para persuadir o povo de que assim deve ser, e, ainda que acreditem que essa é a vontade de Deus, o que importa é que sejam levados a cumprir as leis.

Pierre Masson, no capítulo "Le problème de la religion civile”, afirma que, "para um leitor do Contrato que penetrou nos primeiros capítulos e que acredita ter compreendido a doutrina lá exposta, o recurso formal à religião não deixa de ser uma

\footnotetext{
${ }^{210}$ Rousseau vai dizer que o cristão não se nega a cumprir seu dever, mas o faz com uma "indiferença profunda quanto ao bom ou mau sucesso de seus trabalhos.” Além disso, o filósofo afirma que jamais cristãos fariam um juramento de voltar vencedores de uma guerra, pois "acreditariam estar tentando a Deus.” Ibidem, p. 142-143.

${ }^{211}$ Derathé, R. "Les rapports de la morale et de la religion chez Jean-Jacques Rousseau”, p.172 : «Il cherchera dans la foi religieuse non pas seulement une consolation, mais surtout une exhortation à bien faire, 'un encouragement à la vertu' (...). »

212 “(...) la religion civile n’est pas le fondement de la société politique. Celli-ci reçoit son être du contrat. Mais la croyance aux dogmes de la religion civile est une condition nécessaire quant au sentiment, du maintien de cette société juste; il faut y croire pour se conduire en citoyen, et faire face aux obligations lês plus graves, en particulier pour exposer s avie afin de défendre l’État.” Halbwachs, M. Du Contrat Social, p.444, Commentaire.

${ }^{213}$ Essa é a interpretação de alguns comentadores frente à proposta do Contrato Social, por exemplo Sergio Cotta, o qual citamos no capítulo I.
} 
surpresa.”214 Não concordamos com esta opinião uma vez que Rousseau aponta diversos elementos problemáticos durante a elaboração de seus "princípios políticos” visando mostrar a dificuldade de se estabelecer aquela "regra de administração legítima e segura”. Afinal, ele toma os “homens como são”. Assim, a religião aparece como um complemento, aliás necessário $^{215}$, que apresenta uma solução - Acreditamos ter mostrado os argumentos que justificam a necessidade de uma religião, e portanto a sua função e relevância, ainda que nos falte falar de alguns pontos. O penúltimo capítulo do último livro do Contrato é totalmente compatível com o contexto que nos esforçamos para expor, do modo mais claro possível, no primeiro capítulo.

Em seu artigo "Les rapports de la morale et de la religion chez Jean-Jacques Rousseau” Derathé, reunindo diversas passagens de diversos escritos de Rousseau, sobretudo aquelas da Profissão de fé do vigário saboiano e as das Lettres enviadas a destinatários diversos, afirma não ser possível, no sistema rousseauísta, separar a moral da religião. Rousseau parece apontar a consciência como solução para as paixões do homem, chegando até privilegiá-la frente à razão. Acontece que essas paixões tanto podem fazer a voz da razão calar-se diante delas como a própria consciência ${ }^{216}$. Assim, a religião é que acabaria sendo o remédio mais eficaz.

Rousseau pensou o homem isolado que, em função de certas circunstâncias, necessitou reunir-se com outros e formar uma sociedade politicamente organizada. Acontece que esse homem não tem uma razão suficientemente desenvolvida de modo que possa ser conduzido a reconhecer certas necessidades que são impostas pelo pacto, ao qual ele adere com a intenção de garantir sua sobrevivência. Além disso, ele é naturalmente egoísta, o que exige que ele passe por uma adaptação ao meio social, e tem paixões que normalmente falam mais alto do que qualquer preceito, seja ele derivado da razão ou da consciência.

A liberdade civil - e mesmo a individual, embora não seja esta que nos interessa aqui - só é alcançada quando se consegue colocar a razão ou a consciência à frente das paixões, que têm forte poder de sedução e que faz com que não enxerguemos males distantes. Por isso se diz que aquele que age sob paixão é escravo. A religião é um

\footnotetext{
${ }^{214}$ Masson, P.M. La religion de J.J. Rousseau (chapitre V du livre II : «Le problème de la religion civile », p. 186) : " Pour un lecteur du Contrat, qui s'est pénétre des premiers chapitres, et qui croit en avoir saisi la doctrine, ce recours formel à la religion ne laisse pas d'être une surprise. »

${ }^{215}$ Halbwachs, M. Du Contrat Social, p.444, Commentaire.

216 "Dans la Profession de foi, Rousseau déclare, en effet, que la voix de la conscience risque toujours d'être étouffée par la voix plus bruyante des préjugés, et que, pour la consulter utilement, il faut le faire 'dans le silence des passions.'” Derathé, R. "Les rapports de la morale et de la religion chez Jean-Jacques Rousseau”, p.145.
} 
recurso - exterior - a mais que "força” o cidadão a ser livre, já que ela o persuade de que deve agir de determinada forma em detrimento de outra. Sem o socorro da religião o homem não saberia ser senhor de si e de suas paixões ${ }^{217}$.

Havíamos mencionado que Rousseau pretendia com a religião civil unir aquilo que tanto a religião do homem quanto a religião do cidadão apresentavam de vantajoso. Aliás - como também mostramos ao reproduzir um trecho do Manuscrito de Genebra -, o próprio Rousseau afirma ser esta sua pretensão ao propô-la. Mas vejamos em que sentido ela é a reunião daquelas duas.

A religião civil deve exaltar as leis, mas não deve ter seus deuses próprios e associados àquelas, como era na religião pagã. Ora, o que Rousseau toma emprestado dela é o posto sagrado que as leis lá ocupavam; elas são produto da vontade dos deuses tutelares e desobedecê-las era o mesmo que desobedecer aqueles. O cristianismo não apresenta esse inconveniente do paganismo, ao contrário, defende um só Deus para todos os povos. É esse aspecto da religião do homem que ele retém, além dos dogmas que derivam desse - que professa a existência de um único Deus.

Dos dogmas positivos anunciados na religião civil só a "santidade do contrato e das leis” não se encontra na religião natural desenvolvida na Profissão de fé. Considerase, portanto, a religião civil como "um compromisso que é a simples justaposição dos artigos de fé do Vigário saboiano e de um dogma estritamente civil, 'a santidade do contrato e das leis." „218 A religião do Vigário apóia-se no Evangelho, mas não repousa sobre a revelação, como é o caso do cristianismo. Logo, a religião do homem é a religião do Vigário somente enquanto essa última coincide com o cristianismo.

Já que os dogmas positivos religiosos ${ }^{219}$ correspondem àqueles enunciados na religião natural, falaremos um pouco dessa religião. Rousseau afirma no Contrato: “Os dogmas da religião civil devem ser simples, em pequeno número, enunciados com

\footnotetext{
${ }^{217}$ Idem, p.148.

${ }^{218}$ Derathé, R. «La religion civile selon Rousseau », p. 165: «(...) un compromis qui est la simple juxtaposition des articles de foi du Vicaire savoyard et d'un dogme strictement civil, «la sainteté du contrat social et des lois. » Para Henri Gouhier, « Rousseau emploie l'expression 'profession de foi' mais dans une perspective politique. La future 'religion naturelle' du Vicaire et la future 'religion civile' du Législateur apparaissent mêlées à l'interieur d'un même projet. » Les méditations métaphysiques de JeanJacques Roussseau, p.248

${ }^{219}$ Derathé, R. Du Contrat Social, p.1505, nota 6 da página 468. Albert Schinz utiliza "dogmas teológicos". Ele critica Rousseau por este ter empregado termos "vraiment peu heureux" - se refere aos "sentimentos de sociabilidade" - sendo que há entre os dogmas os que são "teológicos". La pensée de Jean-Jacques Rousseau, p.372. Henri Gouhier nota que: “(...) l'existence d'un Dieu intelligent et bon, l'immortalité de l'âme et l'idée d'une justice éternelle ne sont pas inscrites dans la profession de foi civile em tant que vérités chrétiennes mais en tant que croyances politiquement requises pour constituer une morale civique dans une société régie par un pacte raisonnable. » Les méditations métaphysiques de JeanJacques Roussseau, p.255.
} 
precisão, sem explicações ou comentários.”220 Na Profissão de fé, no entanto, eles recebem "explicações” e “comentários”, e esse é o motivo principal que nos leva a examinar a religião natural do Vigário saboiano. Antes de iniciarmos essa tarefa, no entanto, faremos mais algumas observações acerca da religião civil.

Como vimos, a religião civil retém algo da religião do cidadão - religião pagã e algo da religião do homem - cristianismo. Esse algo que ela retém dessa segunda religião são conteúdos que interessam à prática e que não contrariam a razão. Rousseau admite certos dogmas do cristianismo, que compõem parte da religião civil, não porque eles foram revelados, mas porque ele próprio alcançou essas verdades - isso ficará mais claro no próximo tópico. A religião natural, portanto, apóia-se no Evangelho, mas só aceita dele aquilo que pode exercer influência sobre nossa conduta e, principalmente, aquilo que não for contrário à razão.

\subsection{A religião natural}

Realmente Rousseau não fala, na Profissão de fé, “da santidade das leis, nem das leis da sociedade ${ }^{221}$, nem da sociedade.” ${ }^{222}$ No entanto, a preocupação de Rousseau é educar Emílio para viver em sociedade: "Emílio não foi feito para permanecer sempre solitário; membro da sociedade, deve cumprir seus deveres." ${ }^{\text {„23 }}$ Se não fosse assim, e se Emílio fosse viver isolado até o fim de sua vida, o filósofo - por meio do personagem Vigário saboiano ${ }^{224}$ - não teria feito o discípulo acompanhar uma exposição - que é o que faz na Profissão de fé - em que as verdades que interessam à prática são apresentadas, já que tira de tais verdades as máximas que devem guiar sua conduta e também tira delas as regras que deve prescrever a si mesmo para cumprir sua destinação

\footnotetext{
${ }^{220}$ Rousseau, J.-J. Do Contrato Social, p.144. Os grifos são nossos.

${ }^{221}$ Na página 443 da Profissão de fé, porém, Rousseau fala em ordem pública e obediência às leis: "Acho que solicitar alguém a deixar a religião em que nasceu é solicitar-lhe que aja mal e, por conseguinte, é agir mal. Na espera de maiores luzes, conservemos a ordem pública; respeitemos as leis em todos os lugares, não perturbemos o culto que elas prescrevem; não levemos os cidadãos à desobediência, pois não sabemos com certeza se é um bem para eles trocar suas opiniões por outras, e sabemos com certeza que é um mal desobedecer às leis."

${ }^{222}$ Halbwachs, M. Du Contrat Social, p.444, Commentaire.

${ }^{223}$ Rousseau, J.-J. Profissão de fé, p.470.

${ }^{224}$ Somente como curiosidade, na Carta a Christophe de Beaumont Rousseau, indiretamente, diz que o Vigário não é só um personagem, isto é, ele teria existido de fato: “Observo de passagem que esta é a segunda vez em que o senhor qualifica o padre saboiano de personagem quimérico ou suposto. Diga-me como sabe disso, eu lhe peço.” P.66.
} 
na terra. ${ }^{225}$ Além disso, Rousseau quer mostrar que, apesar de tudo, vale a pena ser virtuoso. A justiça, por exemplo, é uma virtude, e só faz sentido falar em justiça em sociedade, pois ela implica uma relação. Só posso ser justo com respeito a outrem.

Ainda que se tenha na Profissão de fé um contexto diferente, um sistema diverso daquele do Contrato, como vimos rapidamente no primeiro capítulo e reforçaremos um pouco neste, a religião também aí é um recurso persuasivo ${ }^{226}$. Um dos motivos que justificam a necessidade de uma religião no quadro político do Contrato é impossibilidade de o indivíduo poder recorrer à sua faculdade racional, que não está suficientemente desenvolvida, para alcançar as regras de sua conduta, ou mesmo ser convencido por alguém - o Legislador, por exemplo - de que uma determinada lei é boa. Emílio também precisa ser persuadido, já que ainda não é capaz de fazer uso pleno de seu intelecto - ao menos na fase em que se encontra, a qual é descrita nesta parte da obra.

Ao modo de Descartes, como ele próprio admite, Rousseau inicia a Profissão de fé justificando a investigação que se sucederá: "Eu estava naquelas disposições de incerteza e de dúvida que Descartes exige para a procura da verdade.”227 Tendo como critérios a razão e a Escritura ${ }^{228}$ - e veremos que há um terceiro critério, sob o qual todos os dogmas são estabelecidos, mas que também não dispensa o uso da razão ${ }^{229}$ - o Vigário pretende, portanto, encontrar a verdade. Mas não qualquer verdade, e sim uma que necessariamente interesse à prática. Dessa busca resultam os artigos de fé.

É importante não somente que nos limitemos a conhecer aquilo que pode ser útil à nossa conduta, mas também devemos saber que nossa razão é limitada, e isso deve ser respeitado $^{230}$. Aliás, Rousseau utiliza esses dois argumentos, além de um outro que diz que tudo o que é contrário à razão não podemos admitir, para justificar sua posição

\footnotetext{
${ }^{225}$ Rousseau, J.-J. Profissão de fé, p.404.

${ }^{226}$ Rousseau escreve em uma nota de rodapé da Profissão de fé: "Nenhum homem segue totalmente a sua religião quando a tem: isso é verdade. A maioria não a tem, e não a segue absolutamente quando a tem: isso também é verdade. Mas, enfim, alguns têm e a seguem pelo menos em parte, e é indubitável que motivos religiosos muitas vezes os impedem de agir mal e obtêm deles virtudes, atos louváveis que não ocorreriam sem tais motivos." p.448.

${ }^{227}$ Idem, p.374.

${ }^{228}$ Veremos que, na verdade, só a razão poderá ser considerada como regra de crença, pois a própria Escritura deve passar pelo seu crivo. Na Carta a Beaumont Rousseau reforça: “(...) tomo a Escritura e a razão como as únicas regras de minha crença; como eles - Rousseau se refere a seus pais -, desafio a autoridade dos homens e concordo em submeter-me a suas fórmulas apenas quando percebo a verdade delas (...).”p.73.

229 'En ce cas, c'est le 'sentiment interieur' qui détermine notre croyance, mais comme nous le verrons, jamais ce sentiment n'agit contre la raison : il nou fait seulement croire ce qu'il n'est pas déraisonnable d’admettre. » Derathé, R. Le rationalisme de Jean-Jacques Rousseau, p.56-57.

${ }^{230}$ Rousseau, J.J. Profissão de fé do vigário saboiano, p.376: “(...) queremos compreender tudo, conhecer tudo. A única coisa que não sabemos é ignorar o que não podemos saber.”
} 
frente a alguns dogmas do cristianismo. Ao defender-se da acusação de ímpio, diz que muitas coisas tidas como verdade pela igreja ele não pode admitir - mas também não pode rejeitar - uma vez que ultrapassam aquilo que sua razão pode alcançar, ou são contrárias a ela ${ }^{231}$. Por outro lado, aquilo que considera fundamental para as nossas ações, pois pode determiná-las, deve ser aceito mesmo que não possa ser demonstrado pela razão. Isso não quer dizer, no entanto, que algo que a contrarie possa ser estabelecido. É aí que entra o que Rousseau chama de sentimento interior, que é outro meio de se alcançar certas verdades.

Rousseau denomina essa atitude de não admissão e ao mesmo tempo de não rejeição de certos postulados do cristianismo “ceticismo involuntário”. Tudo o que vai além dos limites do entendimento humano não deve ser admitido nem rejeitado. Mas ele acredita que tal ceticismo “não se estende aos pontos essenciais da prática.”232 “Assim, o conhecimento da verdade só é indispensável ao homem na medida em que ele deve retirar daí um proveito moral, e os limites em que a natureza barrou nosso entendimento não o impedem de cumprir sua destinação, já que ele nos fornece todas as verdades que nos importa conhecer.”233

A Escritura é outro meio pelo qual podemos chegar a certos conhecimentos, mas esse critério não dispensa o entendimento, ao contrário. Isso significa que, mesmo em se tratando de algo considerado sagrado, pode-se rejeitar qualquer conteúdo dela que não possa ser alcançado pelo entendimento. "Não se trata portanto de aceitar cegamente e ao máximo tudo que contém a Escritura, mas pertence à nossa razão discernir o que os homens acrescentaram ao texto sagrado do que vem realmente de Deus.” 234 Para Rousseau, só a razão pode garantir a autenticidade da Bíblia; só ela é um meio legítimo e seguro, pois confirma se certa doutrina ensinada é verdadeira ou não ${ }^{235}$. Assim, se a aceitação dos conteúdos da Escritura depende do exame que deve ser feito pela razão,

\footnotetext{
${ }^{231}$ Veremos que alguns preceitos que contém no Evangelho Rousseau não os admite, mas também não os rejeita, e justifica essa postura dizendo que ultrapassam aquilo que sua razão pode conhecer; sua atitude, então, é manter uma "dúvida respeitosa". Outros, no entanto, ele rejeita, justificando que sua razão o obriga a fazê-lo, já que são contrários a ela. Falaremos mais deste ponto no terceiro capítulo.

${ }^{232}$ Rousseau, J.J. Profissão de fé do vigário saboiano, p.441.

${ }^{233}$ Derathé, R. Le rationalisme de Jean-Jacques Rousseau, p.45: « Ainsi la connaissance de la vérité n’est indispensable à l'homme que dans la mesure où il doit en retirer un profit moral et les bornes où la nature a enfermé notre entendement ne l'empêchent pas de remplir sa destination , puisqu'il nous fournit toutes les vérités qu'il nous importe de connaître. »

${ }^{234}$ Idem, p.54: «Il ne s'agit donc pas d'accepter aveuglément et en bloc tout ce que contient l'Écriture, mais il appartient à notre raison de discerner ce que les hommes ont ajouté au texte sacré de ce qui vient réellement de Dieu. »

${ }^{235}$ Ibidem, p.55. A doutrina é verdadeira quando ela é conforme a idéia que nossa razão nos dá da divindade.
} 
então somente esta última deve ser considerada como a regra das crenças. Quando dissemos que a religião natural do Vigário não se apóia na revelação ${ }^{236}$ é justamente porque o que determina a crença em certos dogmas é a razão - e também o sentimento interior, que necessita da sua aprovação.

Em sua investigação sobre aqueles conhecimentos que interessam à prática, o Vigário chega ao primeiro dogma, ou primeiro artigo de fé, que é a existência de "uma vontade que move o Universo e ainda a natureza" ${ }^{237}$. Ele admite que tal dogma é obscuro, mas acredita que "nada tem que repugne à razão ou à observação (...)." 238 Ou seja, não se chegou a esse resultado por meio da razão, porém, ele pode ser aceito uma vez que não a contraria. O critério que estabeleceu esse primeiro artigo de fé é o sentimento interior. Tal critério, portanto, não dispensa o uso da razão, pois embora o Vigário tenha alcançado essa primeira verdade por outro meio, a razão deve ao menos admiti-la, ainda que não possa demonstrá-la.

É também por meio daquele sentimento que o Vigário chega ao segundo artigo de fé: "Se a matéria movida me indica uma vontade, a matéria movida segundo certas leis me indica uma inteligência (...).” ${ }^{239}$ O ser portador dessa vontade e dessa inteligência é Deus: “O ser que quer e que pode, o ser ativo por si mesmo, o ser, enfim, qualquer que seja ele, que move o universo e ordena todas as coisas, chamo-o Deus.” "240

Na Profissão de fé Rousseau não esclarece ao leitor a natureza do sentimento interior ao qual ele frequentemente recorre; em outros escritos é que encontramos uma idéia mais clara sobre o isso. Limitamos-nos aqui, no entanto, a mencionar aquilo que interessa para nossa discussão. A expressão empregada deve ser entendida, no contexto que estamos examinando - pois há três concepções de sentimento interior, e não iremos comentar todas elas -, como uma espécie de fé, de crença. Como nossa razão é limitada, e seria muito violento à nossa alma se tivéssemos que nos manter em um estado de

\footnotetext{
236 "Dans les Lettres écrites de la Montagne (...) Rousseau distingue trois preuves de la révélation. Les envoyés de Dieu sont supérieurs aux autres hommes: $1^{\circ}$ Par leur pouvoir de faire des miracles ; $2^{\circ}$ Par leur qualités morales; et $3^{\circ}$ Par la doctrine même qu'ils enseignent. De ces trois caractères Rousseau ne retient que le dernier. Il rejette formellement le premier, et le second ne lui paraît pas décisif. » Ibidem, p.44-45, nota 4. Porém, o próprio dogma derivado da revelação, para que seja admitido, ele deve corresponder à idéia que nossa razão forma sobre a divindade, como apontamos na nota anterior a essa. Embora, portanto, a religião natural não se apóie na revelação, se um dogma revelado for admitido pela razão, os ensinamentos de Jesus coincidirão com a religião natural.

${ }^{237}$ Rousseau, J.J. Profissão de fé do vigário saboiano, p.384. Não iremos aqui descrever todo o percurso de Rousseau que leva ao estabelecimento dos dogmas; isso exigiria um exame mais cuidadoso da Profissão de fé, incluindo a concepção do filósofo de conhecimento. Limitaremos-nos a apontar aquilo que interessa para nossa discussão.

${ }^{238}$ Idem, p.385.

${ }^{239}$ Ibidem, p.386.

${ }^{240}$ Ibidem, p.390.
} 
dúvida com relação a verdades que nos importa conhecer ${ }^{241}$, já que nosso entendimento não poderia alcançá-las, somos levados pelo sentimento interior a admitir tais verdades: “Graças ao sentimento nós teríamos a possibilidade de afirmar verdades que a razão não nos faria conhecer (...).O apelo ao sentimento interior, entendido nesta acepção, se justificaria pelo limites nos quais a razão se encontra fechada.”242

O sentimento interior, portanto, tem um papel muito importante, pois é ele que possibilita o acesso a coisas que nos importa saber. Ele tem a ver com o método, que o Vigário anuncia nas primeiras páginas da Profissão de fé, que levará ao objetivo estabelecido: “Trazendo pois em mim o amor à verdade como única filosofia, e como único método uma regra fácil e simples que me dispensa da vã sutileza dos argumentos, retomo com essa regra o exame dos conhecimentos que me interessam, decidido a admitir como evidentes todos aqueles a que, na sinceridade de meu coração, não possa recusar meu consentimento, como verdadeiros todos os que me pareçam ter uma ligação necessária com os primeiros e a deixar todos os outros conhecimentos na incerteza, sem rejeitá-los nem admiti-los, e sem me atormentar para esclarecê-los quando não me levem a nada útil para a prática.”243

Pelo sentimento interior chega-se à idéia da existência de Deus e às qualidades a ele atribuídas, e isso é o que é possível conhecer; nem por esse meio, nem pelo raciocínio consegue-se ir além disso: “Junto a esse nome (ele se refere a "Deus”) as idéias de inteligência, de potência, de vontade, que reuni, e mais a de bondade que é uma conseqüência necessária das primeiras; mas nem por isso conheço melhor o ser a que dei esse nome; ele se furta igualmente aos meus sentidos e ao meu entendimento; quanto mais penso nele, mais me confundo; sei com toda a certeza que ele existe, e que existe por si mesmo; sei que minha existência é subordinada à sua e que todas as coisas que conheço estão absolutamente no mesmo caso.” ${ }^{244}$ O sentimento interior nos leva ao conhecimento de verdades que não teríamos acesso pela razão; assim, não deixa que permaneçamos num estado violento de dúvida. Mas vale ressaltar que não temos, com

\footnotetext{
${ }^{241}$ Rousseau declara na Carta a Voltaire: “(...) creio em Deus tão fortemente quanto em qualquer outra verdade, porque crer e não crer são coisas que menos dependem de mim; porque o estado de dúvida é um estado violento para minha alma; porque, quando minha razão divaga, minha fé não pode permanecer muito tempo em suspenso e se determina sem ela; enfim, porque mil questões me atraem de preferência para o lado mais consolador, e juntam o peso da esperança ao equilíbrio da razão.” P.132-133.

${ }^{242}$ Derathé, R. Le rationalisme de Jean-Jacques Rousseau, p.64: «Grâce au sentiment nous aurions la possibilité d'affirmer des vérités que la raison ne saurait nous faire connaître (...). L'appel au sentiment intérieur, pris dans cette acception, se justifierait par les limites dand lequelles la raison se trouve enfermée. "

${ }^{243}$ Rousseau, J.J. Profissão de fé do vigário saboiano, p.378.

${ }^{244}$ Idem, p.390.
} 
isso, idéias claras acerca de tais verdades ${ }^{245}$ - que são todos os dogmas estabelecidos pelo Vigário.

O Vigário segue o seu pensamento tendo como próximo objetivo saber que lugar ocupa na ordem das coisas que Deus governa ${ }^{246}$. Chega à conclusão de que, embora seja superior aos animais; embora possa sentir o que é ordem, beleza e virtude; embora possa amar o bem e fazê-lo ${ }^{247}$, quando, para conhecer seu lugar individual em sua espécie, considera as diversas posições sociais e os homens que as ocupam: “Que espetáculo! Onde está a ordem que observei? O quadro da natureza só me oferecia harmonia e proporções, o do gênero humano só me oferece confusão e desordem! O concerto reina entre os elementos e os homens estão no caos! Os animais são felizes, só seu rei é miserável! Ó sabedoria, onde estão tuas leis? Ó providência, assim regerá o mundo? Ser beneficente, em que se transformou teu poder? Vejo o mal sobre a terra.”248 Essa discussão tem tudo a ver com aquela presente no segundo Discurso: o homem é bom naturalmente e torna-se mau ao viver em sociedade. O Vigário ocupa o lugar do filósofo do Discurso sobre a desigualdade que nos apresenta o homem abstrato despido de tudo aquilo que lhe é acrescentado quando passa a relacionar-se com os outros homens. O “quadro da natureza” que o Vigário de Sabóia menciona é aquele em que o homem natural, que vive naquele primeiro estado de natureza, está inserido, e que muito distante está do homem civilizado, ou do “rei miserável”. A natureza que conhecemos pela razão não corresponde a atual realidade; isso porque ela foi transformada. Essa observação leva-o a estabelecer a dualidade da natureza humana em espírito e matéria. Só essa dualidade pode dar conta de explicar por que o homem causa o mal, a si mesmo ou a outrem, sendo que poderia fazer o contrário. A possibilidade de fazer o bem está associada à alma; o desvio do bem só pode ser causado pelas paixões, que são a voz do corpo.

Se o homem criou ele mesmo uma condição desfavorável para si, não foi por escolha, porque a liberdade lhe foi conferida para que escolhesse o melhor, e não pode ser de outra forma. Então, algumas coisas seduziram-no de tal forma que se tornou escravo ao não resistir a elas: "Não, o homem não é outro; eu quero e não quero, sinto-

\footnotetext{
${ }^{245}$ Derathé, R. Le rationalisme de Jean-Jacques Rousseau, p.71: «Ce n’est pas de rendre claires ces notions obscures de notre entendement, c'est de nous permettre d'y donner notre adhésion. »

${ }^{246}$ Rousseau, J.J. Profissão de fé do vigário saboiano, p.390.

247 Idem, p.391.

248 Ibidem, p.392.
} 
me ao mesmo tempo escravo e liberto; vejo o bem, amo-o, e faço o mal; sou ativo quando escuto a razão, passivo quando minhas paixões me arrastam (...).”249

É a faculdade racional de que dispõe o homem que o leva a formar o juízo sobre o bem, fazendo com que ele possa escolher tal bem. Mas se ocorre um erro na operação de julgar, o homem escolhe mal, sem saber que o fez, é verdade, pois acredita ter escolhido o bem. "Quando me perguntam qual é a causa que determina minha vontade, pergunto por minha vez qual é a causa que determina meu juízo, pois é claro que essas duas causas são apenas uma, e, quando se compreende bem que o homem é ativo em seus juízos, que seu entendimento é apenas o poder de comparar e de julgar, vê-se que sua altivez não passa de um poder semelhante ou derivado daquele; ele escolhe o bom como julgou o verdadeiro; se julga falsamente, escolhe mal. Qual é, então, a causa que determina sua vontade? É o seu juízo. E qual é a causa que determina seu juízo? É sua faculdade inteligente, é sua potência de julgar; a sua determinante está nele mesmo.”²50

Formar um juízo verdadeiro sobre algo, no entanto, não garante que o homem dirija sua vontade a ele; isso porque alguma paixão pode causar um desvio, fazendo com que ele ceda a essa paixão. Significa, então, que ele deixou de escolher o bem verdadeiro e escolheu um que, no máximo, é um bem aparente? Não. Ao ser afetado com certa intensidade por algum objeto externo foi impedido de escolher. “(...) consinto ou resisto, sucumbo ou sou vencedor, e sinto perfeitamente em mim mesmo quando faço o que quis fazer ou quando apenas cedo às minhas paixões. Tenho sempre o poder de querer, não a força de executar. Quando me entrego às tentações, ajo conforme o impulso dos objetos externos. Quando me censuro por tal fraqueza, só ouço a minha vontade; sou escravo por meus vícios e livre por meus remorsos; o sentimento de minha liberdade só se apaga em mim quando me depravo e enfim impeço a voz da alma de se elevar contra a lei do corpo.”251

O Vigário associa - tratamos disso no capítulo I também - as paixões à voz do corpo e a consciência à voz da alma. A consciência garante a liberdade, pois se ela for ouvida, o homem consegue resistir às paixões e escolher o bem verdadeiro. É preciso, portanto, que ela fale mais alto do que as paixões e que essas não sejam tão intensas que impossibilitem aquela de se impor.

\footnotetext{
249 Ibidem, p.392.

250 Ibidem, p.395.

${ }^{251}$ Ibidem, p.395.
} 
Nenhum homem deseja e faz o mal a si próprio ${ }^{252}$, mas pode fazê-lo a um outro. Ele é livre neste sentido também, embora Deus tenha-o feito assim para que “fizesse não o mal, mas o bem por escolha”253. É da sua própria natureza garantir o seu bem-estar, mas quando esse zelo por si mesmo se excede, e passa a "fazer mais caso de si mesmo do que de qualquer outro” ${ }^{\text {254 }}$, ele causa o prejuízo a esse. Instrumentos para impedi-lo de praticar o mal contra alguém ele possui: A providência "colocou-o em condições de fazer essa escolha empregando bem as faculdades de que o dotou (...).,”255 Sob uma paixão muito forte, no entanto, ele pode desprezá-los. Mas isso não o isenta da culpa, e por isso receberá a punição devida, que poderá acontecer numa outra vida ou nesta mesmo ${ }^{256}$.

O terceiro artigo de fé diz: “O homem, portanto, é livre em suas ações e, como tal, animado de sua substância imaterial (...).”257 Se ele tender para o lado espiritual, isto é, se ele deixar que a razão dite a maneira como deve conduzir-se, exercerá seu direito à virtude, ${ }^{258}$ e terá um retorno, ainda que este possa acontecer somente numa outra vida. Contudo, se abusar dessa liberdade, deixando a matéria se sobrepor ao espírito, e fizer o mal, este retornará a ele. O homem não pode reclamar com Deus por este não o impedir de praticar o mal. Se fôssemos impedidos disso, por outro lado o mérito não nos seria atribuído caso nossa ação fosse reta: Podia a potência divina "colocar uma contradição em nossa natureza e atribuir o mérito de ter bem agido a quem não tivesse o poder de agir mal? Qual! Para impedir o homem de ser mau dever-se-ia limitá-lo ao instinto e torná-lo um animal? Não, Deus de minha alma, nunca te censurarei por tê-la feito à tua imagem, para que eu pudesse ser livre, bom e feliz como tu."259

Depois de anunciar o terceiro artigo de fé, o Vigário afirma que não enumerará os outros dogmas uma vez que todos eles podem facilmente ser deduzidos dos três primeiros. A imortalidade da alma é um desses dogmas.

\footnotetext{
${ }^{252} \mathrm{Na}$ verdade o homem pode e faz o mal a si próprio, mas não por escolha: ou ele causa o mal a si mesmo porque sua faculdade racional falhou ao operar e ele escolhe o mal acreditando que seja o bem, ou ele vê o bem mas alguma paixão o impede de fazer a escolha. "Se nos contentássemos com ser o que somos, não teríamos de deplorar nossa sorte, mas, para procurar um bem-estar imaginário proporcionamos a nós mesmos mil males reais.” Ibidem, p.397.

${ }^{253}$ Ibidem, p.396.

${ }^{254}$ Rousseau, J.-J. Discurso sobre a desigualdade, p.307.

${ }^{255}$ Rousseau, J.J. Profissão de fé do vigário saboiano, p.396.

${ }^{256}$ O Vigário diz num trecho de sua profissão: "Que necessidade há de procurar o inferno na outra vida? Ele está já nesta vida, no coração dos maus.” Idem, p.402.

${ }^{257}$ Ibidem, p.396.

${ }^{258}$ Deus pôs nas ações dos homens a moralidade que as enobrece e lhes deu direito à virtude. Ibidem, p.396.

${ }^{259}$ Ibidem, p.397.
} 
O Vigário admitiu a imaterialidade da alma quando diferenciou esta do corpo, mas além disso estabelece a sobrevivência dessa alma: "Se a alma é imaterial, ela pode sobreviver ao corpo, e, se sobrevive a ele, a providência está justificada.”260 Embora ele afirme, mais uma vez, mas agora com relação a esse conhecimento, que seu entendimento não pode conceber nada sem limites e que, portanto, está impedido de negar ou afirmar se a alma é imortal, ele presume que ela não morre. Inicialmente, então, o Vigário se limita à crença de que a alma sobrevive "ao corpo o suficiente para a manutenção da ordem; quem sabe", diz ele, "se é o suficiente para durar para sempre?”261 Depois, porém, diz não poder conceber a destruição do ser pensante, e a presunção de que ele não morre vem do fato de o Vigário não poder imaginar como tal ser possa morrer. E conclui: “Já que essa presunção me consola e não tem nada de insensato, por que temeria entregar-me a ela?”262

A importância do dogma da imortalidade da alma é que ele serve de consolo àqueles que fazem o bem e não só não têm um retorno como também continuam numa situação desfavorável, e, além disso, vêem o mau triunfar. Se os bons não podem ter garantia de que serão recompensados nesta vida, tal garantia deve residir numa outra. $\mathrm{O}$ Vigário diz: "Quanto mais volto para dentro de mim mesmo, quanto mais me consulto, mais leio estas palavras escritas em minha alma: Sê justo e serás feliz. Não é assim, porém, se considerarmos o atual estado das coisas; o mau prospera e o justo permanece oprimido.” 263 Assim, diante dessas circunstâncias, a crença numa vida futura é fundamental. Caso não houvesse tal crença, esse “atual estado das coisas” geraria uma revolta e ninguém veria motivo em ser correto.

“Contentamento consigo mesmo” é uma espécie de retorno que receberá aquele que praticar o bem: “(...) é para merecer esse contentamento que fomos colocados na terra e dotados de liberdade, que somos tentados pelas paixões e contidos pela consciência.”"264 O contentamento consigo mesmo gera o “supremo gozo”,265, "a volúpia pura” ${ }^{266}$. Mas antes de reivindicarmos a felicidade, devemos fazer por merecê-la: “Sejamos bons primeiro e depois seremos felizes. Não exijamos o prêmio antes da

\footnotetext{
${ }^{260}$ Ibidem, p.399.

${ }^{261}$ Ibidem, p.400.

262 Ibidem,p.400. Sobre a imortalidade da alma, Rousseau declara a Voltaire que ele tem a "ventura de acreditar sem ignorar que a razão pode dela duvidar (...).” Carta a Voltaire, p.132.

263 Rousseau, J.J. Profissão de fé do vigário saboiano, p.398-399.

${ }^{264}$ Idem, p.397.

265 Ibidem, p.397.

${ }^{266}$ Ibidem, p.401.
} 
vitória, nem o salário antes do trabalho.”267 Será a lembrança, depois da morte, de todas as ações boas que praticamos durante a nossa vida que garantirá nossa felicidade na vida futura: “Ora, não poderia lembrar-me depois de minha morte do que fui durante a vida sem me lembrar também do que senti e, por conseguinte, do que fiz, e não tenho dúvidas de que essa lembrança será um dia a felicidade dos bons e o tormento dos maus.” ${ }^{268}$ Portanto, a causa da felicidade é a mesma que a de seu contrário: a lembrança de nossa história de vida. Assim, cada um deve construir a sua sorte ${ }^{269}$.

Esclarece o Vigário que não devemos falar em recompensa, já que aquele que for virtuoso viverá, numa vida futura, de acordo com a sua natureza: "Não digo que os bons serão recompensados, pois que outro bem pode aguardar um ser excelente a não ser existir de acordo com a sua natureza?”270 No entanto, aquele que sofreu, mesmo não tendo abusado de sua liberdade na terra, o que significa que não frustrou sua destinação por sua culpa, será, sim, indenizado. "Esse sentimento baseia-se menos no mérito do homem do que na noção de bondade que me parece inseparável da essência divina.”271

Está também reservado ao bom o gozo da “contemplação do Ser supremo e das verdades eternas de que ele é fonte”272 . Já o mau, é pelo “lamento amargo"273 que pode esperar. O Vigário, no entanto, afirma ignorar se existem outras fontes de felicidade e de sofrimentos; para ele, as que imagina já são suficientes para que se console desta vida e o faça esperar por outra ${ }^{274}$. Além disso, também ignora se os tormentos dos maus serão eternos; ressalta que não tem a "vã curiosidade de esclarecer questões inúteis." 275 Embora diga que a sorte dos maus pouco lhe interessa, confessa ter “dificuldades para acreditar que sejam condenados a tormentos sem fim.” ${ }^{276}$ E acrescenta: "Se a suprema justiça se vinga, vinga-se já nesta vida."277 Por fim, ele deixa a Deus a decisão da punição aos maus: “Ó Ser clemente e bom! Quaisquer que sejam

\footnotetext{
${ }^{267}$ Ibidem, p.399.

${ }^{268}$ Ibidem, p.400.

${ }^{269}$ Ibidem, p.401.

${ }^{270}$ Ibidem, p.401.

${ }^{271}$ Ibidem, p.401.

${ }^{272}$ Ibidem, p.401.

${ }^{273}$ Ibidem, p.401.

${ }^{274}$ Ibidem, p.401.

${ }^{275}$ Ibidem, p.401.

${ }^{276}$ Ibidem, p.401. Aqui Rousseau afirma ter dificuldades para acreditar nos tormentos eternos; na Carta $a$ Voltaire, sobre a eternidade do sofrimento, diz com convicção: “(...) nem vós, nem eu, nem nenhum homem que pense bem de Deus jamais acreditaremos.” p. 132. Sobre essa divergência Derathé escreve: "On ne saurait contester qu'il y ait eu à cet égard une certaine évolution dans la pensée de Rousseau. » Le rationalisme de Jean-Jacques Rousseua, p.58, nota 3.

${ }^{277}$ Rousseau, J.J. Profissão de fé do vigário saboiano, p.401.
} 
teus decretos, adoro-os; se punes os maus, anulo minha fraca razão perante a tua justiça. Mas, se os remorsos desses desafortunados devem extinguir-se com o tempo, se seus males devem acabar e se a mesma paz nos espera a todos um dia, louvo-te.”278

Depois de estabelecer os artigos de fé, o próximo passo do Vigário é examinar a utilidade das verdades que conheceu; com isso, justifica porque importava conhecer tais verdades. "Depois de ter assim, da impressão dos objetos sensíveis e do sentimento interior que me leva a julgar as causas conforme as minhas luzes naturais, deduzido as principais verdades que me importava conhecer, resta-me procurar saber que máximas devo tirar delas para a minha conduta e que regras devo prescrever a mim mesmo para cumprir minha destinação na terra, conforme a intenção daquele que aqui me colocou.”279 É nesse momento que o Vigário destaca a relevância da consciência e sua superioridade frente as paixões. ${ }^{280}$

Deus existe e é bom; ele dotou o homem de liberdade e de capacidades entendimento e consciência - que permitem a este fazer o bem a outrem. Se houver, no entanto, abuso da liberdade por parte do homem, ele será punido por isso. A possibilidade de escolha deixada ao ser humano pode dar a ele o mérito no caso de agir corretamente, além do prêmio que ficará reservado na vida futura. Mas essa escolha também pode trazer conseqüências negativas se ele não souber resistir às tentações e visar o seu interesse a qualquer custo. Portanto, o homem é o responsável e fazedor de seu próprio destino: ele pode exercer seu direito à virtude, e aguardar o prêmio - a felicidade -, como pode comprar seu tormento ao agir mal.

A crença na existência de um Deus inteligente e bondoso - essa verdade que foi alcançada - é essencial na medida em que o homem sente-se vigiado, no bom sentindo, por esse Deus. O homem sabe que há alguém que olha por ele e vê tudo o que faz; assim, ele é motivado a praticar o bem: "Se faço uma boa ação sem testemunha, sei que ela é vista e registro para a outra vida a minha conduta nesta vida.”281

Já a crença na imortalidade é uma espécie de complemento do primeiro e segundo dogmas, ou artigos de fé, daí Rousseau afirmar que com a sobrevivência da alma a providência está justificada. Porque existe não só um Deus que observa o homem, mas também existe a garantia da punição àqueles que na terra se comportaram

\footnotetext{
${ }^{278}$ Idem, p.402.

${ }^{279}$ Ibidem, p.404.

${ }^{280}$ Este ponto já foi desenvolvido no capítulo I e, portanto, não iremos tratar novamente dele.

${ }^{281}$ Rousseau, J.J. Profissão de fé do vigário saboiano, p.414. Na Carta ao Senhor de Franquières, Rousseau declara: "O verdadeiro crente, que se sente em toda parte sob o olhar eterno, gosta de honrar-se diante do Céu por ter cumprido seus deveres na Terra.” P.188.
} 
mal e da felicidade àqueles que agiram bem, e, ainda, garantia da indenização aos injustiçados: “Ao sofrer uma injustiça, penso: O Ser justo que tudo rege saberá indenizar-me por isto, as necessidades de meu corpo, as misérias de minha vida tornam a idéia da morte mais suportável para mim.”282

A religião natural, portanto, contém os dogmas essenciais, isto é, estabelece somente aquilo que interessa à prática. Quanto aos dogmas que não têm não utilidade, Rousseau ou rejeita-os, explicitamente, ou mantém frente a eles uma dúvida respeitosa discutirmos este ponto no capítulo III.

\subsection{A religião em outros escritos de Rousseau}

Não são poucos os escritos de Rousseau em que ele afirma a necessidade de uma religião no Estado, e de Estado, isto é, uma religião civil. Examinaremos algumas passagens importantes de alguns desses escritos e contrastaremos, na medida do possível, com a religião proposta no Contrato Social.

No segundo Discurso, depois de ter mostrado o que teria levado os homens a se unir por um contrato e criar leis, e assim alcançar a condição ingrata a que chegaram, já que essa "nova” sociedade só deu “novos entraves ao fraco e novas forças ao rico"283, Rousseau apresenta, ainda que rapidamente, o que seria o verdadeiro contrato social ${ }^{284}$, e é aí que inclui a religião como instrumento fundamental para que a estrutura se sustente.

O corpo político legítimo é o resultado de um pacto "entre o povo e os chefes que escolhe, contrato pelo qual as duas partes se obrigam à observância das leis nele estipuladas e que formam os liames de sua união.” ${ }^{285}$ Como no Contrato Social, até

\footnotetext{
${ }^{282}$ Rousseau, J.J. Profissão de fé do vigário saboiano, p.414.

${ }^{283}$ Essa situação corresponde à que Rousseau apresenta no escrito Que L'Etat de guerre nait de l'etat social, p. 603: "Nous entrons maintenant dans un nouvel ordre de choses. Nous allons voir les hommes unis par une concorde artificielle se rassembler pour s'entre égorger et toutes les horreurs de la guerre naitre des soins qu'on avoit pris pour la prevenir. » Visando a sua segurança e conservação cada um pactua e forma uma sociedade regulada por leis. O que acontece, no entanto, é que a vida de todos, passando a pertencer ao soberano, este, por ganância, pode submetê-los a algo conforme lhe convier. Rousseau considera esta situação pior do que a que os indivíduos se encontravam antes, um estado de guerra - ainda que não o verdadeiro estado de guerra, caracterizado por outros elementos, como ele aponta neste mesmo texto.

${ }^{284}$ Rousseau, J.-J. Discurso sobre a desigualdade, p.275. O trecho contém as idéias que darão origem ao Contrato Social.

${ }^{285}$ Idem, p. 275.
} 
aqui parece tudo estar resolvido, no entanto, Rousseau introduz um elemento problemático: não pertence à natureza do pacto a irrevogabilidade. Como nota Gouhier, “a simples idéia de contrato inclui a possibilidade de abuso do poder ou de não respeito aos compromissos (...).” ${ }^{286}$ Dessa forma, “se não houvesse poder superior capaz de fazer-se fiador da fidelidade dos contratantes, nem de forçá-los a cumprir seus compromissos recíprocos, somente as partes ficariam como juízes em causa própria e cada uma delas sempre estaria no direito de renunciar ao contrato assim que achasse que a outra estivesse infringindo as condições ou desde que estas cessassem de convirlhes.”287 A religião é apontada aqui como algo que não só reforça os compromissos que foram assumidos, mas também obriga aquele que contratou a agir segundo o que foi inicialmente estabelecido, isto é, agir segundo a lei. Assim, a religião funciona como uma garantia do pacto realizado, que se traduz em cumprimento daquelas regras que expressam a vontade comum. Adotada, portanto, como medida que visa evitar o descumprimento das leis, a comunidade política correria o risco de dissolver-se caso não recorresse a ela.

Rousseau parece estar preocupado sobretudo com o abuso por parte dos magistrados $^{288}$. Se esses sentem-se no direito de renunciar à autoridade, desviando-se da lei e deixando que um interesse particular prevaleça, por que não teria o povo também o direito de fazê-lo? "Sobre tal princípio”, diz Rousseau, "parece legítimo fundamentar-se o direito de abdicar." 289 A partir do momento em que as chamadas leis fundamentais não mais guiam as ações dos magistrados, esses deixam de ser legítimos. Dessa forma, o povo não mais está obrigado a obedecer-lhes, "e como não era o magistrado, mas a lei, que constituíra a essência do Estado, cada um de direito voltaria de novo à sua liberdade natural." 290

Ora, o corpo político - legítimo - não é criado para garantir os direitos de cada indivíduo? Logo, deve-se encontrar soluções para que ele dure o maior tempo possível. No Contrato Rousseau diz que o mais importante dos cuidados do Estado é o de sua

\footnotetext{
${ }^{286}$ Gouhier, H. Les méditations métaphysiques de Jean-Jacques Roussseau, p.247: « (...) la simple idée de contrat inclut la possibilité d'abus de pouvoir ou de non-respect des engagements (...) .»

${ }^{287}$ Rousseau, J.-J. Discurso sobre a desigualdade, p. 276.

${ }^{288}$ Há uma lei específica que regulamenta a escolha e o poder dos magistrados. Esses não estão menos obrigados a obedecer às leis fundamentais, uma vez que são membros do Estado. Não é porque são encarregados de zelar pela execução de tais leis que podem eles não a observarem. Rousseau diz: "o magistrado, por seu lado, obriga-se a só utilizar o poder que lhe é confiado segundo a intenção dos que confiaram nele, a manter cada um no gozo tranqüilo do que lhe pertence e, em todas as ocasiões, a preferir a utilidade pública a seu próprio interesse.” Idem, p.275.

${ }^{289}$ Ibidem, p.276.

${ }^{290}$ Ibidem, p.276.
} 
própria conservação ${ }^{291}$. Uma solução, portanto, para a perpetuação da denominada pessoa moral é a religião, que exprime a necessidade de os governos humanos terem uma base mais sólida do que a pura razão, isto é, a necessidade a tranqüilidade pública de que a vontade divina intervenha para dar à autoridade soberana um caráter sagrado e inviolável que prive os súditos do direito funesto de dispor dela ${ }^{292}$.

Como vimos, o contrato social é em si mesmo sagrado, pois o que constitui a essência do Estado é a lei, e essa transcende o homem. Porém, como a "pura razão” não consegue dar conta de sustentar a estrutura, recorre-se a um elemento de persuasão. A autoridade que vem de fora exerce um “poder” maior e resulta mais facilmente em obediência.

No segundo Discurso, no entanto, Rousseau não fala em religião civil; parece que é à religião histórica - provavelmente o catolicismo, já que é a este que ele dirige as maiores críticas - que ele se refere, isso porque ele diz: “Ainda que a religião tivesse prodigalizado somente este bem aos homens, já bastaria para que todos devessem adorála, mesmo com seus abusos, porquanto ela poupa muito mais sangue do que aquele que o fanatismo faz correr.",293

Um texto bastante importante - na verdade uma carta - que não podemos deixar de mencionar é a Carta a Voltaire, de 1756. Se antes desse período Rousseau ainda não havia elaborado uma religião civil, limitando-se a apontar o catolicismo como religião útil ao Estado, mesmo vendo nela aspectos muito negativos, é em 1756 que “a idéia essencial da religião civil já se encontra não somente em germe, mas claramente formulada (...).”294 O trecho da Carta que deixa isso claro é o que se segue: “Gostaria, então, que houvesse em cada Estado um código moral, ou uma espécie de profissão de fé civil, contendo, positivamente, as máximas sociais as quais cada um seria obrigado a admitir, e negativamente, as máximas fanáticas as quais seria obrigado a rejeitar, não como ímpias, mas como sediciosas. Assim, toda religião que pudesse estar de acordo com o código seria admitida, toda religião que discordasse dele seria proscrita, e cada um seria livre para não ter outra a não ser o próprio código.”295 É também tendo em vista este conteúdo que alguns autores irão defender suas interpretações frente aos que

\footnotetext{
${ }^{291}$ Rousseau, J.-J. Do Contrato Social, p.48.

${ }^{292}$ Rousseau, J.-J. Discurso sobre a desigualdade, p.276.

293 Idem, p.276.

${ }^{294}$ Halbwachs, M. Du Contrat Social, p.431, Commentaire: «L’idée essentielle de la religion civile se trouve déjà non seulement en germe, mais nettement formulée (...). »

${ }^{295}$ Rousseau, J-J. Carta de J.-J. Rousseau ao Senhor de Voltaire, p.135.
} 
têm uma posição diferente acerca do capítulo sobre a religião civil contido no Contrato Social.

Se por um lado há os que vêem problema no fato de o capítulo VIII ter sido acrescentado “in extremis”296 - tratamos desse detalhe na primeira nota do capítulo 2 -, e no fim do "tratado", chegando a afirmar que Rousseau teria colocado tudo a perder com a inclusão de tal capítulo ${ }^{297}$, ou que seria (o capítulo) uma solução de última hora e , com isso, o filósofo teria mudado sua teoria ${ }^{298}$, por outro há aqueles que mostram que tais interpretações são equivocadas. Vimos que Halbwachs, por exemplo, usa como argumento o extrato da Carta a Voltaire que há pouco citamos para mostrar que tanto Masson quanto Schinz estão errados. Derathé apresenta a mesma justificativa, além de apontar o Discurso sobre a desigualdade ${ }^{299}$ como um texto em que Rousseau também faz menção à religião, e fala de sua função e relevância para o Estado, e um segundo argumento que acrescentamos na primeira nota do segundo capítulo ${ }^{300}$. Robert Derathé também utiliza, de forma a reforçar seu argumento, a opinião de Vaughan, outro estudioso de Rousseau, que diz que “(...) ‘o último capítulo do Contrato social, longe de ser um capricho passageiro, exprime em substância as opiniões acabadas do autor.’ „301

No Discurso sobre a desigualdade é o cristianismo que é chamado em apoio ao corpo político. Essa religião não está isenta dos abusos, mas estes são inferiores àquilo que ela tem de bom. No capítulo II do livro I do Manuscrito de Genebra Rousseau manifesta-se contra o suporte dos "sagrados princípios das várias religiões, cujo abuso

\footnotetext{
${ }^{296}$ Derathé, R. «La religion civile selon Rousseau », p.161.

297 « Mais où pouvait-il en parler (du 'concours de la religion dans l'établissement civil'), sans avoir l'air de se contredire et de ruiner sa thèse? » É o que diz Masson, P-M. em La religion de J.J. Rousseau (chapitre V du livre II : « Le problème de la religion civile », p. 188)

298 « (...) qu'il ait été rédigé après coup, cela n’indique en rien qu'il y ait eu un revirement chez Rousseau et que, comme l'a soutenu M. Schinz (La pensée de Jean-Jacques Rousseau), il ait décidé de faire reposer tout le corps politique sur l'unique fondement de la religion. » Halbwachs, M. Du Contrat Social, p.431, Commentaire. Derathé é da mesma opinião : « (...) il n’y a rien à retenir de l'interprétation d'Albert Schinz, lequel soutient que la religion civile est une solution de dernière heure et qu' après avoir adopté une conception rationaliste et révolutionnaire (la théorie du pacte), Rousseua aurait finalement renoué avec la tradition médiévale et théologique. " Du Contrat Social, p.1498 (nota 1, p.460), Notes et variantes.

${ }^{299}$ Na verdade Derathé atribui esse lembrete a Burgelin: « (...) l'idée même de la religion civile n’est pas une pensée de dernière heure. C'est une conception qui se trouve déjà exprimée dans la Lettre à Voltaire du août 1756 et qu'annonce aussi en 1755 un texte du Discours sur l'inégalité sur lequel M.Burgelin a heureusement attiré notre attention au colloque de Dijon.» Derathé, R. «La religion civile selon Rousseau », p.161.

${ }^{300}$ Trata-se do trecho em que mostramos que, para Derathé, o fato de o capítulo sobre a religião ter sido acrescentado no verso do capítulo sobre o Legislador, no rascunho da primeira versão do Contrato, é porque ele é um complemento natural daquele.

${ }^{301}$ Derathé, R. Du Contrat Social, Notes et Variantes, p.1499: “(...) 'le dernier chapitre du Contrat social, loin d'être un caprice passager, exprime en substance les opinions arrêtées de l'auteur'».
} 
causa tantos crimes quantos pode seu uso poupar."302 A nocividade das religiões históricas - aqui Rousseau parece não falar de nenhuma religião em específico, mas evidentemente o cristianismo está incluso - é proporcional àquilo que elas têm de positivo, e ele opta por recusá-las. Depois de mencionar que a introdução das religiões não só não seria bem-sucedida como também já causou muitos males às sociedades Rousseau dedica dois parágrafos a isso -, ele conclui que se deve deixar ao "Filósofo o exame de uma questão que o Teólogo sempre tratou em prejuízo do gênero humano.”303 É só a religião civil que pode nos trazer garantias e assegurar a tolerância, civil e religiosa, pois não se pode pensá-las separadamente - a intolerância religiosa tem, necessariamente, um efeito civil ${ }^{304}$.

Antes da formulação de um “código moral” não restava alternativa senão recorrer ao cristianismo; depois disso, passa-se a defendê-lo (o código), passa-se a defender uma “profissão de fé puramente civil” e a repudiar qualquer religião que contrarie os dogmas contidos naquela. Aceitava-se a religião que incitava o fanatismo porque tê-la com esse defeito era melhor do que não ter nenhuma. Depois que se chega a uma fórmula que não apresenta inconvenientes, ao contrário, ela é quase perfeita, torna-se impossível adotar uma outra. A pretensão de Rousseau vai além disso ainda: ele chega a afirmar, no Manuscrito de Genebra, que a religião civil "serve de base a todas as religiões do mundo" e que ela não condena nenhuma, e isso exclui o direito de apóstolos ou missionários acusarem-na de erro. ${ }^{305}$ Tal pretensão também encontra-se na Profissão de fé. Como observa Derathé, “na realidade Rousseau estava persuadido que estabelecendo a religião natural sobre bases sólidas, ele prepararia os espíritos de seu século a receber o ensinamento do Evangelho, pois em sua opinião a religião natural devia servir de fundamento à religião revelada, como ele havia afirmado a M. de Montmollin, pastor de Motiers.”306

Nas Cartas escritas da montanha, Rousseau continua afirmando a necessidade de um Estado ter uma religião: “é importante que o Estado não fique sem religião e isso

\footnotetext{
${ }^{302}$ Rousseau, J.-J. Manuscrito de Genebra, p.174.

303 Idem, p.174.

${ }^{304}$ Rousseau, J.-J. Do Contrato Social, p.144: "Na minha opinião, enganam-se os que estabelecem uma distinção entre a intolerância civil e a teológica. Essas duas intolerâncias são inseparáveis. »

${ }^{305}$ Rousseau, J-J. Du Contrat Social (Ie version), p.342: « Nul apôtre ou missionnaire n’aura droit de venir taxer d'erreur une Religion qui sert de base à toutes les religions du monde et qui n'en condamne aucune. "

${ }^{306}$ Derathé, R. « Jean-Jacques Rousseau et le christianisme », p.381: «En réalité Rousseau était persuadé qu'en établissant la religion naturelle sur des bases solides, il préparait les esprits de son siècle à recevoir l'enseignement de l'Évangile, car à ses yeux la religion naturelle devait servir de fondement à la religion révélée, comme il l’avait affirmé à $\mathrm{M}$. de Montmollin, le pasteur de Motiers. »
} 
por razões graves sobre as quais muito insisti em vários lugares (...).” 307 No entanto, se antes ele acreditava que era melhor ter uma religião mesmo que ela apresentasse aspectos prejudiciais à sociedade do que não ter nenhuma, sua opinião aqui já não é essa: “(...) valeria mais a pena não ter nenhuma religião do que ter uma bárbara e perseguidora que, tiranizando as próprias leis, contrariasse os deveres do cidadão.”308 Fiel ao que ele apresentou já na Carta a Voltaire, de 1756, mais uma vez menciona “uma religião puramente civil” ${ }^{309}$ como forma de resolver o problema - porque ela é tolerante e diz respeito unicamente aos bens terrestres.

Embora já tenhamos apresentado no tópico 1.1 os argumentos que mostram por que Rousseau rejeita o cristianismo como religião de Estado, dedicaremos mais um capítulo - o terceiro e último - a esse assunto. Com isso, queremos esclarecer melhor esse ponto e também entender a proposta da religião civil.

\footnotetext{
${ }^{307}$ Rousseau, J-.J. Lettres écrites de la montagne, p. 705: «(...) il importe que l’Etat ne soit pas sans Religion, et cela importe par des raisons graves, sur lesquelles j’ai par tout fortement insisté (...). » A tradução do corpo do texto é desta obra de Rousseau que foi traduzida para o português por Maria Constança Peres Pissarra e Maria das Graças de Souza. Não utilizamos, no entanto, a versão impressa publicada pela Editora Unesp e Educ, mas uma que foi gentilmente cedida, via on line, pelo colega Thomaz Kawauche. Isso valerá para as outras citações.

${ }^{308}$ Idem, p.705: «il vaudroit mieux encore n'en point avoir, que d'en avoir une barbare et persécutante qui, tyrannisant les Loix mêmes, contrarieroit les devoirs du Citoyen. »

${ }^{309}$ Ibidem, p. 705.
} 


\section{Capítulo III}

\section{Crítica de Rousseau ao cristianismo}

\subsection{A posição de Rousseau frente ao cristianismo}

Rousseau não somente exalta o Evangelho diversas vezes em seus vários escritos como também se auto-denomina cristão. É na Carta a Christophe de Beaumont que está contida a célebre frase: "Sou cristão, Senhor Arcebispo, e sinceramente cristão, segundo a doutrina do Evangelho. Sou cristão não como discípulo dos padres, mas como discípulo de Jesus Cristo”310 Além disso, Rousseau diferencia o “cristianismo de hoje” do cristianismo “do Evangelho" 311 , atribuindo a este último um enorme valor; distingue o “verdadeiro cristianismo”, que é “uma instituição de paz”, do “cristianismo dogmático ou teológico" ${ }^{312}$. Porém - e já sabemos disso -, do ponto de vista político, o cristianismo, mesmo o do Evangelho ou o considerado como “uma instituição de paz”, não pode ser aceito como religião do corpo político. Vejamos, portanto, os argumentos de Rousseau contidos nas Cartas escritas da montanha sobre essa recusa, uma vez que os do Contrato Social já foram examinados.

“A Religião é útil e mesmo necessária aos povos”313, afirma Rousseau na primeira das Cartas escritas da montanha. Tal afirmação é feita em um contexto em que são explicitadas diversas justificativas que têm em vista provar sua inocência. Rousseau descreve como foi acusado - injustamente e sem direito de se defender -, do que foi acusado - seus livros, Do Contrato Social e Emílio, foram condenados e queimados por terem sido considerados “ 'ímpios, escandalosos, temerários, cheios de blasfêmias e de calúnias contra a religião”314 e sua prisão foi decretada - e apresenta os argumentos daqueles que fizeram tal acusação e também os seus que, claro, tentam provar que os acusadores se equivocaram. Deter-nos-emos naqueles que mostram que a

\footnotetext{
${ }^{310}$ Rousseau, J.-J. Cartas a Christophe de Beaumont, p.72.

${ }^{311}$ Rousseau, J.-J. Do Contrato Social, p.141.

${ }^{312}$ Rousseau, J-.J. Lettres écrites de la montagne, p. 705.

313 Idem, p.695: « La Religion est utile et même nécessaire aux Peuples. »

${ }^{314}$ Ibidem, p.689: “(...) 'impies, scandaleux, téméraires, pleins de blasphèmes et de calomnies contre la Religion. »
} 
religião cristã não é conveniente como religião de Estado, mas somente como religião do gênero humano.

Jean-Jacques retoma, portanto, suas idéias acerca da religião como forma de esclarecer sua posição frente à religião cristã. Assim, sua intenção é provar que não cometeu crime algum; ao contrário, ele acreditava, com a publicação de seus escritos, estar prestando serviços à pátria: “Quanto mais me orgulhava por ter prestado serviços à Pátria, mais cruelmente fui ultrajado.”315

Rousseau distingue na religião duas partes: o dogma e a moral. Os dogmas também são divididos em duas partes, a saber, uma que, estabelecendo os princípios de nossos deveres, serve de base à moral, e a outra que, puramente restrita à fé, contém apenas dogmas especulativos. O filósofo diz que a parte da religião que deve ser conhecida pelo governante - ele ressalta que é somente neste ponto que ela (a religião) deve entrar diretamente sob sua jurisdição - é aquela concernente à moral, “isto é”, esclarece, “à justiça, ao bem público, à obediência às leis naturais e positivas, às virtudes sociais e todos os deveres do homem e do cidadão (...).”316

O que Rousseau faz é retirar da religião somente aquilo que interessa, isto é, somente conteúdos que possam contribuir para a prática das virtudes. Se o faz, no entanto, não é porque tais conteúdos são revelados ${ }^{317}$, mas porque a razão pode reconhecê-los: "Nossos prosélitos terão duas regras de fé que perfazem uma só, a razão e o Evangelho; a segunda será tanto mais imutável quanto se apoiará apenas sobre a primeira e não sobre certos fatos, os quais tendo necessidade de serem atestados, remetem a religião à autoridade dos homens." 318 Ele acredita que tudo "que nos é necessário saber para sermos santos, parece-nos claro no Evangelho: qual a necessidade de compreender o resto?’319, pergunta. Há certos ensinamentos lá contidos que nossa razão não pode alcançar, mas não devemos nos preocupar com eles uma vez que já conhecemos o suficiente para praticar o bem. "Perguntais se admitimos todo o

\footnotetext{
${ }^{315}$ Ibidem, p.688: «J'ai été outragé d'une maniere d'autant plus cruelle que je me flatois d'avoir bien mérité de la Patrie. »

${ }^{316}$ Ibidem, p.694-695: “(...) c’est-à-dire, la justice, le bien public, l’obéissance aux Loix naturelles et positives, les vertus sociales et tous les devoirs de l'homme et du Citoyen (...). »

${ }^{317}$ Na Carta a Christophe de Beaumont, p.102, Rousseau afirma: «(...) tenho como revelada toda doutrina em que reconheço o espírito de Deus.”

${ }^{318}$ Rousseau, J-.J. Lettres écrites de la montagne, p.697: "Nos prosélytes auront deux regles de foi qui n'en font qu'une, la raison et l'Evangile; la seconde sera d'autant plus immuable qu'elle ne se fondera que sur la premiere, et nullement sur certains faits, lesquels ayant besoin d'être attestés, remettent la Religion sous l'autorité des hommes. »

${ }^{319}$ Idem, p.699: "Tout ce qui nous est nécessaire à savoir pour être saints nous paroit clair dans l'Evangile; qu'avons-nous besoin d'entendre le reste ? »
} 
Evangelho; admitimos todos os ensinamentos que Jesus Cristo pregou. A utilidade e a necessidade da maior parte desses ensinamentos nos atinge profundamente e tratamos de nos conformar a eles. Alguns não estão à nossa altura, sem dúvida foram feitos para espíritos mais inteligentes do que o nosso.”320

Se Rousseau se considera cristão, ele é um cristão à sua maneira. Isso porque ele não só questiona os dogmas do cristianismo - e rejeita muitos deles, como os milagres, a Trindade, o pecado original entre outros ${ }^{321}$ - como também se recusa, explicitamente, a submeter-se à autoridade dos homens, sejam aqueles que se consideram intérpretes das palavras contidas nas Escrituras, sejam os que receberam as palavras de Deus e as transmitiram aos povos, como Moisés, por exemplo: "Peço, então, que considere ser perfeitamente normal que fatos humanos sejam atestados pelos testemunhos humanos. Não há outra forma de fazê-lo; não posso saber que Esparta e Atenas existiram a não ser porque isso me é dito por autores contemporâneos; e entre mim e um outro homem que viveu longe de mim deve haver necessariamente intermediários. Mas por que deveria havê-los entre Deus e mim, e por que deveriam ser tão remotos, exigindo por isso tantos outros? É simples, é natural que Deus tenha ido procurar Moisés para falar a JeanJacques Rousseau?”322

Havíamos anteriormente mencionado - no capítulo II - que Rousseau estabelece como critério de aceitação ou recusa de certos dogmas religiosos a razão humana. Portanto, se determinado dogma é conforme a razão, ele é admitido como verdadeiro; se, no entanto, é contrário a ela, não deve ser admitido. Mas há também coisas no Evangelho que, mesmo ultrapassando a razão, o autor prefere manter em dúvida respeitosa, exatamente porque não pode alcançá-las. Nas Cartas da Montanha ele afirma: “Muitas coisas no Evangelho ultrapassam nossa razão, até mesmo a chocam, entretanto nós não as rejeitamos. Convencidos da fraqueza de nosso entendimento, sabemos respeitar aquilo que não podemos conceber quando a associação do que concebemos nos faz julgá-lo superior às nossas luzes.”323 Rousseau expressa idéia

\footnotetext{
${ }^{320}$ Ibidem, p.699: “Vous nous demandez si nous admettons tout l'Evangile; nous admettons tous les enseignemens qu’a donné Jésus-Christ. L’utilité, la nécessité de la plupart de ces enseignemens nous frape et nous tâchons de nous y conformer.Quelques-uns ne sont pas à notre portée; ils ont été donnés sans doute pour des esprits plus intelligens que nous. »

${ }^{321}$ Não examinaremos aqui os argumentos que Rousseau desenvolve contra os dogmas mencionados; isso tornaria o trabalho muito extenso. Acreditamos que dentro da proposta de pesquisa que se apresentou podemos nos limitar ao que foi analisado.

${ }^{322}$ Rousseau, J.-J. Carta a Christophe de Beaumont, p.97.

${ }^{323}$ Rousseau, J-.J. Lettres écrites de la montagne, p.699: “Beaucoup de choses dans l'Evangile passent notre raison, et même la choquent; nous ne les rejettons pourtant pas. Convaincus de la foiblesse de notre
} 
semelhante no Emílio: «(...) o Evangelho está cheio de coisas inacreditáveis, de coisas que repugnam à razão e que nenhum homem sensato pode conceber ou admitir. O que fazer em meio a todas essas contradições? Continuar sendo modesto e circunspecto, meu filho; respeitar em silêncio o que não poderíamos nem rejeitar, nem compreender, e humilhar-nos diante do grande Ser que é o único a saber a verdade.”’324 Sua posição neste sentido não é muito clara, pois ele parece abrir uma exceção. Primeiro diz que tudo o que é contrário à razão deve ser rejeitado, e as coisas do Evangelho que “chocam” a razão e até mesmo lhe "repugnam” não podem ser admitidas mas também não podem ser rejeitadas e deve-se ter uma atitude com relação a elas de "dúvida respeitosa"? ${ }^{325}$

O cristianismo, uma vez que contém dogmas que contrariam a razão e, além disso, dogmas que nada contribuem para a boa constituição do Estado - Rousseau menciona os dogmas da Trindade e do pecado original ${ }^{326}$ - não pode ser aceito como religião de Estado. Mas Rousseau não se limita a esses argumentos. Vejamos, então, quais são os outros.

Ao final da primeira das Cartas escritas da montanha, Rousseau reforça sua recusa da religião cristã “como parte constitutiva do sistema de legislação" 327 apresentando as seguintes justificativas: querer fazer do cristianismo uma religião nacional seria cometer uma falha não só contra o Estado, mas também contra a própria religião. Os que fizeram isso “afastaram-se do espírito de Jesus Cristo, cujo reino não é deste mundo, e, misturando aos interesses terrestres os da religião, contaminaram sua pureza celeste, transformando-a em arma dos tiranos e instrumento dos perseguidores. Não menos feriram as máximas sãs da política, pois, no lugar de simplificar a máquina do governo, tornaram-na mais complexa, dando-lhe engrenagens estranhas e supérfluas e, submetendo-a a dois móbiles diferentes, freqüentemente contrários, provocaram as tensões percebidas em todos os estados cristãos nos quais se inseriu a religião no

entendement, nous savons respecter ce que nous ne pouvons concevoir, quand l'association de ce que nous le fait juger supérieur à nous lumieres. » O grifo é nosso.

${ }^{324}$ Rousseau, J.J. Profissão de fé do vigário saboiano, p.440. Os grifos são nossos.

${ }^{325}$ Sobre esse ponto Derathé, em Le rationalisme de Jean-Jacques Rousseau, página 57, nota 1, faz a seguinte observação: “A vrai dire, dès qu’on pénètre dans le détail de sa croyance, on s’aperçoit qu’il n’y a pas en réalité pour Rousseau de frontière bien nette entre les choses qu'il faut rejeter parce qu'elles sont absurdes et celles qu'on doit 'respecter' sans les rejeter ni les admettre parce qu'elle sont seulement incompréhensibles. »

${ }^{326}$ Rousseau, J-.J. Lettres écrites de la montagne, p. 705: « (...) comment le mystère de la Trinité, par exemple, peut-il concourir à la bonne constitution de l'Etat, en quoi ses membres seront-ils meilleurs Citoyen quand ils auront rejetté le mérite des bonnes oeuvres, et que fait au lien de la société civile le dogme du péché originel ? »

${ }^{327}$ Idem, p.704: “(...) comme partie constitutive dans le systême de la Législation (...).» 
sistema político.” ${ }^{328}$ Transformar o cristianismo, que é, em seu princípio, uma religião universal $^{329}$, em religião nacional, comprometeria não somente o Estado mas o cristianismo mesmo. O prejuízo para a religião seria subtrair seu caráter transcendente; para o Estado seria criar uma contradição no que diz respeito à moral ${ }^{330}$. A religião cristã centra-se na salvação futura; o Estado, ao contrário, está preocupado com a salvação terrena. "Como aquilo que distancia os corações da terra nos daria mais interesse pelo que ali se faz? Como é que aquilo que unicamente nos ocupa com uma outra Pátria nos prenderia mais ainda a esta?’331

O que deve ser incitado no indivíduo é antes o amor a pátria do que o amor à humanidade - papel do cristianismo ${ }^{332}$. As relações devem ser estreitas para que o vínculo social seja fortalecido. Se por um lado a religião cristã não pode fazer parte da constituição do Estado, por outro Rousseau estabelece-a como “a melhor para o gênero humano”333 . “A religião cristã é, pela pureza de sua moral, sempre boa e sã no Estado, desde que ela não faça parte de sua constituição, desde que ela aí seja admitida unicamente como religião, sentimento, opinião, crença. Mas, como lei política, o cristianismo dogmático é uma má instituição.”334

Considerar o cristianismo como a melhor religião para o gênero humano parece ser uma estratégia de Rousseau para escapar das acusações que recebeu. Implicitamente, ele já havia descartado essa religião; agora parece querer dar a ela alguma utilidade.

\footnotetext{
${ }^{328}$ Ibidem, p.704: “Ils se sont écartés de l'esprit de Jésus-Christ dont le regne n’est pas de ce monde, et mêlant aux intérêts terrestres ceux de la Religion, ils ont souillé sa pureté céleste, ils en ont fait l’arme des Tyrans et l'instrument des persécuteurs. Ils n'ont pas moins blessé les saines maximes de la politique, puisqu'au lieu de simplifier la machine du Gouvernement, ils l'ont composée, ils lui ont donné des ressorts étrangers superflus, et l'assujetissant à deux mobiles différens, souvent contraires, ils ont causé les tiraillemens qu'on sent dans tous les Etats chrétiens où l'on a fait entrer la Religion dans les systême politique. »

${ }^{329}$ Ibidem, p.704.

${ }^{330}$ Vale a pena aqui reproduzirmos uma passagem da Carta a Christophe de Beaumont em que Rousseau, ao responder aos ataques do arcebispo de Paris, escreve: "Custa tão pouco seguir uma doutrina, e custa tanto praticar a moral, que, aderindo ao lado mais fácil, a falta das boas obras é compensada pelo mérito de uma grande fé.” (p. 83). A moral cristã coloca a fé acima de qualquer coisa, enquanto Rousseau pensa uma religião que tenha como objetivo a prática dos deveres.

${ }^{331}$ Ibidem, p.704: "Comment ce qui détache les coeurs de la terre nous donneroit-il plus d'intérêt pour ce qui s'y fait? comment ce qui nous occupe uniquement d'une autre Patrie nous attacheroit-il davantage à celle-ci ? "

${ }^{332}$ Aliás, Rousseau afirma, em uma nota de rodapé, contida, na edição utilizada, na página 706 - indicada por dois asteriscos - , que o patriotismo e a humanidade são "deux vertus incompatibles dans leur énergie, et surtout chez un peuple entier.” E continua: « Le Législateur qui les voudra toutes deux n'obtiendra ni l'une ni l'autre : cet accord ne s'est jamais vu; il ne se verra jamais, parce qu'il est contraire à la nature, et qu'on ne peut donner deux objets à la même passion. »

${ }^{333}$ Rousseau, J-.J. Lettres écrites de la montagne, p.707: “(...) la meilleure pour le genre humain. »

${ }^{334}$ Idem, p.706: "La Religion Chrétienne est, par la pureté de sa morale, toujours bonne et saine dans l'Etat, pourvu qu'on n'en fasse pas une partie de sa constituition, pourvu qu'elle y soit admise uniquement comme Religion, sentiment, opinion, croyance; mais comme Loi politique, le Christianisme dogmatique est un mauvais établissement. »
} 
Sabemos que Jean-Jacque reprova a postura cosmopolita, e uma religião do gênero humano tem o mesmo princípio que o cosmopolitismo: o amor à humanidade. $\mathrm{O}$ autor declara no capítulo II do livro I do Manuscrito de Genebra: "Concebamos a sociedade geral segundo nossas sociedades particulares, o estabelecimento das pequenas repúblicas faz-nos sonhar com a grande, e só começamos propriamente a tornar-nos homens depois de ter sido cidadãos. Por onde se vê o que se deve pensar daqueles pretensos cosmopolitas que, justificando seu amor à pátria pelo amor ao gênero humano, se gabam de amar a todo mundo a fim de ter o direito de não amar a ninguém.” 335

É depois de apresentar os motivos pelos quais recusa o cristianismo como religião do corpo político que Rousseau retoma a proposta da religião civil. JeanJacques coloca o seguinte o problema: o que deve fazer um Legislador se o Estado não pode ficar sem religião mas ao mesmo tempo esta não pode ser a religião cristã? Responde dizendo que deve ser estabelecida uma religião puramente civil "na qual, contendo os dogmas fundamentais de toda boa religião, todos os dogmas verdadeiramente úteis à sociedade, seja universal, seja particular, omita todos os outros que possam interessar à fé, mas de forma alguma ao bem terrestre, único objeto da legislação.”336

Pretendíamos com este capítulo somente reforçar os argumentos de Rousseau que apontam o cristianismo como religião inadequada ao Estado, pois nas Cartas da montanha ele não desenvolve nada muito além do que já está contido no Contrato Social.

\footnotetext{
${ }^{335}$ Rousseau, J-.J. Manuscrito de Genebra, p.175.

${ }^{336}$ Rousseau, J-.J. Lettres écrites de la montagne, p.705: “(...) dans laquelle renfermant les dogmes fondamentaux de toute bonne Religion, tous les dogmes vraiment utiles à la societé, soit universelle soit particuliere, il omette tous les autres qui peuvent importer à la foi, mais nullement au bien terrestre, unique objet de la Législation (...). »
} 


\section{Conclusão}

Poderíamos ter examinado a função da religião civil sem retomar os aspectos mais conhecidos e mais estudados do pensamento político de Rousseau, mas, nesse caso, teria sido muito mais difícil explicar sua relevância. Diante do cenário que tentamos expor, acreditamos ter mostrado por que a religião é uma peça indispensável - enfim, por que Rousseau é categórico ao afirmar a importância da religião no Estado.

Recapitulando: a causa do mal dos homens está nas relações sociais. É preciso, portanto, repensar e reconstruir essas relações, para que seja garantida aos indivíduos uma condição em que todos possam viver livremente, isto é, de acordo com sua natureza, sem que uns dependam do arbítrio de outros. Não se trata, como alguns pretenderam, de um retorno ao estado de natureza, o que seria absurdo e sem sentido ${ }^{337}$. Trata-se, ao contrário, de criar uma nova sociedade moldada segundo certos princípios e enquadrada em certos limites. Rousseau não tem a ilusão de um retorno a um estado anterior a toda experiência social e ao desenvolvimento da razão. O homem corrompido é um homem socializado - e esta é a condição daqueles homens à beira do desastre mencionados no início do capítulo VI do livro I do Contrato Social. A esperança de salvação só pode estar, portanto, na reconstrução da vida coletiva.

Rousseau constrói o modelo dessa nova sociedade sobre uma base puramente racional. O empreendimento é descrito nos termos de um cálculo: “ 'Encontrar uma forma de associação que defenda e proteja a pessoa e os bens de cada associado com toda a força comum, e pela qual cada um, unindo-se a todos, só obedece contudo a si mesmo, permanecendo assim tão livre quanto antes”’ ${ }^{338}$. Esse resultado torna-se possível porque "cada um, dando-se a todos, não se dá a ninguém, e, não existindo um associado sobre o qual não se adquira o mesmo direito que se lhe cede sobre si mesmo, ganha-se o equivalente de tudo que se perde, e maior força para que se conservar o que se tem”339. A cada concessão, portanto, equivale uma aquisição, mas o resultado, surpreendentemente, não é igual a zero, a soma algébrica dos elementos anteriormente existentes. É maior, porque cada qual ganha mais força para se defender.

\footnotetext{
${ }^{337}$ Rousseau, J-J. Discurso sobre a desigualdade, p.295: "Pois então será preciso destruir as sociedades, suprimir o teu e o meu, e voltar a viver nas florestas com os ursos? É essa uma conseqüência à moda de meus adversários, que prefiro antes prevenir do que possibilitar-lhes a vergonha de formulá-la.”

${ }^{338}$ Rousseau, J-J. Do Contrato Social, p.32.

${ }^{339}$ Idem, p.33.
} 
Cada um dos indivíduos põe a sua pessoa e o seu poder sob a direção suprema da vontade geral. A vontade, que é uma faculdade humana, trabalha em conjunto com uma outra faculdade, o entendimento. Este último apresenta à vontade o objeto - produto da operação que foi realizada -, que é o bem comum, captado da natureza das coisas. A lei, que é expressão dessa vontade, tem, portanto, um objeto comum aos indivíduos. Assim, a liberdade individual passa a ter esse limite, e é somente tal limite que garante uma sociedade justa. Mas o trabalho de reconstrução - e este é um ponto fundamental para a interpretação do pensamento de Rousseau - não se esgota na criação de estruturas externas ao indivíduo, à reforma institucional, portanto.

Certo, o Contrato Social, como indica o subtítulo, trata dos princípios do direito político. A eficácia desses princípios, no entanto, não depende apenas de uma sujeição mecânica dos interesses privados a uma ordem comum construída racionalmente e sustentada por um sistema repressivo.

Numa sociedade bem constituída, é preciso que as leis sejam poucas e simples e que a obediência dependa apenas ocasionalmente da repressão. Nenhuma sociedade pode durar muito tempo, nem proporcionar uma vida livre e satisfatória, quando as condições de coexistência só se impõem pela vigilância constante e pelo risco permanente do castigo. Esse quadro seria ainda menos concebível quando se pensa numa cidadania ativa, nos moldes daquela encontrada na vida republicana da antiguidade, o ideal sempre evocado por Jean-Jacques.

A introdução de uma ordem religiosa nessa construção teórica não contradiz sua base racional, porque o seu papel é reforçar a disposição de cumprimento das leis. Rousseau procura uma religião que acrescente força às leis, tornando o respeito à legalidade menos dependente do exercício da força repressiva. Isso se torna possível na medida em que se robustece o amor aos deveres, levando o indivíduo a agir espontaneamente segundo as normas sociais.

A violação às leis, é certo, implica punição. Aquele que aderiu ao pacto precisava ter uma garantia de que todos agiriam tendo em vista o interesse comum, pois caso contrário não veria vantagem no contrato. A ameaça da punição pode levar o indivíduo a agir bem; porém, é necessário que haja um motivo ainda mais forte para que ele o faça, e tal motivo é o amor da ação correta, nele fortalecido por tudo aquilo que alimenta a sociabilidade e, na dimensão política, o amor da pátria. A formação dessas qualidades depende não só da educação no interior de cada família, mas também de uma pedagogia social adequada às condições de cada povo. Nas Considerações sobre o 
Governo da Polônia, Rousseau se estende na exposição de como se pode realizar esse trabalho pedagógico, tomando como exemplo a ação dos grandes legisladores da antiguidade. As instituições nacionais “que formam o gênio, o caráter, os gostos e os costumes de um povo, que o fazem ser ele e não outro" ${ }^{340}$, não são apenas sistemas de normas e de castigos, mas instrumentos que moldam a disposição dos indivíduos e os predispõem a agir segundo certos padrões. A construção das virtudes, da sociabilidade e da identidade coletiva é o grande tema que unifica o Emílio, o Contrato e as Considerações sobre o Governo da Polônia.

No Contrato, Rousseau realça o papel de um elemento particularmente eficaz na formação do espírito coletivo, a religião civil. O critério que regula a sociedade e que garante a liberdade dos indivíduos é o bem comum. Mas, para alcançá-lo, é exigida uma capacidade que muitos ainda não desenvolveram nos estágios iniciais da reforma ${ }^{341}$. O Legislador cumpre a função de identificar esse bem comum e de apontá-lo ao povo, mas, como não pode convencer esse povo, ele recorre à religião para persuadi-lo. Mas, mesmo quando o indivíduo se torna capaz, pelo exercício da razão, de identificar o bem comum, a sujeição do interesse privado ao interesse geral não é assegurada. É necessário, ainda, que a vontade instruída pela razão se sobreponha à força das paixões. É papel da religião atuar como reforço da virtude nesse embate.

A religião tem força não só pelo respeito que impõe, mas também porque promete sanção e oferece recompensas numa vida futura. Segundo Rousseau, a lei pode transformar uma sociedade, criando hábitos que se infiltrem nas almas dos homens e os convertam em bons cidadãos. Mas, como eles nem sempre são capazes de enxergar as vantagens das leis, é preciso que sejam persuadidos, e a idéia de um Deus bom, justo e poderoso é essencial nesse processo. Além disso, mesmo que sejam capazes de ver aquelas vantagens, é necessário que sejam estimulados a agir de acordo com a razão. A repressão legal pode contribuir para esse processo, mas uma boa sociedade, vale a pena repetir, não pode ter como base apenas o medo da punição. Quanto mais necessária a repressão, mais distantes se encontram os homens do império das virtudes características do Estado vigoroso e bem constituído. No modelo de sociedade exemplar mencionado na dedicatória do Discurso sobre a Desigualdade, a ordem é garantida principalmente pelo amor da pátria e pela transparência das relações entre os indivíduos.

\footnotetext{
${ }^{340}$ Rousseau, J.J. Considerações sobre o Governo da Polônia e sua Reforma Projetada, 230.

${ }^{341}$ Se não são capazes de conhecer o bem comum, também não podem amá-lo, já que só se pode amar aquilo que se conhece. Portanto, a consciência também não tem efeito.
} 
O Estado concebido por Rousseau, no Contrato, necessita, como tantos outros necessitaram, no passado, de uma religião - mas essa deve ser puramente civil, com dogmas muito simples, que incitem a prática às virtudes. Quem dela descrer será considerado insociável, e não ímpio. Esta distinção é o único fundamento da intolerância admita por Jean-Jacques Rousseau. A aceitação ou rejeição da religião civil não é uma questão privada, relativa somente à relação entre o indivíduo e à divindade, mas um assunto de interesse coletivo, porque dessa decisão depende, segundo o autor do Contrato, a capacidade de cada um de cumprir plenamente os requisitos da cidadania. 


\section{Bibliografia}

Obras de Rousseau:

Oeuvres Complètes de Jean-Jacques Rousseau. Ed.Bernard Gagnebin e Marcel Raymond. Paris : Gallimard, 1959-1995. 5 volumes (Col. "Bibliothèque de la Pléiade)

ROUSSEAU, J.J. Carta a Christophe de Beaumont e outros escritos sobre a religião e a moral. São Paulo: Estação Liberdade, 2005.

Considerações sobre o Governo da Polônia e sua Reforma Projetada.

São Paulo: Editora Brasiliense, 1982.

Considerações sobre o Governo da Polônia e sua Reforma Projetada.

São Paulo: Imprensa Oficial, UNB e Ipri, 2003.

Discurso sobre a origem e os fundamentos da desigualdade entre os homens. São Paulo: Abril ( Col. Os Pensadores), 1978.

Discurso sobre as ciências e as artes. São Paulo: Abril (Col. Os Pensadores), 1978.

Do Contrato Social. São Paulo: Abril (Col. Os Pensadores), 1978.

Lettres à Voltaire. In: Correspondance Générale de J.-J. Rousseau. Ed.

Theophile Dufour. Paris: Armand Colin, 1924-1934. T.II

Emílio ou da Educação. São Paulo: Martins Fontes, 2004.

Ensaio sobre as origens da língua. São Paulo: Abril (Col. Os

Pensadores), 1978.

Projeto de Constituição para a Córsega. São Paulo: Imprensa Oficial,

UNB e Ipri, 2003.

Tratado Sobre a Economia Política. São Paulo: Imprensa Oficial,

UNB e Ipri, 2003.

Outras de apoio:

BARROS, A. R. A teoria da soberania de Jean Bodin. São Paulo: Unimarco, 2001.

BODIN, J. Les six livres de la Republique (livro I capítulos VIII ao X. p.179-341).

Paris: Fayard, 1986.

BRAVO, FRANCISCO Menón: La ontologia de la definicion en el Ménon. In: Hypnos, n.13, p.40-52, 2004.

CASSIRER, ERNEST A questão Jean-Jacques Rousseau, São Paulo: Unesp, 1999. 
L’unité dans l’oeuvre de Rousseau. In: Pensée de Rousseau.

Paris: Éditions du Seuil, 1984.

A Filosofia do Iluminismo. Campinas: Editora Unicamp, 1994.

COTTA, SERGIO. «Théorie religieuse et théorie politique chez Rousseau ». In: Annales de Philosophie PolitiqueI. Paris : PUF, p.171-194, 1965.

COULANGES, F. de A cidade antiga. Rio de Janeiro: Ediouro, 2004.

DENT, N.J.H. Dicionário de Rousseau. Rio de Janeiro: Jorge Zahar, 1996.

DERATHÉ, R. Jean-Jacques Rousseau et la science politique de son temps. Paris: Librairie Philosophique J. Vrin, 1995.

"Jean-Jacques Rousseau et le christianisme ». In: Revue de Métaphysique et de Morale, Anée 53, n. 1, p. 379-414,1948.

«La religion civile selon Rousseau ». In: Annales de la société J.J.Rousseau, T.XXXV, p. 161-180, 1963.

Le racionalisme de Jean-Jacques Rousseau. Paris : Presses Universitaires de France, 1948.

«Les rapports de la morale et de la religion chez Jean-Jacques Rousseau ». In : Revue Philosophique, p.143-173, 1949.

“L’homme selon Rousseau”. In: Pensée de Rousseau. Paris: Éditions du Seuil, 1984.

DIDEROT, D. Direito Natural. In: Verbetes políticos da Enciclopédia. São Paulo: Editora Unesp, Discurso Editorial, 2006.

DURKHEIM, E. Montesquieu et Rousseau précurseurs de la sociologie. Paris: Librairie Marcel Rivière et Ci, 1953.

As formas elementares da vida religiosa (O sistema totêmico na Austrália) Introdução e Conclusão, Tradução de Carlos Alberto Ribeiro de Moura, Col. Os Pensadores, 2. ed. São Paulo, Abril Cultural, 1983.

ÉDOUARD PISTERS S. M. La Nature des Formes Intencionnelles d'après Saint Thomas d'Aquin (Introdução e Primeira Parte : p.7-31). Paris : Éditions Pierre Bossuet, 1933.

EGÍDIO ROMANO Sobre o poder eclesiástico. Petrópolis: Vozes, 1989.

FONSECA JUNIOR, GELSON Rousseau e as Relações Internacionais. Imprensa Oficial, UNB e Ipri, 2003.

GOLDSCHMIDT, VICTOR. Anthropologie et politique: les principes du système de Rousseau. Paris: J. Vrin, 1974 
«Individu et communauté chez Rousseau ». In : Pensée

de Rousseau. Paris: Éditions du Seuil, p.147-161,1984.

GOUHIER, HENRI. Méditations métaphysiques de J.J. Rousseau. Paris : Librairie Philosophique J. Vrin, 1984.

GOYARD-FABRE, S. Essai. In: L'État de Guerre / Fragments sur la guerre. Babel, p.43-83, 2000.

HALBWACHS, M. “Introduction”. In: ROUSSEAU, Jean-Jacques. Du contrat social. Aubier: Éditions Montaigne, 1943.

HERRERA, D. A. Participación y Analogía en la fundamentación del Derecho según Santo Tomás de Aquino.

HOBBES, THOMAS Leviatã. São Paulo: Abril (Col. Os Pensadores), 1977.

HÖFFDING, H “Rousseau et la religion”. In : Revue de Métaphisique et de Morale, p. 275-293, 1912.

JAEGER, W. Paidéia - A formação do homem grego. São Paulo: Herder, 1936.

KUNTZ, R. N. Teoria Política de Rousseau. Tese de mestrado apresentada à Faculdade de Filosofia, Letras e Ciências Humanas da Universidade de São Paulo, em dezembro de 1970.

LOCKE, JOHN Dois Tratados sobre o governo. São Paulo: Martins Fontes, 1998.

LEBRUN, GÈRARD. “Contrat social ou Marché de dupes?”. Manuscrito, Campinas, v. III, n. 2, 1980.

LIBERA, ALAIN DE La querelle des universaux - De Platon à la fin du Moyen Age (p. 51-59). Paris: Éditions du Seuil, 1996.

LUTERO, MARTINHO Da liberdade do cristão. São Paulo: Fundação Editora da Unesp, 1998.

MARSÍlIO DE PÁDUA O Defensor da Paz. Rio de Janeiro: Vozes, 1991.

MASSON, P.M. La religion de J.J. Rousseau. Paris: Hachette, 1916.

OCKHAM, G. Brevilóquio sobre o principado tirânico. Petrópolis: Vozes, 1988.

PARODI, D. « La philosophie religieuse de J.J-Rousseau ». In : Revue de Métaphisique et de Morale, p. 295-320, 1912.

PLATÃO Eutifron. Paris: Traduction de Victor Cousin, 1822

Menão. Rio de Janeiro: Ed.PUC-Rio; Loyola, 2001.

ROSS, W. D. Teoría de las ideas de Platón (parte II, p. 26-38). Madrid: Cátedra (Col. Teorema), 1993. 
SALINAS FORTES, L.R. Paradoxo do Espetáculo. São Paulo: Discurso Editorial, 1997.

SCHINZ, A. La pensée de Jean-Jacques Rousseau. Paris: Librairie Félix Alcan, 1929.

STAROBINSKI, J. A transparência e o obstáculo. São Paulo: Companhia das Letras, 1991.

STRAUSS, L. Droit naturel et histoire. Paris: Flammarion, 1986.

“L’ intention de Rousseau”. In: Pensée de Rousseau. Paris: Éditions du Seuil, 1984.

TOMAS DE AQUINO Suma de Teologia (1 ${ }^{\text {a }}$ Parte: Questão 22, Artigos 1 e 2; Questão 79, Artigos 11 a 13; Questão 82, Artigos 3 e 4; Questão 103, Artigos 1 e $5.1^{\text {a }}$ Parte da $2^{\text {a }}$ Parte: Questão 8, Artigo 1; Questão 9, Artigo 1; Questão 17, Artigo 1; Questão 30, Artigo 3; Questão 90, Artigos 1 a 4; Questão 91, Artigos 1,2 e 6; Questão 93, Artigos 1 a 6. $2^{\text {a }}$ Parte da $2^{\text {a }}$ Parte: Questão 57, Artigo 1). São Paulo: Loyola, Volumes II, III, IV e VI, 2005.

Suma de Teologia [Questão 8, Artigo 1, corpo do artigo (parte)].

Uberlândia: Udufu, 2004. 